\title{
The Religious Development of the Negro in Virginia
}

\section{A DISSERTATION}

Submitted to the Faculty of the University of Virginia in Partial Fulfillment of the Requirements for the Degree of Doctor of Philosophy

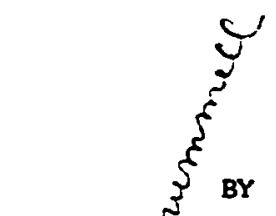

JOSEPH B.'EARNEST, Jr., M. A. Noifolk $V a$.

THE MOCHE COMPANY, PRINTERS

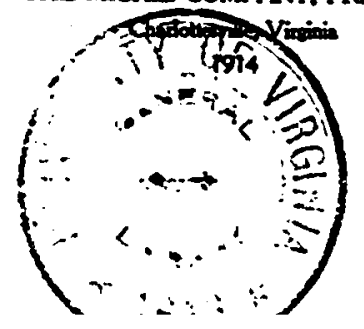




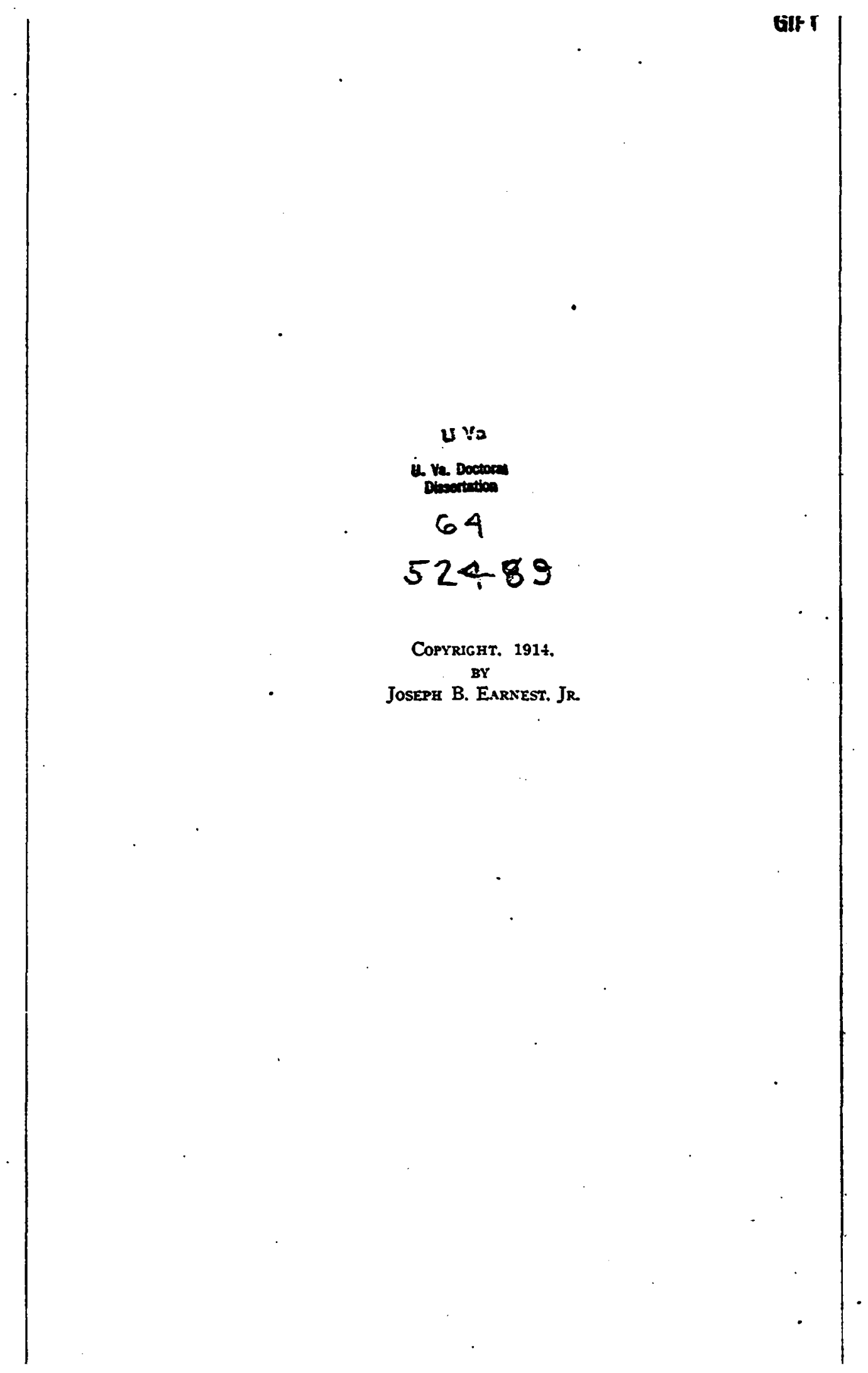




\section{PREFACE.}

Virginia is one of the richest fields for historical research; the Negro question is one of the most pressing of our day; the religious is the most neglected phase of the great Negro problem. It could not seem strange therefore that this study should be undertaken in the face of such a challenge.

It is a fact, not without significance. that of the four dissertations issued from the School of History at the Lniversity of Virginia, two have had as their subject, the Negro. To the influence of Professor R. H. Dabney, we ascribe this interest. Dr. J. P. McConnell's dissertation, "Negroes and Their Treatment in Virginia from 1865 to $186 \overline{7}$, U. Va. 1905, is an intensive study of a strategic period in the life of the Negro, and embraces legal. political, social and religious considerations. This present dissertation, in contradistinction to his, is an intensive study of one phase of the Negro's life in Virginia-the religious-from the date of the landing in America up to the present. The effort is conscientiously made to hew to that mark. Apologists and excoriators might shout the praises of the Negro or hurl at him verbal damnation, yet Time will record the amelioration of his rcligious condition while in America, as one of the proudest achievements of Anglo-Saxon Missionary energies. In the South, Virginia has taken a prominent part in this transformation or spirit-worshipping savages into worshippers of one God, men and women who sometimes show characters as deeply devout and conscientious as can be found anywhere. Just what factors and influences brought this about I shall endeavor to indicate.

In this study nearly a thousand letters have been sent to prominent white citizens, prominent Negro citizens and Negro preachers. The endeavor was to secure evidence from every part of the State. About seventy-five per cent of these letters were carefully answered, which might be interpreted to indicate the sensitive state of public opinion on the subject. Of course, no one could expect that 100 per cent of such letters would be answered. Human nature is still human. Even in private conver- 
sation a few Negroes evidently invoked the principle, "Doan tell the white man nuffin ;" and in spite of an expression of my intention to strive to deal fairly with their much maligned race a few could not be convinced. Several white men answering the letters sent to them frankly confessed that they knew absolutely nothing about the religious life of the Negro and dared not venture any opinion. If these letters served to stir the thoughtful of either race to consider the tremendous significance of the problems presented, they will not have been sent in vain.

The more thoughtful elements in both races are anxious for some adjustment in the near future by which the charity of the more highly developed race can aid in the uplift of the more unfortunate race. That a religious oversight was the fixed policy up to the close of the War of Secession, I believe I shall be able to demonstrate. It is also true that the history of the years since then exhibit the struggles, both successful and unsuccessful, of a goodly number of dark-skinned men, single-handed, often burdened by false friends, patiently wrestling with the problem of racial uplift in things religious.

No person who has undertaken to write a monograph has had better reason to be thankful to friends for invaluable advice and aid in collecting data, than I have. It almost seems to be their work instead of my own. Dr. R. H. Dabney, professor of History at the University of Virginia, suggested the subject and has very frequently counseled me with his mature judgment. I acknowledge to him, first of all, my debt of gratitude. Among others who have laid upon me by their kindnesses, obligations which I fear I shall never be able to repay fully, are Mr. John S. Patton, Librarian, and Miss M. L. Dinwiddie, Assistant Librarian, University of Virginia; Mr. Earl G. Swem, Assistant Librarian, and Dr. H. G. Eckenrode, Archivist, Virginia State I.ibrary; Mr. C. H. Ryland, Secretary and Librarian, Rirhmond College, and Librarian of Baptist Historical Collection, Richmond, Va.; Messrs. J. G. and Hugh L. Morrison, Chief Assistants in Reading Room, Library of Congress; Mr. Wm. Anthony Aery, 'Press Service Manager, and Misses Leonora E. Herron and Mary E. Lane, Librarian and Assistant Librarian, Hampton Normal and Industrial School; Mr. Edward C. Wilson, principal of Friends' School, Baltimore, Md, and Mr. 
Kirk Brown, Keeper of Friends ${ }^{\circ}$ Records at Park Avenue Meeting House, Baltimore, Md.

It would constitute a book in itself should all the individuals, white and colored, be enumerated that have so freely given time and information to this work. I am deeply grateful to these many benefactors. It would be impossible, however, to fail to mention the names of the following gentlemen, for signal services rendered me: Dr. Lyon G. Tyler, President William and Mary College, and Rev. E. Ruffin Jones, Rector of Bruton Parish Church, Williamsburg, Va., Dr..C. H. Hovey, President Virginia Union University, Richmond, Va., and Hon. Rosewell Page, Hanover County, Va.

It seems that it is not the custom to dedicate such studies as this to anyone. Were it the custom, this would unhesitatingly be dedicated to my mother, whose tenderest love and unbounded patience early taught me to see the good in everybody and in everything.

University, Va.,

J. B. E., JR.

June $17,19 I_{4}$. 


$$
\mid 1
$$




\section{The Religious Development of the Negro in Virginia.}

\section{INTRODLCTION.}

If the Negro is more susceptible to any other influence than to religious fervor we fail to know it. Whether propitiating the anger of enraged spirits in his African home, or in the ecstasy of narrating in America the details of a harrowing religious experience at the time of his conversion, he is instinctively religious. Some think he is too religious; others that he is not religious at all; we believe that he is religious and is improving religiously.

It seems that an average Negro is much sought after in this day for purposes of study. Where is an average Negro? One might point out a man like Major R. R. Moton, commandant at Hampton Normal School, and the world acknowledges his worth, yet he is not average; he is nearer the ideal Negro. One sees elsewhere ragged, besotted, cursing black men bringing disgrace upon themselves and their race. Neither are they average; they are below normal. Objections are raised to individual characters as fast as they are presented. One is uppish after an education in the North; another is too backward for refusing an education in the South: one is too temperate to be average; another is too intemperate: one is too pert, another is too submissive: one is too ambitious, another lacks ambition. This bewildering list of pro's and con's could be prolonged indefinitely, since we insist not only upon the possession of many qualities to satisfy ourselves, but also upon the fact that an average Negro from our viewpoint need not necessarily be an average Negro from the Negro's viewpoint. It is likely that our estimates will differ. Whom shall we have in mind as we trace the Negro's religious development in Virginia? It would have been delightful if in this study an average Negro could 
have been selected in each decade and by simply watching him move and have his being, we could have thus traced the religious development in Virginia from the arrival of the Dutch ship to this present day. But the world is all different from such a theoretical dream, and in absence of an average Negro we shall strive to indicate the race's religious evolution in Virginia.

Very briefly, we must see what the Negro brought into America religiously before we can appreciate this development. There are no contemporary records of what the Negro did religiously before 1619. We have to rely on observations of travelers of a later day and reports of students and missionaries who have lived among them. Even though R. E. Dennett has written a book entitled "At the Back of the Black Man's Mind," we can be very sure that no white man has ever known what is, or was, back there. It is one of the inscrutable things of the universe. We . can imagine, surmise, guess, but knowledge on that subject is forbidden to the white man. That there was something in the back of the black man's mind religiously before he came to America seems likely to be true. From what we can gather, it was a very disappointing something-yet it was something. The surest thing about their religion was the fact that it was a very low form, if, indeed, it could be called a religion at all. At a much later day, Wilson wrote: "The prevailing notion seems to be that God, after having made the world and filled it with inhabitants, retired to some remote corner of the universe, and has allowed the affairs of the world to come under the control of.evil spirits; and hence the only religious worship that is ever performed is directed to these spirits, the object of which is to court their favor, or to ward off the evil effects of their displeasure."

In short, their religion began and ended in a belief in spirits. Animistic, oppressed, infinitely crude, the poor savages were subjects by night and day, to a host of good and evil spirits. If drowned in the river, one's family believed that it was merely a case in which the water spirit was victorious; if eaten by a wild beast, it was still the working of an evil spirit; if struck by lightning, the same; if in a dream, the realization of a seeming duality of one's personality was positively convincing that the spirit had gone hunting, fishing or what not. This second personality, 
this second in-dwelling spirit, this second part of one's individuality was called the "kra." Man's disembodied, ghost-like spirit, wandering after death was called "srahman."

The despotism of such a system was almost inconceivably severe. It was inevitable that such beliefs would give opportunity for some charlatan of a bolder nature than that of his fellows to claim to be able to influence, tame, or direct the spirits Hence, witch doctors, "voodoo" doctors, "conjur" doctors, priests or "medicine men" arose. "White art" was the name given the protective achievement which consisted in placating injured spirits and protecting oneself against evil spirits by wearing "gree-gree" bags, amulets and charms, that were sold by the witch doctors and were eagerly bought and worn by the ignorant natives. The charlatans grew richer in purse; the people, bankrupt in purse and religion. But not only did the African on his native heath have to contend with evil spirits in their normal nefarious workings; he also had to contend with evil spirits which, through the influence of witch doctors, might be directed at one. "Black art" or the setting of evil spirits on a man became a tremendous business. Witchcraft in its most revolting forms flourished under these conditions. Death was no longer ascribed to natural causes, but was attributed solely to spirits. Under such conditions a death was an especially serious event in a community, since none was spared from the inexorable workings of a witchcraft law which required the sacrifice of the life of the man said by the witch doctor to be responsible for that death. Thousands of innocents must have given up their lives because of this systematized, criminal, religious belief.

The saddest feature of their religion, however, was the fact that it made no pretence of dealing with the relationship of man to man. It was a vertical religion, i. e. a religion between man and the spirits above, in contradistinction to horizontal religions, which endeavor to make man's conduct toward his fellow man the criterion of his love for God. "Their religion is not in any way allied with moral ideas," says Ellis, "and the only sins properly speaking, are, first, insults offered to the gods; secondly, neglect of the gods." J. A. Tillinghast in a luminous summary concerning conditions among Africans in Africa, said: "Even within the village they thought little of destroying the sick or 
useless, and could not comprehend sentiments of compassion. A large portion of their population was enslaved. Polygamy prevailed, women were bought and sold, and chastity was valued only as a salable commodity. Parental and filial affection, with the exception of that between mother and son, was weak and transient. Social morality was not supported by religion, the gods being supposed to have no interest in the conduct of men toward men. Their religion was a dark and cruel fetichism." With such religious endowment well might our forefathers have referred to those natives imported into Virginia as benighted, superstitious Africans.

One or more very brilliant Negro writers of the present day seem to lay the whole burden of the Negro's present sins on the back of the white man because of the Negro's experiences during slavery. This seems to us to be very unfair. We grant that slavery had its vices, but it also had its virtues, and prominent among its virtues in Virginia, was the care exercised in training the Negro religiously. We believe that the Negro is and has been in a process of religious evolution, which opinion is in entire contradistinction to those authors who would make us believe that Africa was a Garden of Eden, and the Fall and the consequent myriads of sins came after the white slave dealer, the Serpent, had beguiled the Negro into Christian America there to partake of the fruit of a tree of systematized labor and Christian love. With far greater appreciation for kindnesses received; in a far sweeter spirit of charity; and with far greater praise for her race, Phyllis Wheatley, a slave freed by her master, wrote

\footnotetext{
“'Twas mercy brought me from my pagan land, Taught my benighted soul to understand That there's a God-that there's a Savior too: Once I redemption neither sought nor knew. Some view our sable race with scornful eye 'Their color is a diabolic dye' Remember Christians, Negroes black as Cain, May be refined and join the angelic train."
} 
This introduction was based on the following accounts of life in Africa:

Atlanta University Publication. No. 8, "The Negro Church," edited by W. E. Burghardt Du Bois.

Bosman, J., "Description of the Coast of Guinea."

Dord, J., "The Negro Races-A Sociological Study."

Du Chaillu, Paul, "Explorations and Adventures in Equatorial Africa."

Ellis, A. B., "The Tshi-Speaking Peoples of the Gold Coast of West Africa."

Ellis, A. B., "The Ewe-Speaking Peoples of the Slave Coast of West Africa."

Ellis. A. B., "The Yoruba-Speaking Peoples of the Slave Coast of West Africa."

Ellis, A. B., "A History of the Gold Coast of West Africa." Kinglsey, Mary, "Travels in West Africa."

Kingsley, Mary, "West African Studies."

Stanley, H. M., "Through the Dark Continent."

Tillinghast, J. A., "The Negro in Africa and America:"

Wheatley. Phyllis, "Her Poems."

Williams, Geo. W., "History of the Negro Race in America."

$\boldsymbol{l}$ 


\section{THE SEVENTEENTH CENTURY.}

It is the consensus of opinion among later historians that Negroes were first brought to America during the summer of 1619. The introduction of another race caused new complications-new adjustments-and these are important considerations in the life of a newly planted colony. We can postulate at least three things concerning these newest arrivals. In the first place, they had to be set to work, and this was not the easiest problem in the world, in consideration of the fact that the Negroes usually imported were densely ignorant, frequently inordinately lazy, and all had to learn the English language or be instructed by signs until they knew how to understand verbal orders; in the next place, the Negro was taken into the colony by the whites solely for the purpose of profiting by his labor, and not for social purposes; in the last place, the early inhabitants of this colony had a busy time fighting Indians. clearing land. tilling soil, and trying to escape the ravages of disease, thus leaving a limited time for the conversion of the savages from Africa.

The sculptor who would chisel an inscription demands and prepares a suitable surface for his work. If he is to chisel a new inscription on an old monument, he must first remove the old inscription. It is hard enough to build on a good foundation, but when debris is to be removed and a new foundation placed, the labor is doubly hard. If the Negro had known nothing, he could have been taught much easier than was possible under the existing circumstances. It is certain that the Negro came to America with his mind reeking with gross superstitions, depravity, and ignorance so profound, that he clung to these while facing the inevitable, with an enthusiasm worthy of a zealot. Their barbarous natures, moral degradation and fantastic beliefs were already deeply chiseled into the tables of their hearts. For the reception of a holy inscription such a worthless foundation had to be removed before a Christian foundation could be laid. The transition from a belief in multitudinous spirits to a belief in a pure monotheism was a mental ascent which even the most intellectual would have found difficult. To 
have taken the untrained, unrestrained, sensual savage from Africa, and to have labored with him until he was made into a self-controlled, virtuous, prayer-loving Christian, was a task which might well have called for the supremest effort of the Christian men and women of Colonial Virginia. We need not be surprised that the hearts of the early Colonists (even those who were especially interested in Christianizing the Negro) grew faint at the prospect before them.

It was not alone because of the stupendous labor involved that the colonists hesitated to Christianize the Negroes during the seventeenth century. It was a matter far more serious. Let us whisper it gently even at this remote day-it was because the opinion was current that the negro was a beast. This belief was in evidence certainly up to the latter part of the seventeenth century and in all likelihood extended into the eighteenth. ${ }^{1}$ Not only in America, but in England this notion had weight. It seems bitterly cruel to us now to think of such a state of public opinion, whether it was held by only a few or by a majority of the colonists. The actions of some of the worst slaves imported probably gave some grounds to substantiate the vagaries of the upholders of such a theory. That the Negro was regarded by some colonists as only a little above the monkey is almost certainly true. A reflection of this is seen in the eagerness and seriousness with which Morgan Godwyn argues that the Negro is man: "Methinks that the consideration of the shape and figure of our Negroes Bodies, their Limbs and Members, their Voice and Countenance in all things according with other Men's; together with their Risibility and Discourse (man's peculiar Faculties) should be sufficient conviction." 2

1. A vile book entitled "The Negro is a Beast" was published as late as 1896.

Montesquieu also said: "These creatures are so black and their noses so flat, it is impossible to compassionate them. It is difficult of belief that a wise and good Creater should have placed a soul, much less a worthy soul, in such black, ugly bodies.... It is not possible we should regard these creatures as men, for so we make ourselves no Christians." - quoted on pp. 151, 152 "Travels in the Confederation". (1783-1784). From the German of Johann David Schoepf. Tr. \& ed. by Alfred J. Morrison.

V. 2. Godwyn's Negro's and Indians Advocate, p. 13.

$8-3$ 
It so happened that Godwyn ${ }^{3}$ dealt principally with the Barbadoes, but these islands were our neighbors in those days. In the seventeenth century our histories reveal many points in common. One lady of consecrated character living in those islands expressed to Godwyn her opinion that he might as well have baptized puppies as baptize the Negroes. ${ }^{4}$ Another remarked after the baptism of one of her slaves by Godwyn that the baptism of her black bitch would have been just as efficacious so far as soul-saving was concerned. Mulattoes were baptized frequently. Perhaps the white part was considered worth saving! Negroes were not even permitted to come near religious exercises as they were deemed beyond the pale and could not be expected to share the joys of the Christian life, or undertake its responsibilities. The Islanders argued that as long as the slaves were not baptized God required nothing of them, and the administration of baptismal rites merely tempted God and unnecessarily exposed the baptized to the horrors of eternal damnation to which their certain failure to live upright, Christian lives must inevitably

3. (1) The two phamplets written by Godwyn have such interesting titles, we shall quota them in full. "The Negro's and Indians Advocate. Suing for their Admission into the Church: or a Persuasive to the Instructing and Baptizing of the Negro's and Indians in our Plantations, Showing That as the Compliance therewith can prejudice no Man's just Interest; So the Wilful Neglecting and Opposing of it, is no less than a manifest Apostacy from the Christian Faith. To which is added a brief Account of Religion in Virginia. By Morgan Godwyn Sometime St. of $\mathrm{Ch}$. Ch. Oxon. Judges 19:30 Acts 4:20. "If we must answer for our idle words. how much more for our idle silence?" St. Augustine. London, Printed for the Author, by J. D. and are to be sold by most booksellers. 1680."

(2) "A Supplement to the Negros \& Indians Advocate; or, Some further Considerations and proposals for the effectual and speedy carrying on of the Negro's Christianity in our Plantations (notwithstanding the late pretended Impossibilities) without any prejudice to their Owners. By M. G. a Presbyter of the Church of England. St. Luke 18. 4 "He would not for a while. but", etc. St. Mat. 21. 24 "Afterward he repented, and went. "Who made you Ministers of the Gospel to the White People only, and not to the Taxomeys and Blacks also? Quakers Speech to the Ministers of Barbadocs p. 4 of Negro's Advocate. London Printed by J. D. 1681."

4. See Godwyn Negro's and Indians Advocate, p. $38 \mathrm{f}$. 
consign them. It is also true that many masters opposed the baptism of slaves for economic and precautionary reasons. It was feared that Christian slaves would by eliciting greater sympathy make stronger demands on the food and clothing supplies furnished by their masters, and more important still, their increased knowledge might stir up within their ranks violence sufficiently grave to endanger the lives of their owners."

The same general opposition to the evangelization of the Negro was prevalent in Virginia as it was in the Barbadoes. It was never so intense, however, nor so widespread. The objection that Christians could not be held as slaves for life was persistently urged to the detriment of the baptism of the Negroes. A man was considered by some a dullard, or worse. almost an ass. if he dared to advocate the Christianizing of slaves. $\mathrm{Wm}$. Stevens Perry, writing concerning the Society for the Propagation of the Gospel in the Foreign Plantations said: "With such lack of ministers and ministrations . . . . the late labors which had been undertaken from time to time in behalf of the civilizing and Christianizing of the Negroes, already become numerous and brought within reach of instruction, had wholly ceased." He then quoted Godwyn who could hardly expect very much from the ministry of Virginia in that day since he claimed that they "also are most miserably handled by their Plebeian Juntos, the Vesteries."

If this foregoing evidence were all, we might well agree with a statement in a valuable study, ${ }^{8}$ edited by W. E. Burghardt Du Bois, of Atlanta University, that "the most obvious reason for the spread of witchcraft and persistence of heathen rites among negro slaves was the fact that at first no effort was made by masters to offer them anything better." But the foregoing evi-

\footnotetext{
5. Bowden's "History of the Friends," p. 190. Wm. Edmundson accompanied George Fox to Barbadoes; and he too reprobated slavery. In 1675, he mentions having "negroes' meeting in families" and that, "several meetings were settled on such accounts. He was brought before the Governor on a charge of making the Negroes Christians, and would make them rebel."

6. See Morgan Godwyn-Negro's \& Indians Advocate, p. 172.

7. History of the Am. Episcopal Church-Perry, p. 204.

8. The Negro Church, p. 6.-Atlanta Univ. Publication No. 8-1903.
} 
dence is not all, and we can be quite sure that Godwyn in the enthusiasm of his advocacy, somewhat exaggerated the facts as far as Virginia is concerned. Another prominent Negro, the historian Williams, has said: "In a moral and religious sense, the slaves of the colony of Virginia received little or no attention from the Christian Church. .... The 'white Christians' hated the Negro, and the Church bestowed upon him a most bountiful amount of neglect." Fortunately, for the honor of Virginians, these quotations are only partly true. These brilliant Negroes failed to look deep enough into the records of our colonial history; or if they looked, failed to present the evidence which in its cumulative effect certainly offsets much of this aforestated seeming neglect.

In a short time after the importation of the first Negroes there are conclusive bits of evidence to substantiate the fact that the conscience of at least one "white Christian" was stirred on the subject of the salvation of the blacks. And let us be reminded that this was, at least, fifty-five years before Morgan Godwyn wrote his two pamphlets. In "A List of Names; of the Living in Virginia February the 16. 1623," we find among others following that of Captain William Tucker, the names of Anthony and Issabella, Negroes. ${ }^{10}$ Under the caption, "Musters of the Inhabitants in Virginia $1624 / 5$," we find in the lists of names for Elizabeth City County, "The corporation of Elizabeth Cittie," these interesting entries,

"Captain William Tucker his muster

Captain William Tucker: aged 36: in the Mary and Jane: 1610:

Mrs. Mary Tucker: aged 26; in the George: 1623.

William Crawshaw an Indean Baptised

Antoney Negro: Isabell Negro: and William their child Baptised."11

In a second edition of Hotten the entry referring to Anthony reads "Anthony, negro, Isabell, a Negro, and William her child, baptised." Whether the little Negro child was the only one bap-

†े 9. Hist. of the Negro Race in America, p. 131.

10. Hotten, Emigrants, p. 185.

11. Ibid, p. 244. 
tized, or the whole family, is not of so great importance as the fact that, at least, one Negro was baptized soon after the contact with the colonists in Virginia. This baptismal occasion may well be considered a red-letter day in the annals of the Negro race. It marked the beginning of a stewardship in spiritual things that bound the better elements of the White race to the Negro race until after Reconstruction had run part of its course. It was a very unpretentious beginning of the evangelization of the race, yet it was a successful beginning. The Government Census Reports on Religious Bodies, 1906,12 credits Virginia with 307.374 Negro communicants or members. This host is not a negligible component of the life of our State. The day of small beginnings should not be despised.

The old Registers and Vestry books of the early Colonial Parishes have been badly preserved, if not actually destroyed. In one place, the leaves were torn out and folded to make fire lighters for household use; in another, the leaves were used as tops for preserve jars; in others, the old books were simply misplaced: in still others, burned. Something has happened to most of them. Fires have devastated many old County Court Records. Rats, carelessness and poor systems of filing have added to the confusion. Occasionally, however, a ray of light is shed on our study. A few such cases we shall now present. In 1641 a Negro, John Graween, the servant of William Evans, became the father of a child by a slave belonging to Lieut. Robert Sheppard. The negro father was exceedingly desirous that his child "should be made a Christian and brought up in the fear of God and in the knowledge of religion taught and exercised in the Church of England." By accumulations from the sale of hogs which his master permitted him to keep upon half shares, Graween eventually purchased the freedom of his child. The court declared that the disposing and education of the child should be in the hands of the child"s father and godfather, who undertook to see that it should receive an education in the Christian belief. 13

12 Part I, p. 562.

13. General Court Orders, March 31, 1641, Robinson Transcripts Va. Hist. Mag., vol. 11. page 281.

See Bruce's Economic Hist. of Va., Vol. II, p. 96. 
In 1645, Francis Pott of Northampton County, had two negro children bound to him and by the terms of the indenture he not only bound himself to furnish them sufficient meat, drink, clothing and lodging but also to use his best endeavors to rear them in the fear of God and in the knowledge of Jesus Christ. Mr. Pott bought these children from one of his Negro servants named Emanuel Dregis. The books mentioned in an abstract under the same date, quoted in the Virginia Historical Magazine, were, "The Bible without the Psalms; Dr. William Smith's Sermons; and the Practice of Piety."14 Even if owners of Negroes were not impelled by Christian motives, it would very naturally be to their best interest to give their slaves a knowledge of the rudiments of reading and writing. And how acceptable the Bible was for a text-book in those days! It is true that the Negroes often had to be made to go to church, but this was done quite generally.

In York County Records, Amy Barnhouse wishes all Christian people to know that she gave to Mihill Gowan, a free negro, employed by Mr. Robert Stafford, "a male child borne ye 25th. of August in ye yeare of our Lord God 1655 of ye body of my negro Rosa-being baptized by Mr. Edward Johnson the 2nd. of September 1655 and named William." 15 Mr. Johnson was one of the witnesses to this legal document and signed himself, minister. Mr. W. Ingraham was the other witness. "At a Court held for York County 26 August $1667^{\prime \prime}$ it is seen that Edmond Chrisman's wife took her Negroes to a Quaker meeting. Quakers were under the interdict at that time and the court ordered that Chrisman "restreyne his said Negroes and whole familv from repairing to ye said unlawful Assemblye at his peril." 10

It is gratifying to know that the old records show such a commendable zeal on the part of some in promoting the religious

14. Ms. Court Records of Northampton County, 1645-1651, p. 82. Book No. 3 (orders, deeds \& wills). Abstract of same in Va. Hist. Mag., Vol. IV, p. 407. See J. C. Wise. "The Early History of the Eastern Shore of Virginia," p. 287; also, J. Russell. "The Free Negro in Virginia, 1610-1865," p. 138.

15. York County Records, Vol. 1657-1662, p. ${ }^{* 45}$

16. York County Records, Vol. 1657-1662, p. 324. 
welfare of Negroes. A further search of the records would doubtless reveal many more instances of which the foregoing are samples. One could hardly expect, however, to find in Court Records many details concerning the religious welfare of white people and necessarily much less concerning Negroes. There are a surprising number of references to kindnesses, etc., extended to Negroes, as found in manumissions and papers of commendation, petitions and the like, but those matters are not exactly to our point. It is significant that the church eventually became the agency for carrying out the laws of negro apprenticeship. ${ }^{37}$ The administration of the laws concerning children born of a free English woman and a negro or mulatto was in the church warden's hands. ${ }^{1 s}$

The mother country's missionary interest in Virginia never flagged. Not only were the Indians a matter of consideration in this connection, but the Negroes also received their share. In 1661 the Council for Foreign Plantations ordered that a letter should be sent to the authorities in the Barbadoes and Virginia commanding them to encourage the introduction of ministers who would specialize in the work of converting the newly imported Negroes to Christianity. ${ }^{19}$ The Negro as a distinctive element in our early Virginia days needed the attention of experts. To prepare them for baptism would have been a difficult task indeed, if left in the hands of the Colonial ministry alone. ${ }^{20}$ There is much romance about our early Virginia history, but it is a gruesome fact that the ministers who came here must have sorely taxed the patience of the godly-disposed among the "adventurers." The statutes of that day show a legal wall built around the ministers to prevent them from overleaping bounds and transgressing in such a manner as to involve the profanation of themselves, their parishioners and the church. ${ }^{21}$

17. Hening, vol. 3, p. 57 .

18. Hening, vol. 3 , p. 87 .

19. British State Papers. Colonial, Vol. XIV, No. 59.

See Bruce. Economic History of Virginia, p. 96.

20. Sir Wm. Berkeley wrote in 16r1; "We have 48 parishes..... Ministers well paid and would be better, if they acould pray oftener and preach less."

21. Hening, vol. I, p. 158. 
It seems very clear that the spiritual food doled out to the colonists would scarcely permit them to surfeit, and we may be sure that Negroes under these circumstances should have been thankful that they received anything at all. In reality, the argument advanced that slavery was justifiable because the slaves were Christianized by the slave-holders came precariously near not being true. That efforts were made, however, to accomplish the commendable purpose of Christianizing them, none can deny.

Immorality in sexual matters was positively inhibited in the colony. The Negro was certainly protected here, if anything, better than at a later date. In 1630 , Sept. 17th, we read that: "Hugh Davis is to be soundly whipped, before an assembly of negroes and others for abusing himself to the dishonor of God, and shame of Christians, by defiling his body in lying with a negro, which fault he is to acknowledge next Sabbath day." 22 In 1640. "Robert Sweet to do penance in church according to laws of England, for getting a negro woman with child and the woman whipt."23 The act passed in 1662 in which the English principle Partus senuitur veNtreM was made law in Virginia, concludes with a penalty of double the fines imposed by a former act, "if any Christian shall commit fornication with a negro man or woman."24 Nothing can be more certainly established concerning the seventeenth century than the fact that the "prevention of that abominable mixture and spurious issue which hereafter may encrese in this dominion" was a matter extremely puzzling to the legislators and concerning which they spoke in no uncertain tones. In 1691 it was enacted that "whatsoever English, or other white man or woman being free shall intermarry with a negro, mulatto, or Indian man or woman bond or free, shall within three months after such marriage be banished and removed from this dominion forever." 25 The justices of the counties were to make it "their particular care, that this act be put in effectual execution." It was inevitable that there should be many transgressions, but they are to be ascribed

22. Hening, vol. I, p. 146.

23. Hening, vol. I, p. 552.

24. Hening, vol, II, p. 170.

25. Hening, vol, III, p. 86. 
rather to the frailties of human nature than to any lack of good motives among the colonists. It is because of an utter, almost studied misapprehension of the sincerity of the religious life of the Colonial settlers in Virginia 26 that Negroes have been led to believe that they received no care religiously in the early part of the seventeenth century. It is only fair to both races that the truth be known.

In 1667 one of the impediments to the baptism of Negroes was removed. In the very earliest days of Portuguese activities in the slave trade the justification of the business was that the grand end to be attained would be the salvation of many souls. This argument availed to satisfy the religionists and was gladly accepted by those being benefited financially. Africa was a much darker continent then than now. If the slave trade could save souls, then a double benefit would be derived by the purchaser of slaves: (1) he would be instrumental in converting the heathen, and (2) he would secure the life-long services of capable laborers. Christian people, however, had seen the inconsistency of holding other Christians in slavery. The idea of freedom was inseparably connected with the Christian belief. Hence, men of a heathen land such as Africa were subject to the bonds of slavery, while Englishmen, Frenchmen, and the like. were not liable to suffer that fate, since they were assumed to be Christians, and salvation, as well as freedom, was supposed to be theirs already.

Ever since the Diet of Worms a notion had been half-lurking in the minds of men that baptism and the consequent conversion to Christianity effected the freedom of a slave. What should be done with this question in Virginia? The heathen had been set down here, and others were being bought, Virginians wanted to retain their property at its full economic value, and they wanted, too, to have their negroes saved. Here was the dilemma. According to the reasoning of some, if they had them baptized the Negroes became Christians and thus the piety of the conscientious masters would work injury to their finances by their being forced to release the slaves from life-long servitude.

26. See defense of Virginia by Thomas Nelson Page-The Old Dominion-Plantation Edition, p. 372. 
If they did not have them baptized, the laudable purpose of Christianizing the Negroes would be stopped, the Negroes would grow more degraded (if possible), and the consciences of the best masters would be violently disturbed. With our present perspective, perhaps some of us marvel that anyone should hesitate to save the souls of men because of pecuniary interest. Yet, like economic considerations are powerful enough even in this day to make us moderns do some things that seem as cravenly irreligious. Conscience salve is in existence now as well as then. In those days some conserved their pecuniary interests by trusting to the mercy of God to save the poor, ignorant, black savages; in these days, many aid the Negroes financially in their church-building projects. yet reap rich harvests out of institutions that make it impossible for them to live up to their religious professions. The Virginia gentlemen of long ago endeavored to remedy their defect by passing a law which was ingenious philosophically and legally. This law of 1667 is worthy of being quoted in its entirety: "Whereas some doubts have risen whether children that are slaves by birth, and by the charity and piety of their owners made partakers of the biessed sacrament of baptisme, should by vertue of their baptisme be made ffree; It is enacted and declared by this grand assembly, and the authority thereof, that the conferring of baptisme doth not alter the condition of the person as to his bondage or ffreedome: that divers masters, ffreed from this doubt, may more carefully endeavor the propagation of Christianity by permitting children, though slaves, or those of greater growth if capable to be admitted to that sacrament." $2 \pi$ The foregoing act was undoubtedly a distinct triumph for the forces of righteousness in the effort to encourage some masters to give their slaves full opportunity to become Christians. It removed one obstruction. When this fact is made clear the men of the seventeenth century are seen in a better light.

Whereas we are now surrounded by Negroes and think of the present Virginia Negroes as constituents of a vast host of their race in the United States, conditions were far different in those days of which we have been writing. In 1624-'5 there

27. Hening, vol. II, p. 260. 
were only twenty-two Negroes in Virginia; 28 and even as late as 1649 , thirty years after their first introduction into Virginia, only three hundred were in the Colony.20 In 1671 Gov. Berkely stated that there were two thousand black slaves. ${ }^{30}$ In 1863 - ? Gov. Culpeper reports 3.000 blacks. ${ }^{31}$ Toward the end of the century, however, the numbers of the blacks increased very rapidly. These numbers enter into the reasoning concerning the seventeenth century and would seem to indicate that no one should be surprised if the records of those days show little concerning the religious development of the Negro. The matter of an Indian massacre, the conquering of a wilderness, the arrival of orders, governors and emigrants from Europe, the raising of tobacco and the culture of silk-worms, very naturally, because of a popular demand to know about them. became matters of history rather than the inconspicuous lives of negro slaves on a plantation. Travellers had little opportunity to know their religious state since it would hardly have been in good taste for visitors to delve into the lives of a host's slaves. We do rot do such things now. Whether one's Irish maid is Catholic or Protestant is hardly the subject of inquiry now when visiting. Whether our cook is Baptist or Methodist we generally omit to record in our letters, and certainly do not insert such items in our court records. These facts deserve consideration as a possible explanation of the absence of a great mass of material dealing with the Negro's religious life. The Negro problem was not so clearly recognized in the seventeenth century as now. If we could have been sitting by the fireside when John was talking to Mann or William or Jacquelin about the slaves: and could have realized how anxious coming generations would be to know the facts, what a mass of information we should have copied.

By an act of 1670 the Assembly declared that "all servants not being Christians imported into this colony by shipping shall be slaves for their lives." Those servants that come by land

28. Hotten. Emigrants.

29. P. Force's Historical Tracts. Vol. II, "A New Description of Va.," p. 1.

30. Hening, Vol. II. p. 515.

31. From an account of Lord Culpeper's Compliance with Instructions from the King, McDonald State Papers, Vol. VI. 
were to serve until thirty years of age, if boys or girls, and for twelve years, if men or women. ${ }^{32}$ The act was primarily framed to settle the time of service of Indians captured by other nations and sold to the English, and next to settle who were slaves. Although the word Negro is not mentioned in the act it is evident what it intended to cover when it speaks of "servants not being Christians imported into this colony by shipping."

Christianity thus became a valuable temporal asset to the slave. If the Negro happened to be sent in by shipping from New England, the West Indies, or from England, the fact that he came from a Christian country was sufficient in practice to guarantee him service in this country not longer than the time served by Christian servants. The territoriality of the term Christian was deemed sufficient proof of Christianity, that is, if one lived in a Christian country. one was considered a Christian without proof of the individual profession. Under this law great inconvenience was experienced by masters who were compelled to sell servants; and further, inland immigration into Virginia from another state was practically prohibited to slave holders. Something had to be done.

The preamble to the act of 1682 avers ${ }^{33}$ that many Negroes Moors, mulattoes and others born of heathenish or Mohammedan parentage or in such countries, have and may again be obtained, by "some well-disposed Christian" who "out of piods zeal" may convert them to Christianity and then be forced by circumstances to sell them; but he cannot sell them as slaves in Virginia after conversion, but only as servants because of previous laws.

This state of affairs was considered a grievance by the colony, and an effort was made to remedy it. After the financial strain incident to Bacon's Rebellion, the Assembly repealed the law of 1670, and then enacted a law which made slaves of all servants of non-Christian nationalities, coming into the colony, whether by sea or by land. This law applied to the purchase of servants, whether Christian or non-Christian, with the exception of Turks and Moors in friendship with the English gov-

32. Hening, Vol. II, p. 283.

38. Hening, Vol. II, p. 491. 
ernment. This was a strictly economic measure and by it Christianity after capture could not be used to effect freedom.

Importers of slares naturally disliked the losses sustained by returning Christian Negroes to the places from which they had been imported, or the losses incident to their removal to places where both Christian and heathen Negroes had to serve for life. It is almost needless to say that there was nothing in the act to make one think that there was the least hostility to spreading Christianity among slaves; on the other hand it is clear that the act was strictly an economic one which permitted Christian Negroes to be enslaved.

To prove the interest of the officials of England in the welfare of Negroes in Virginia we may note the inquiries sent by command of the Right Honorable, the Lords of the Committee of Foreign Plantations, to Sir William Berkeley Knight, Captain General and Governor in chief of his Majesty's Colony of Virsinia.

Question No. 20 was: "What number of Whites, Black or mulattoes have been born or christened for these seven years last past or any other space of time?" 24 Among similar interesting documents throwing light on our study is that which embodies the instructions given by King Charles to Lord Thomas Culpeper, who was Governor of Virginia. These instructions cover many points and not the least among the orders was that one which commands that he shall endeavor to have a law passed which shall tend to restrain bad masters or overseers from the exercise of inhuman severity toward their Christian ${ }^{35}$ servants or slaves; also that he is to endeavor to find out with the assistance of the Council and the Assembly, "the best means to facilitate and encourage the Conversion of Negroes to the Christian Religion" and to exercise care that no harm should come to the persons or properties of the colonists. ${ }^{36}$ The same instructions were sent to Francis Lord Howard of Effingham when he was in Virginia. ${ }^{37}$ The instructions are significant enough, but the

34. McDonald State Papers, Vol. V, p. 21.

35. Christian-White indentured.

36. McDonald State Papers, Vol. VI, p. 43, \$ 65.

37. Ibid, Vol. VI, p. $258, \S 63$. 
answers to them are of far more vital consequence for our purposes. Lord Culpeper declared that a law to protect slaves from ill-treatment had been passed, and concerning the second part of the instruction, declared, "Negroes are daily Converted to the Christian Religion, now they are to continue to be slaves forever." 38 The answers are important coming just at this time since it will be remenbered that Morgan Godwyn published "The Negro's and Indian's Advocate" in 1680 and "The Supplement" in 1681. In the light of the legislation in 1667 removing a serious obstacle to the baptism of slaves and with Lord Culpeper's compliance with his instructions before us, we are led to believe that Godwyn was a special pleader. Of course, a man can see what he sets out to see in this world, and it is indisputable that crime or mere wrong-doing is more liable to attract attention than the praiseworthy actions of thousands of men. One intoxicated man on a university campus attracts far more attention than the hundreds of men diligent in their application to their studies. Morgan Godwyn was looking for trouble and he found it. Another man looking for better things would have found them. ${ }^{39}$ However, whatever Godwyn's findings were, we know that he was a Virginia parson and he must have expressed the feelings of many others interested in the Negroes' uplift even though he spoke his and their sentiments as it were, through a megaphone.

Few relics of the seventeenth century are more valuable than the old Parish Register of Christ Church, Middlesex County. From this we shall quote two entries. Under the heading, "Christenings 1682, etc." we read, "Thomas Clincker ye sone of Thomas Clinker by Ginney Bess (a ffree Negro Woman) was baptized 5th of Aug. 1683. Mr. John Cocking Godfather." Under the heading "Christenings 1683 \& 1684," we find, "Phillip Phillips Jane Phillips Sone \& Daughter of Thomas

38. McDonald State Papers. Vol. VI, p. 63, § 65.

39. A Journal of the Life, Travels. Sufferings, etc.. of William Edmundson. Pub. London 1774. p. 329. In a letter from the Barbadoes in 1675 this prominent Friend wrote: "Many of the Blacks are convinced, and several of them confess to Truth, and Things here are peaceable, and in as good Order as can well be expected at present." 
\& Eliza Phillips (both Capt. Creeks negroes) was baptized 2th of Xemb 1683." 40

The power of the Negro priest with his superstitious African rites was tremendous on the plantations. It has been said: "The priest in the African state has already been noted; his realm alone-the province of religion and medicine-remained largely unaffected by the plantation system in many important particulars. The Negro priest, therefore, early became an important figure on the plantation and found his function as the interpreter of the supernatural. the comforter of the sorrowing, and as one who expressed, rudely, but picturesquely, the longing and disappointment and resentment of a stolen people." 41 It would seem that the introduction of these priests-whether priests in Africa or self-appointed in America-was a constant menace to the Christianizing work done among the Negroes who were imported after their arrival, or even among those who preceded them to America. The Burgesses in 1680 enacted that it was illegal for a negro or other slave to carry a club, gun, sword or weapon, and slaves must not leave the plantation without a certificate from the master or overseer and then only on particular and necessary occasions. The frequent meetings of slaves in large numbers under pretense of feasts and burials caused the fear of an uprising. This law, however, would hardly prevent them from attending church with their masters.

When Governor Nicholson, near the end of the seventeenth century, was directed by the English authorities to recommend laws to the General Assembly for the education of the Indians and Negroes in the Christian faith, he complied, but the House of Burgesses, on June 2,1699, retumed this discouraging reply: "Negroes born in the country were generally baptized. but for Negroes imported, the gross barbarity and rudeness of their manners, the variety and strangeness of their.languages, and the weakness and shallowness of their minds rendered it in a man-

40. Original Parish Register, Christ Church, Middlesex County, Va, in Episcopal Theological Seminary Library, Alexandria, Va. Copy was published by the National Society of the Colonial Dames of America in the State of Virginia, 1897.

41. The Negro Church, p. 5. 
ner impossible to attain to any progress in their conversion." 12 This startling reply would seem to indicate that Africa at that time was not such an ideal place as some writers intimate. It further indicates that a godly care had been exercised in favor of the children of the early negroes since those "born in the [this] country were generally baptized." It indicates further that the task of Christianizing the late arrivals from Africa was a well-nigh hopeless one. This pessimistic response certainly boded no good for the future. Time alone was needed. The newly imported negroes were improved by contact with Christian masters or Christian fellow slaves, and a change came with the birth of children. There is no new principle involved in the fear expressed by the Burgesses that the Christianization of those not born in this country was hopeless. The staid, old legislators were merely expressing the time-honored, yet homely principle, "It is hard to teach old dogs new tricks." Missionaries, settlement workers, educators-all people interested in uplift work recognize the principle, and rarely expect results from the old, but rather from the young.

The events of the eighteenth century, however, will prove that the members of the House of Burgesses even though ever so wise counsellors would not take high rank as prophets. Thousands of Negroes were converted before the end of that century and the seemingly impossible was proved to be possible.

Let us briefly summarize. .

In the seventeenth century. 1619, the negro was first introduced into America. In 1625 at least one was baptized. In 1641 , ' 46 , and ' 55 court records show interest in the spiritual welfare of Negroes. In 1661, the Council of Foreign Plantations in England recommended the procuring of ministers especially for the work of preparing the Negroes for baptism. The state regularly frowned down the transgression of moral laws involving the blacks. In 1667, legislation was enacted taking away one of the barriers to the baptism of the slaves. There were very few Negroes in Virginia up to 1650 and then the increase was so rapid that superstition is presumed to have made

42. Calendar of State Papers, Colonial America \& West Indies 1699, § 473 . 
some pessimistic concerning the conversion of newly imported ones. The laws of 1670 and 1682 were economic primarily and only secondarily religious. Instructions to the Governors of Virginia show interest by English officials in the conversion of the negroes in Virginia. Gov. Culpeper reported progress in the work. Morgan Godwyn, once a Rector in Virginia, averred that little or nothing was done for the Negroes and intimated a bad state of affairs in the early church government. Records in one of the few Parish registers extant show the baptism of Negro children. The House of Burgesses declared that Virginia born Negroes were baptized, but expressed little hope for the newly-imported blacks. The religious development of a race of savages must necessarily be slow, but the encouraging feature of it all is that a beginning occurred so soon after their arrival in America. After eighty-one years of the seventeenth century we must recognize that the reach between the religious status of the first Negroes imported in 1619, and the Christian, Virginia-born children and grandchildren of these first barbarians. is remarkable. 


\section{THE EIGHTEENTH CENTLRY.}

It is evident that each century has had its distinctive work to do in the development of the religious life of the Negro. Although so much had been done for the Negroes in the seventeenth century, yet the great importations of Negroes toward the end of that century made the task of Christianizing the newly-arrived ones appear almost hopeless to the gentlemen composing the Virginia House of Burgesses. It was the business of the eighteenth century to manifest the undoubted superiority of the Christian Negro, and to make the movement for their Christianization popular. A false step in this critical period of the Negroes religious development would have been followed by circumstances too sad to contemplate. The optimism of a new-born century was to supplant the pessimism of a dying one.

As early as the year 1700, Mr. Commissary Blair wrote a letter to the Archbishop of Canterbury in which he stated that the ground-work in hand in Virginia was the revisal of the laws, which had been entrusted by the last legislature to a standing committee. Mr. Blair's opinion being desired by the committee concerning the government and the encouragement of the clergy, he not only gave that, but also put in "another shorter one for the encouragement of the Christian Education of our Negro and Indian Children." 1 It is very evident that such an influential person would be a very helpful advocate in such a cause. At this time however, nothing consequential to the Negro grew out of the proposal, but better things were in store later on. In the meanwhile the baptisms continued.2

1. Wm. Stevens Perry-Hist. Collections Relating to the American Colonial Church-Virginia-p. 112.

2. Abingdon Parish Register, Gloucester Co., Va-.Susanna, a mulatto belonging to Joseph Coleman, baptized April 14, 1700."

St. Peter's Register. New Kent County. Va., p. 12. “Moll a negro girl belonging to Madam Field bapt.-. 170-" "Frances and Kate Negroes belonging to Mr. Geo. Poindexter, bapt. Feby. 4th, 1704-5," p. 30. "Negroes belonging to Mrs. Alice Field: Peter, Muscadoras, 
In London on the 16th day of June. 1701, under William III, "The Society for the Propagation of the Gospel in Foreign parts" was incorporated. This society held a meeting within a few days after its incorporation. Its formation was due to a desire to supply the want of religious institutions and privileges in America among the members of the Established Church, and secondarily, to extend the Gospel to the Indians and slaves. ${ }^{3}$ The Society recognized its work to consist of three kinds: "The care and instruction of our people settled in the colonies: the conversion of the Indian savages, and the conversion of the Negroes." The last-mentioned work soon came to be the principal care of the society. Missionaries were sent to America and ministers preached sermons to the members in England telling them of thousands of Negroes in America under Christian governments and living in Christian families, yet faring no better religiously than they did in Africa. Tracts were published and distributed among the slave owners urging them to greater care for the slaves. This society did excellent work in New York and South Carolina, but touched Virginia very lightly. There are two alternatives: either this colony "where, the plantation system reached its best development." * was approximating its duty, or, the English directors feared that the forces of evil here would contaminate their missionaries. We think the first alternative is nearer true.

Tl:e legislation of 1705 is very pertinent to our subject. We have seen that by the act of 1670 all servants imported. being Christians (and in practice from Christian lands) were not permitted to be held in life-long servitude. By the act of 1682 Negroes and Mulattoes were subject to life-long servitude unless they were of Christian parentage or were Christians themselves before their first purchase. In the act of 1705 . only personal Christianity on their native heath, or freedom that could

Mary, Phillis, Anne, Elizabeth, adult, Baptized January ye 2nd. 17-," p. 12.

Christ Church Register, p. 58. Middlesex County. Va.: "James Morris Son of Elizabeth A Mulatto Woman was Baptized by Mr. Andrew Jackson. March ye 15th. Anno Domi 170 5/6."

3. The Gospel among the Slaves. Harrison and Barnes.

4. The Negro Church, p. 4. 
be proved, in England or some other Christian country were considered sufficient grounds to prevent Negroes and Mulattoes from being enslaved for life.5 Their conversion to Christianity after being sold into the West Indies, or any Christian colonies, would not avail to effect their freedom. Christianity was now sufficient only to save the individual for Heaven, but it no longer availed to protect a Negro or Mulatto servant from being enslaved for life, unless very improbable conditions were true, viz: if the Negro or Mulatto had been a Christian in Africa, or had been free before importation into Virginia. The incentive to become a Christian merely to stand a better chance for the life of an indentured servant instead of that of a slave was done away with by this act.

In this same year, 1705, a law was passed which prevented Negroes, Mulattoes or Indians from holding any office, ecclesiastical, civil or military. 6 This must have been a serious blow to any power-loving priests from Africa who had been brought to America. That they struggled to maintain their sovereign sway over their credulous followers would seem to follow axiomatically. Since laws are usually remedial in their effect, is it not fair to infer that Negroes had held offices in the ecclesiastical establishment before this date? In fact it was almost certain that such was the case.

The Negro certainly had no distinguished standing in Virginia before the law. The Burgesses declared in 1705 that the Negro, Mulatto, and Indian slaves in Virginia should be "held, taken and adjudged to be real-estate (and not chattels)." " In 1727 the slaves were to pass as chattels, ${ }^{8}$ and in 1748 the two foregoing acts were repealed and slaves were to be considered as chattels personal. ${ }^{9}$ The amelioration after this was slow but steady.

Practically all of the oldest Bruton Parish Register was destroyed to furnish wrappers for preserve jars. ${ }^{10}$ The binding

5. Hening, Vol. III, pp. 447,448 .

6. Hening, Vol. III, pp. 250-251.

7. Hening, Vol. III, p. 333.

8. Hening, Vol. IV, p. 223.

9. Hening, Vol V, pp. 438, 439.

10. Historical Sketch of Bruton Church-W. A. R. Goodwin, p. 152. 
or stub end of the book is still carefully protected in a steel safe inside a fireproof vault under the historic old church at Williamsburg. In the preparation of this study, that stub was personally examined, and strange to say, one of the few intelligible records that was saved from the preserve jar fate was the record of the baptism of a Negro. We dare not infer what other entries that page contained, but this record is a fact: "Daniel a Negro lapt. November" [1711]. The figures 1711 were not saved from the hands of the Vandals, but the entry above this one was dated 1711 and the entry next below was dated the same. It is almost a certainty that the year 1711 is correct. This moves back the hitherto first known Negro baptism on that register thirty-six years. In the death list of the same period we find the deaths of Negroes recorded in the same list with the whites. Although we have no direct statement to the effect that these Negroes were Christians, still as Rev. E. Ruffin Jones has said. "it is probable that these Negroes were baptized members of the church." There were certainly numbers of Negroes baptized. at that time." Baptism in the Colonial days constituted real membership in the Established Church since there were no Bishops in America to confirm any, whether white or black. The Established Church made an effort (feeble it would seem) yet an effort, to care for the souls of the Negroes. An important factor is here often overlooked but should be considered, the Church had to deal with the Negroes at a time when there were only a limited number of American born ones among them. and even these were often inattentive, careless and discouraging and were frequently violently perturbed by the superstitions of the ones freshly imported. Both whites and blacks suffered

11. Parish Register. St. Peter's. New Kent County, Va.: “Jno. a negro belonging to Mr. Wm. Clopton bapt. June ye 25th. 1710," p. 5. "Richard a negro child belonging to Capt. Richd Littlepage Baptized August ye 14th, 1711." p. 21.

Abingdon Parish. Gloucester County, Va.: "Elizabeth a negro belonging to John Lewis. Esq. born June 1st baptd. 23d. 1716." "Elizabeth a negro baptized July ye 8th. 1716. belonging to Mann Page Esq."

These entries become voluminous as the years roll on. The ones here quoted are only a few chosen from the many. 
too, because of the poor quality of the clergy in the Colony near the beginning of this century. About 1720 the clergymen in Virginia were considered bad,12 and some parishes had no minister at all. ${ }^{13}$ Virginia had 72,000 Whites and 23,000 Negroes in 1715.14. In other words the old church in spite of tremendous odds did succeed in creating the taste for the Christian religion, and endeavored to feed the babes on the sincere milk of the Word; the Presbyterians gave the Negroes a course in solid food: but the great, joyful banquet was spread before the hungering and thirsting blacks by the Baptists and Methodists later on in the century. It is absurd to undervalue any of the factors active in the religious uplift. It seems, however, a great injustice to historical facts. to assert, in the face of the efforts of Mr. Commissary Blair, Rector of Bruton Parish, and other Episcopal rectors, that "it was as late as 1756 before any white minister had the piety and courage to demand. instruction for the slaves." 15 The Established Church did much more work for Negroes than it has ever been given credit for doing.

In the year 1724 the Bishop of London directed inquiries to the clergy in Virginia concerning the state of the Church and its work. One question was, "Are there any Infidels,"18 bond or free, within your Parish; and what means are used for their conversion?" 17 The answers returned by some of the rectors are very interesting and instructive. From York Hampton Parish, York County, Fran. Fontaine replies, "I know of no Infidels in my parish except Slaves. I exhort their Masters to send them to me. to be instructed. And in order to their conversion I have set apart every Saturday in the Afternoon and catechise them at my "Glebe House." 18 George Robinson wrote from Bristol Parish in the upper part of James River: "None

12 Perry-p. 257.

13. Perry-p. 25-Governor Drysdale's letter to Bishop of London.

14. Chalmers' Amer. Colonies II. 7. Quoted in Campbell's Hist. of Va. p. 383, note.

15. Williams Hist. of the Negro Race in America. p. 131.

16. Bishop Meade, Old Churches, Ministers, Families, p. note "Infidel before 1730 in Virginia merely meant irreligious."

17. Colonial Church-Perry.

18. Ibid. p. 281. 
that I know of except Negro slaves and a few Indian Servants. I have several times exhorted their Masters to send such of them as could speak English to Church to be catechised but they would not. Some masters instruct their Slaves at home, and so bring them to Baptism, but not many such." 19 Emmanuel Jones of Petworths Parish, Gloucester Co., answered: "I have no Indians in my parish, but those several Infidels, Negro slaves brought from Africa, and such as are born in the Country, their masters very often bring them to read and send them to the church or minister to be further instructed that they may be baptized. and many are so." 20 In Elizabeth City Parish, Elizabeth City County,"1 "The owners are generally careful to instruct those that are capable of instruction and to bring them to baptism." Rev. James Falconer found it impossible to instruct the newly-imported ones since they never learned to speak or understand English perfectly. James City parish 22 reports much the same. Mr. Thomas Dell, another rector complains of the distance the Negroes have to come and cites the fact that masters would not always let their slaves have horses. ${ }^{23}$ At Accomac on the Eastern Shore many Negroes attended church and about 200 had been baptized. ${ }^{24}$ Commissary James Blair, of Bruton Parish, IVilliamsburg,"-5 encouraged catechising and baptizing the English speaking ones, and their owners became sureties for them at baptism. In Washington Parish 20 after the slaves had been duly instructed they were adimitted to laptism and the Lord's Supper. An abundance of such evidence could be adduced, but the foregoing proves that some efforts had been exerted to provide for the Christian education of the benighted blacks. It is further true that some masters were exccedingly careless concerning the spiritual welfare of their slaves in spite of the good examples set by others. The

19. Perry Colonial Churches, p. 267.

20. Ibid Colonial Churches, p. 287.

21. Ibid Colonial Churches. p. 293.

22. Ibid Colonial Churches, p. 265.

23. Perry Colonial Churches, p. 255-256.

24. Ibid Colonial Churches. p. 301.

25. Ibid Colonial Churches, p. 299.

26. Perry Colonial Church. p. 291. 
same amount of energy, if expended now, would perhaps start a Welsh revival, but the conditions were exceedingly unfavorable in the country during Colonial Virginis days for sirearing the Gospel among them.

The act of 1680 concerning unlawful meetings of slaves, we may be sure, was not directed against the religious improvement of slaves nor intended to prevent them attending church in company with their masters. In the early days except for the position of the seats in church and the order of communing, very little was heard of the color line in things religious. After the act of May, 1723, there could not possibly be any doubt on the subject of desiring the church attendance of Negroes, since that kind of assembly was expressly excepted from the enactment against the meetings of great numbers of Negroes and other slaves. The law not only excepted their Lord's day attendance but carried no prohibition against meeting at other times stipulated by lawful authority, for public worship. $=\pi$

Rev. Hugh Jones, A. M., sometime Chaplain to the Honorable Assembly and minister at Jamestown in Virginia, published a book in London in 1724 which included some account of the English and Negro inhabitants of the colony.2s In that work he stated that "Several of the People" disapprove of baptizing Indians and Negroes but he could easily refute their arguments, if such Indians or Negroes are good, sensible, understand English, have been taught (or are willing to be taught), the principles of Christianity, and further, if such Indians or Negroes are kept to the observance of Christianity afterwards. Christianity, he contended, improved them as servants. He had no faith in baptizing "wild Indians and new Negroes" who "obstinately persist in their own barbarous ways" since to do so aroused within him a question as to whether it was not "a Prostitution of a Thing so sacred."

In the same year that Hugh Jones issued his book, a very notable proposition was made by Commissary Blair for encouraging the Christian Education of Indians, Negroes and Mulatto

27. Hening. Vol. IV, pp. 128, 129.

28. The Present State of Virginia Hugh Jones pp. 70, 71. 
Children. ${ }^{29}$ In this, the imported slaves are recognized as being "much more indocile," because of their failure to understand English, than the young slaves bom in the Colony. If the young slave be baptized and be able to give a good account of the Creed, Lord's Prayer and Ten Commandments in Open Church, before he is fourteen years of age, his master shall receive a certificate and this slave will be exempted from taxation while between the ages of fourteen and eighteen. Of course, slaves who were not baptized and were unable to understand these matters of faith were to be subject to taxation at fourteen years of age. The Commissary concludes his proposition: "It is humbly supposed the advantage of 4 years' difference in levies will have great effects to this purpose." Surely this matter of exempting Christian legroes from taxes for a period, was nothing more than a proposition to pay the slave owners the equivalent of four years taxes to have their slaves made Christians. It was fundamentally a proposition to put the State into the business of paying for Christians at so much per head. It was a crude way to make Christians. yet it was not a very surprising proposal according to the economists of that day, who. so frequently saw things only in terms of pounds, shillings and pence. ${ }^{30}$ It sounded. however, as if the Commissary were at his wit's end. So far as is known nothing came of the great proposition. Baptisms took place with greater frequency, but the state did not pay for the slave-owner's godliness or the righteousness of the slaves. In the light of this proposition it should be very evident that the Negro's religious training was not ideal; yet this is very different from asserting that nothing was done for the Negro at all.

In the mass of contradictory evidence of this period we can be certain that something was done and something was left undone. How like a voice in the present speaks Mr. Lang in

29. Perry Colonial Church Papers, p. 344.

30. Commissary Blair urged upon Seymour, the British AttorneyGeneral, the necessity of a grant of two thousand pounds to establish a college in Virginia to train young men for the ministry; and even ventured to remind him that the people of Virginia had souls. "Souls," cried Seymour, "damn your souls. Make tobacco." Quoted in foot-note of R. R. Howison's History of Va, pp. 157, 158. 
1726. In a letter to the Bishop of London, he refers to the fondness of some persons for bringing Negro servants to Baptism as soon as they know the Creed, Lord's Prayer and Commandments; and then goes on to state that the Negroes after that live sometimes without marriage ties or common decency, just as if they were pagans instead of Christians.31 The God- fathers and Godmothers, too, often fail to perform their proper duties because of ignorance. His message is not new; it is not old; it is universal. It is almost unquestionable that the same breach between profession and performance has ever existed and ever will, with varying degrees of success in approaching the ideal. His complaint sounds like one heard on the rostrum crying against wickedness, yet offering no way out. Undoubtedly many an Elijah in those days believed that he was the only one left to bow the knee, and would have been surprised, had he looked around him and seen the many righteous.

The Princess Anne County Records for 1727 show that David James, a Negro boy, was ordered to be bound to Mr. James Isadel, "who is to teach him to read ye bible distinctly also ye trade of a gunsmith that he carry him to ye Clark's office \& take indenture to that purpose." 32 This custom of including Bible training in the indenture for apprenticeship was not uncommon and was a very praiseworthy one, since it must have lead to the dissemination of Christian education to some extent. In the midst of the primaeval darkness of the African mind even a little spiritual light meant progress.

Among the big planters of an early day many had a sincere interest in the religious welfare of their servants. For instance Mr. Robert Carter, known as "King" Carter of "Corotoman," rebuilt the historic Christ's Church of Lancaster County about 1732.33 The agreement on the vestry book showed that he reserved one-fourth of the building for his tenants and servants. Such consideration for his dependents as Mr. Carter showed is illustrative of the endeavors of the better class of masters in caring for their slaves religiously.

31. Perry-Colonial Church Papers, pp. 346-348.

32. Princess Anne Court Records cited in V2. Mag: of History Vol. II, p. 429.

33. Meade Old Churches, Vol. II, p. 116. 
The fact that there were tivo or more kinds of masters, the good, bad and indifferent, must not be forgotten in studying the relationship of the two races before 1865. This fact, too, must be remembered: the Negro was not merely to have religion poured into him, after the fashion which we adopt in giving medicine to children, but there was a tremendous responsibility on him to show a life that proved the presence of Christianity . in his heart. Failure to do this, would discourage many a slaveholder, doubtful as to the ability of the slave to assimilate the strength-giving parts of religion. That there was some cause to doubt the efficacy of religious influences upon him may be seen by the following legislation. The slaves. as the preamble to an act of the Burgesses of 1732, forbidding slaves to serve as witnesses except in the trial of another slave for a capital offense. recites, had hitherto been privileged to serve as witnesses after they had professed Christianity and had been able to give some account of Christian principles, "but forasmuch as they are people of such base and corrupt natures, that the credit of their testimony cannot be.certainly depended upon" the privilege of serving as witnesses save as specified in the preamble above was denied to them after this time. ${ }^{34}$

Doubtless those who were supposed to be interested in the instruction of Negroes met much to discourage them, much to weaken their faith. In a letter which the Rev. Charles Bridges of St. Paul's Parish, Hanover County, wrote to the Bishop of London, the reverend old gent'eman in Virginia felt that he - needed encouragement in securing funds for instructing $\mathrm{Ne}$ groes. He complained that both he and the Commissary grew old in years and the world began to hang heavy on them. He aroused himself from a nap and called upon the Commissary; but sleep had claimed him by that time and then he was ready to fall asleep again himself. ${ }^{35}$ What could possibly be expected of sleepy old men in such a cause? The most intelligent, missionary secretaries of the present day would have found tremendous obstacles in their way to perform the great task of Christianizing the Negroes; yet these agents were so old and so lacking in enthusiasm in the work that they fell asleep while

34. Hening, Vol. IV, p. 327.

35. Meade Old Churches, Vol. I, p. 419. 
talking on the subject. It cannot be doubted that these men had an interest in the Negroes-Commissary Blair's attitude during his younger years proved his devotion to the cause-but, if it be assumed even for a second. that these-men were the leaders, how feeble must have been the efforts of those that they led. Yet, "many of the colored children were baptized and some of them taught the catechism," in spite of the depression of this period, which may so well be likened to the last days of the wanderings of the Children of Israel in the Wilderness. New leaders and a new spirit were needed, if they were to reach the Promised Land.

Rev. Anthony Gavin was a type of the virile manhood of his day which was destined to bring things to pass for the Negroes' uplift. Other men such as he must have been in the Established Church. This man was given an easy Parish, but the challenge of a hard, frontier Parish attracted his attention. He went to serve it, and on his first journey from end to end of it, baptized 229 whites, 172 blacks, 15 Quakers and 2 Anabaptists. ${ }^{36}$ This was in 1738. In 1742 Elijah Baker was born in Lunenburg County. ${ }^{37}$ The birth of this man is notable since he as a Baptist elder became a power in the country between Richmond and Hampton, and undoubtedly influenced many Negroes to be baptized. In $17+3$ a young Scotchman came into Hanover County with a book of Whitefield's sermons. Several persons read them and soon a small congregation was formed. Samuel Davies was sent down to Virginia by the Presbytery as the pastor for these people and in a few years had a flourishing work started which extended from Hanover into Henrico, Goochland. Caroline and Louisa Counties.3s The Rev. John Todd,

36. Perry-Colonial Church Papers, pp. 360. 361

37. James B. Taylor, Lives of Va. Baptist Ministers, p. 142.

38. Foote's Sketches. Also see.

Letters from the Rev. Samuel Davies and Others; shewing. The State of RELIGION in Virginia. South Carolina, \&c. PARTICULARLY among the NEGROES.

PROV. XXV, 25.

As cold water to a thirsty Soul, so is good News from a far Country. LONDON.

Printed by $\mathrm{J}$. and W. Oliver, in Bartholomew-Close MDCCLXI 
another Presbyterian, also came into Hanover, and their arrival marks an epoch in the religious development of the Negro. These men were willing and anxious to aid the Negro. Perhaps they took courage from the Apostle Paul's words reminding the Corinthians that "not many wise men after the flesh, not many mighty, not many noble, are called." At any rate they felt that the work among the Negroes was an opportunity for real service and they grasped the opportunity.

Bishop McTyeire of the Methodist Church, referring to the work of Rev. Samuel Davies in Hanover County, tells of the Presbyterian minister's arrival there in 1747 with a license from the General Court to preach at four meeting-houses, and then eulogizes his efforts in this striking language: "The work was such as angels might approve." In a few years the young divine had gathered about three hundred communicants, had instructed many Negroes, and had baptized forty.39 In a letter to Dr. Doddridge dated Oct. 2nd. 1750. Rer. Davies states that numbers of Negroes have been proselyted to Christianity and baptized. These seem to be "the genuine seed of Abraham by Faith." A few of them he permitted to partake of the Lord's Supper. "Sundry Catechisms" he expected to add to the Church at some later day."0 11 ith the burning desire of the Negroes to learn of Christ we may be assured that such a character as Rev. Mr. Davies lost no opportunities to ground these blacks in the fundamental truths of Scripture. Rev. Mr. John Todd and Rev. Mr. Wright were also participants in this good work. They report in a series of letters to Messrs. Joseph and Benjamin Forfitt of London the great work that is in progress among the Negroes.1 The Messrs. Forfitt had been sending books to Virginia and the Presbyterian Ministers were literally besieged by whites and blacks to get one or more, when a consignment was ready for distribution. These letters were written between 1758 and 1761. All of them find the neglect of the Negroes, in things religious, appalling. Mr. Davies knows of only one minister within two hundred miles of Hanover zealous in that work;

39. History of Methodism. H. N. McTyeire. p. 233.

40. Perry-Colonial Church Papers, pp. 368-371.

41. "Letters from the Rev. Samuel Davies and others." 
Negroes are generally instructed or left uninstructed according to the character of the clergy. 42 Baptisms continue and most of the Negroes act as "becometh Christians," but some fail. He delights especially in looking up at the Slave gallery and there seeing the Negroes who can read assisting the beginners in finding places in their hymn-books, and "then all breaking out in a torrent of sacred harmony, enough to bear away the whole congregation to heaven." 43

Mr. Todd finds that by 1758 some of the Negroes can read the Bible; others are beginning to read; others can spell; and still others are just learning the alphabet. The conditions among them are vastly improved. The former desecration of the Sabbath by "frolicking, dancing, and other profane courses" has been supplanted by attending Church, learning to read in their homes, praying, and singing God's praises. Their appearance as "affectionate serious Christians" at the communion table was considered especially inspiring. ${ }^{44}$ The Rev. Mr. Wright reported the Negroes anxious for books and thought them as eminent Christians as he served. The religious ones among them, he considered, "the most docile, unenthusiastic converts" he had ever read of or seen. Although his work was not progressing very well among the whites, he found much solace in his work for the blacks. The harvests were so abundant in Virginia that he feared neither the masters nor the slaves would have much time to devote to their books during that particular year.4s In 1761, he could report that between thirty and forty of Colonel Cary's Negroes were under religious impressions. The Negroes' struggles after godliness were truly inspiring. Capt. Bell, a brother-in-law of Colonel Cary, found his slaves benefited by preaching and the learning. His slaves came seventeen miles to reach Mr. Wright's nearest preaching place. The slaves were especially anxious for "Dr. Watt's Psalms and Hymns."

With such facts before them how could the Messrs. Forfitt refuse to send more books? These letters give us a valuable

42. "Letters from the Rev. Samuel Davies and others," pp. 8, 9.

43. Ibid. p. 14.

44. Davies' Letters, pp. 15, 16, 23, 24. Also Foote's Sketches, p. 47.

45. Davies' Letters. pp. 11, 12, 18, 19, 2s, 29. 
insight into the life of that day. They are to be read, however, with these facts before us: First, the Episcopal Clergy were not over-friendly to the Presbyterians, and the lack of friendliness was very probably retaliated; and secondly, these letters were sent to London to encourage the sending of more books, hence the need for them was made very plain. There can be no doubt, howerer, of the great work done by these early Presbyterians. The Negroes not only flocked to their services, but the white masters who attended were compelled to hear the doctrine of enlightenment and conversion for their slaves from the lips of men who could present the facts forcefully. In the midst of the dread of a slave uprising in connection with the -French and Indian Miar, Christianity for the Negroes was urged as the one sure protection from such a horrible probability.

There is a curiosity implanted in many that causes us to enjoy looking into the private thoughts of others as expressed in diaries. The following extracts from the diary of Col. James Gordon, a staunch Presbyterian of Lancaster County, show the interest of a private individual in the Negroes:

"July 15, 1759, Lilla C. and Molly went to Church. I read a sermon to the Negroes. P. 107.

"August 23, 1759, Gave several books among the Negroes. P. 108.

"Aug. 24, 1759. Went to meeting to-day, where we all parted with Mr. Todd. Our Negroes have attended sermons these four days. P. 109.

"Dec. 25, 1759. Some of our Negroes got drunk, that has given me some uneasiness. ${ }^{46}$ P. 112.

"May 26, 1760. Went to meeting to-day-a pretty large company of the common people \& negroes, but very few gentlemen. The gentlemen that even incline to come are afraid of being laughed at. Mr. Minis [one of the Parsons] endeavors to make it a scandalous thing. P. 199.

"Dec. 27, 1760. Went to meeting-heard Mr. Hunt at night. Mr. Caldwell preached-seventy or eighty of the negroes there. Blessed be my God \& Lord Jesus Christ, these are comfortable

46. Wm. and Mary Quarterly, Vol. XI, No. 2. 
times-tho' I have had the tooth-ache \& headache for these three weeks near. P. 205.

"Sunday 16 Aug. 1761. Several strange negroes came to Mr. Criswell to be instructed in which he takes great pains. P. 222.

“Sept. 22. 1761. Making out lottery scheme to raise $£ 300$ for our meeting house." P. 224.

"April 24, 1763. This day the Lord's Supper was administered to about 90 whites \& 23 blacks, more than we ever had before a vast number of people.ts P. 4 .

“Aug. 26, 1763. This evening I had the comfort of receiving a letter from Rev. George Whitefield who landed this day at Urbana. P. 8.

"Sept. 4, 1763. Mr. Whitefield preached to a crowded house. Mr. IV. was obliged to make the negroes go out to make room for the white people. Several, black \& white could not get room. P. 8.

"Sept. 11. 1763. The Lord's Supper was administered to about 115 white \& 85 black communicants. P. 9.

"Imas Sunday 1763. [Several] went with us to meeting. where Mr. Waddell ${ }^{+9}$ administered the sacrament to about 130 black \& white." P. 10.

Another important Joumal is that written by the interesting. straight-laced Presbyterian from the North, Philip Vickers Fithian, who came into the aristocratic life of Councillor Carter's family at Nomini Hall, Westmoreland County, Virginia and served there as tutor during the years 1773-1774. The gay life in Virginia shocked him while at the same time interesting him thoroughly. From a Journal on which Fithian kept. many interesting facts concerning Negroes during colonial times may be gleaned. On Sunday, Jan. 30th. 1774. he dispersed a large

47. Wm. and Mary Quarterly. Vol. XI. No. 3.

48. Wm. and Mary Quarterly, Vol. XII, No. 1.

49. Mr. Waddell was a blind preacher. Settled in Lancaster and Northumberland Counties from 1762 to 1788 . He married one of Col. Gordon's daughters. See Foote's Sketches in Virginia, I. 367387.

50. Philip Vickers Fithian. Journals and Letters. 
crowd of the Negroes, and two of the Carter boys, found dancing in his schoolroom. On Easter Sunday all came out "High, Low, Black, White," but on Easter Monday, a holiday, the Negroes had dispersed to cock fights in the country. Sunday observance, or rather the lack of it, was especially shocking to him and he makes out a case farorable to the better observance in the North. The Negroes worked their plots of ground, had cock fights, cut wood, etc., on Sunday he claimed, and "by five o clock on Saturday every face (especially the Negroes) looks festive and cheerful-all the lower class of People, \& the Servants \& the Slaves, consider it as a Day of Pleasure \& amusement, \& spend it in such Diversion, as they severally chose." Old Dadda Gumby, however, was too much for the young Presbyterian when he chided him for staying allay from church because of hot weather, while he, though only an old Negro, loved the Lord enough to go to church on foot. It would seem therefore that at least one old Negro was alive to carry forward the banner in spite of the supposed iniquities.

The baptisms had now even before the coming of Rev. Mr. Davies, and his colleagues, grown very frequent in Virginia."1 In the old record book of Bruton Parish, there are 1.122 Negro baptisms recorded between 1746 and 1797.52 George Washington, who owned slaves in the Parish, had eleven of his Negroes baptized between 1762 and 1768 inclusive. Mr. Frederick Bryan, Jr., had two Negroes baptized in the latter year, and their entry on the Register constituted an unusually interesting array

51. Albemarle Parish.-Sussex County.

Name-Sex-Owner's Name-given in month day yr. Christened By whom Born

Tom a boy Wm. Pettway same Decr. 15 1740 July 3. 1757

Ede a girl Sylvanus Stokes same Jany 29 174t/2 6th Jany 174 5/6 3 sureties

Lucy a girl William Cook same April 231742 May 5th 1742 3 sureties

Sam a boy Capt. Gee same Novr. 201742 Decr. 12th. 1742 Will a boy Robt. Nicholson same March 19 1743/4 Sept. 23. 1744 As the years roll on whole pages of the register are taken up by the names of Negroes.

52. Historical Sketch of Bruton Church-W. A. R. Goodwin, p. 153. 
of names: "April 10th 1768. Adam \& Eve: Twins, Son and Daughter of Sall, Belonging to Frederick Bryan, Jr." Public opinion had become set on this subject, at least, and the days of doubt were over. Henceforward through this century the Negro is entrusted with more and more liberty while in the pursuit of things religious. The Christian Negro was a fixture in our civilization. Optimism had at last supplanted pessimism.

In $1747-48$, some Moravians or United Brethren from Bethlehem, $\mathrm{Pa}$., undertook long and tedious journeys through Maryland, Virginia and the borders of North Carolina for the purpose of preaching the Gospel to the Negroes. The blacks eagerly received their messages. The proprietors of the slaves, however, did not care for strangers to instruct their Negroes, since they had their own ministers paid to do the work. This opposition on the part of the slave-owners caused the Moravians to desist from their efforts in this direction. ${ }^{53}$

The Quakers were among the most consistent friends of the Negro. We have noticed in the previous chapter, the work of George Fox and William Edmundson in the Barbadoes for the religious training of the Negroes, and we know that the influence of these pioneers was never lost on later generations.

John Woolman when travelling in Virginia in 1757 came to the Western Branch Yearly meeting-between Smithfield and Suffolk-and there declared in a spirited speech that he was interested in the slaves and believed that if the people were divested of selfishness, the same good spirit that gave the Scriptures would engage them to teach the Negroes how to read in order that the slaves might be benefited by reading God's Holy Word.5t The Friends Discipline which is authoritative, also sounds a certain note in favor of Christianizing the Negro. In 1759 it says: "And it is the desire \& advice of this Meeting that none amongst us be Concerned in the Importing Negro Slaves from their own Country or elsewhere, \& that all Friends who have any of them, do treat them with humanity, and in a Christian manner, \& as much as in them Lies, make them acquainted with the Principles of the Christian Religion, \& inculcate Morality

58. Gospel among the Slaves. Harrison and Barnes. P. 48.

54. Life and Travels of John Woolman, pp. 66, 67. 
in them." 55 The revisions of the Discipline in 1806 and 1821 declare that all the Negroes held in Friends' families were to be treated with kindness; and as objects of the common salvation were to be taught the principles of the Christian religion, etc. ${ }^{36}$

There is always the possibility that some may so far forget the provisions for church attendance during the eighteenth century as to labor under the impression that simply because the Negroes had practically no separate churches, therefore they had no chance to develop their religious natures. Such a supposition is incorrect. Almost any reference to the religious life of the Negro during the colonial days makes mention of the free attendance of the blacks in the white churches. Of course in the early days there were poor heating arrangements in the churches-none in some-and this made church going something of a hardship in winter. It even makes us shiver now to think of sitting in such cold. damp places for sermons one and two hours long. From the present tendency of the Negro to prefer heat to cold, we may surmise that not a very great percent of them struggled through the mud of midwinter roads in Virginia, only to reach a church, cold and damp, in which the minister would wam his flock to escape the discomforts of everlasting fire! That the summer attendance was good we have no occasion to doubt. The social feature of the country church meant much even when the preaching was poor.

A very interesting letter written in April, 1765, is preserved, which gives an account of Mr. Whitefield preaching in old Blandford Church, Bristol Parish. ${ }^{57}$ Mr. W. G. Stanard, Secretary and Librarian of the Virginia Historical Society, believes that the writer of this letter was Mr. Robert Bolling of Chellow, who, as a great-great-grandson of the Princess Pocahontas, wielded his literary tomahawk with as great dexterity as his Indian ancestors did theirs of stone. Mr. Whitefield's sermon was evidently disgusting to that writer and he is especially sarcastic in ridiculing Mr. Whitefield's efforts to shed tears. The lamentations of the Africans in the gallery, he claimed, are sup-

55. Ms. Discipline of 1759.

56. Discipline of the Yearly Meeting of Friends Held in Baltimore.

57. Rev. P. Slaughter-A History of Bristol Parish, Va., pp. 23-26. 
posed to have relieved the eminent divine from the drudgery of weeping himself, but the objection was then urged that such a course was unjustifiable as contrary to the Scriptual injunction against causing others to labor on the Sabbath. There can be no question that Negroes were constantly in attendance at the white churches on preaching days, and further, were considered very sympathetic listeners.

The letters of Rev. Thomas Rankin in 1776 show that the audiences that sat under his preaching were intensely emotional and also mixed.:s On Sunday, June 30th. 1776, he relates that hundreds fell out on the floor and on all sides were nothing but streaming eyes. faces bathed with tears and nothing was audible but groans and cries after God and the Redeemer. "The Chapel was full of white and black." On Sunday, July 7 th, when preaching near the home of Rev. Devereux Jarratt, he was frequently compelled to stop his sermon and beg the people to compose themselves. His pleading was in vain: some were on their knees, some on their faces, some were "crying mightily to God," hundreds of Negroes were among them with the tears streaming down their black cheeks. At Ronoaky Chapel where he preached on Sunday. July 21, more than twice as many persons were present as could be accommodated in the house. "In general, the white people were within the Chapel, and the Black People without. The windows being all open. everyone could hear, and hundreds felt the word of God." This last passage was quoted in order that the first of the two sentences would not stand alone. and permit some to continue to distort the facts in the case. The first part of this passage has been frequently quoted to prove that the whites cared little for the religious training of the blacks, by intimating that those outside could not hear the spoken word: but the Rev. Mr. Rankin shows such inferences to be false by the explanation that all could hear. Judging by the experiences of some of our friends who have attended great. packed meetings in midsummer, even in these days of soap and civilization, those who were outside had chosen the better part.

58. Pp. 30. 31. Brief Narrative of the Revival of Religion in Virginia. 
The Methodists early went on record as opposed to slavery. It was John Wesley who uttered that much quoted sentence: "Slavery is the sum of all villainies." The early Methodists came from England and had no understanding of the slavery system as it existed in Virginia, but attacked it nevertheless. The slave-owners were soon incensed at this and forbade the Methodists admittance to their plantations to teach their Negroes. Thus, their religious work was badly handicapped at the outset.59 The Methodists, however, bravely stuck to their task of Christianizing the Negroes. In 1780 a Conference called in Baltimore required the traveling preachers to set free any slaves they might possess. ${ }^{\text {co }}$ Similar legislation followed. The crowning glory of the position of the Methodists. however, is seen in a query and an answer in 1787. Query: "What directions shall we give for the promotion of the spiritual welfare of the colored people?" Answer: "We conjure all our ministers and preachers, by the love of God, and the salvation of souls, and do require them, by all the authority that is invested in us, to leave nothing undone for the spiritual benefit and salvation of them, within their respective circuits or districts; and for this purpose to embrace every opportunity for enquiring into the state of their souls, and to unite in Society those who appear to have a real desire of fleeing from the wrath to come: to meet such in class, and to exercise the whole Methodist discipline among them." 61 This was a positive policy for energetically Christianizing Negroes.

The Quakers after making a good beginning were seriously discredited in their work in Virginia after their failure to participate in the Revolutionary War. They had, like the Methodists, early taken a stand against slavery. Their sphere was somewhat limited, but they did well within that sphere. In 1781 and 1782 and later on, they appointed committees to care for the Education and Religious Instruction of Negroes set free as well

59. Asbury's Journal. Vol. II, p. i1; Vol. III. pp. 253. 257; Bennett. p. 54ĩ.

60. History of Methodism-H. N. McTyeire. p. 375.

61. Ibid.. p. 381. 
as those still held in bondage. ${ }^{62}$ This matter became of so great importance that the Baltimore Yearly Meetings with jurisdiction over Virginia, in 1785, 1790,1791, 1793 and 1808 instructed its delegates to take up and press the business on the several meetings there represented. The Yearly Meeting was interested in "the Spiritual and Temporal Welfare," "the religious and school education of the children of the black people," "further efforts in favor of this people." and felt that this watchful care was necessary for the Friends, because "of our high profession of Justice \& Equity." Joshua Evans, a Quaker, during a long trip in Virginia in 1796 and 1797, held meetings for Negroes and found that they "sat solidly" and "appeared tender." 63 One feature of the Friends" work for Negroes is very interesting. Lipon the authority of Mr. Kirk Erown, Keeper of Friends' Records at Park Avenue Meeting House, Baltimore, we can say that although such zeal is shown in caring for the Negroes, none of that race became members of the Friends ${ }^{\circ}$ Church, so far as the voluminous records in his possession show. ${ }^{64}$

One of the most interesting characters of that day was Rev. - Devereux Jarratt, an able man, one of the Episcopal divines of the eighteenth century who did his duty well. Bishop Meade cites the pious conduct of this man very frequently as an instance of the godly Christian minister. The Methodists owe much to the protection and comfort which he gave to them when they entered this state. Indeed, the man was so humble and so superior in his general conception of the duties of a Christian minister that we are driven to believe that some of the great results attained by the Methodists in their work among the Ne-

62. Ms. Minutes of Hopewell Monthly Meeting-Book B. 1777-1791, p. 190. Ms. minutes of Warrington and Fairfax Quarterly Meeting 1776-1787, p. 123. Ms. minutes Goose Creek Monthly Meeting 17851818, pp. 533, 534. Baltimore Yearly Meeting of Friends 1782. Ms. Minutes of the Fairfax Monthly Meeting, 1776-1802, p. 105 (6th Mo. 1779), p. 110 (8th Mo. 1779). p. 124. (12th. Mo. 1779), p. 243. (10th Mo. 1782). 167.

68. Journal of the Life, Travels, etc., of Joshua Evans, pp. 141,

64. A case has come under our notice recently where a Negro became a Friend in the State of Ohio. 
groes were directly ascribable to the efforts of Rev. Mr. Jarratt. He notes a revival of interest in things religious about 1765 , and finds the revival growing greatly in the latter part of 1775 and the first part of 1776 . Thus, as the Revolutionary War began and when many of the clergy of the Established Church were discredited as Tories. the Presbyterians, Methodists and Baptists were reaping a rich harvest of human souls. The Negro was benefited by this religious upheaval and from all accounts the emotionalism of the whites under religious excitement during that period was the equal of anvthing the Negro has been able to attain emotionally since. ${ }^{\text {as }}$

When Bishop Coke was in Accomac County. Virginia. Nov. 29, 1784, he wrote that he had heard Harry, Bishop Asbury's black, preach sereral times and he believed that this Negro who could not read was one of the best preachers in the world. ${ }^{66}$ In Mecklenburg County, Coke bore testimony against slavery and tried out his method of delivering such testimony without giving much offense. It was simply this, he first exhorted the slaves to be dutiful to their masters and then the whites would receive in good part whatever he had to say. ${ }^{67}$

About this same time. in 1780, the First Baptist Church in Richmond began its distinguished career with only fourteen members. ${ }^{68}$ This church did yeoman service in caring for the spiritual welfare of the Negroes. It is a matter of deep regret that so few individual churches made competition sharp in this type of well-doing.

We have mentioned the hysteria during the Methodist meetings in which the Negroes evidently had their part. From the accounts of prominent Baptist historians ${ }^{68}$ the emotionalism exhibited during the revivals from 1785 to 1791 was also amazing. It was not unusual for a large proportion of the congregation to be prostrate on the floor; some of them lost the use of their

65. A Brief Narrative of the Revival of Religion in Virginia, pp. 12. 13.

66. Coke's Journal, p. 18.

67. Ibid, p. 37 .

68. The First Century of the First Baptist Church. p. 65.

69. Benedict. History of the Baptists. pp. 90. 91: Semple. R. B.. Hist. of the Baptists in Va., p. 10. 
limbs; some were screaming, others shouting hosannas, groaning, or weeping: preachers were scattered through this mass of humanity, some exhorting at the tops of their voices, others praying, still others in heated argumentation with sinners; all excited. Some preachers endeavored to curb this state of affairs while others fanned the flames as though they were sent from on high. It is worthy of note that the work was more extensive and more converts were added where the greatest excitement prevailed. If the Anglo-Saxon with his faculties long accustomed to perfect coördination lost control in such religious awakenings. what must have been the conditions among the demonstrative, emotional Africans. It is certain that vast numbers of the Negroes became Baptists.

The Baptists were at first, strongly opposed to slavery, but they did not arouse the suspicions of the slave-owners like the Methodists and Quakers. Perhaps the expressions of individuals, or by local associations, did not sound quite so pretentious as the constant declarations of General Conferences or Yearly Meetings. As early as 1758 or 1759 , William Murphy and Philip Mulkey established the Bluestone church of the Meherrin Association. Its membership consisted of "several white members, besides a large number of blacks." "a Lasting good was done to the Negroes in this congregation. At Charles City; in the Dover Association, the Negroes were very much in evidence and because of a ruling which forbade them to preach, "they set up a kind of inclependence, and went on not only to preach, but to baptize. It all, however, ended in confusion." $i 1$ At Portsmouth, Va., after the resignation of their pastor, Thomas Armistead. in 1792. Jacob Pishop, "a black man of considerable talents" was employed to preach for them. This arrangement, the historian notes, could not be satisfactory in Virginia.: $2 \mathrm{Da}$ venport's had only a few white members, but because of its situation near Petersburg a number of Negroes of that town had taken membership in this church. These built a meeting-house

70. A History of the Rise and Progress of the Baptists in Virginia. R. B. Semple, p. 222.

71. A History of the Rise and Progress of the Baptists in Virginia. R. B. Semple. p. 112.

72. lbid. p. 35\%. 
and conducted their worship regularly through preachers of color. ${ }^{73}$

The most interesting case of all, however, is the one of the IVilliamsburg Baptist Church.it This church had a membership almost entirely, if not altogether, of Negroes. Moses, a Negro, first preached among them and was frequently taken up and whipped as a reward for his zeal in holding meetings. A man called Gowan, or as he termed himself, Gowan Pamphlet, later preached for them and also baptized. Excommunication was the penalty prescribed by the Association for any person of color who preached, but the blacks showed a rebellious spirit in continuing to hold meetings as formerly. Gowan and some others were "excluded," but were nothing daunted, so they organized a church outside of the Baptist fellowship and continued preaching, baptizing, etc., as formerly. A church book was kept. and in 1791 while the Dover Association was meeting in Mathews County this church with a membership of about five hundred petitioned for admittance into the Association. The Association sent a committee to them to "set things in order" and after the committee's favorable report, the church was received." The foregoing facts constitute one of the most romantic pages of Negro religious history. No one knows exactly when Moses preached in Williamsburg or when Gowan commenced preaching. It certainly would not have been considered important enough to record in Virginia history when so many thrilling governmental events were taking place. It is merely known to us that sometime after a handful of Negroes and Gowan had been excommunicated, they organized a church and gathered about this nucleus $\mathbf{5 0 0}$ converts and received admission into the Dover Association in 1791. Churches were frequently organized among

73. A History of the Rise and Progress of the Baptists in Virginia. R. B. Semple, p. 361.

74. Ibid., pps. 114, 115.

75. A Revision of the 1810 edition of Semple says in a foot-note: "This church had a brief existence. The present church of the same name was organized in 1828 and occupies the ground of the original one. Scervant Jones was for years their pastor, whilst they worshipped in the famous Old Powder Magazine on the public square in Williamsburg." 
Baptists before they were recognized by the Association, but the upbuilding of this particular church must have been the work of several years. In the face of the opposition which a Negro church was liable to arouse, it could not be possible that mushroom growth should characterize the work.76 The Negro Year Book for 1912 gives the date for the founding of this church as $1785 ;$ it John W. Cromwell, Corresponding Secretary of the American Negro Academy, has placed it at 1776.:8 IVe have found no records to verify either date but we believe the church to be the first Negro church in Virginia, if not the first in the whole United States.

In 1794, a Presbyterian, the Rev. Cary Allen was visiting the home of Colonel Skillern, and insisted on having devotions instead of continuing the conversation about the James River. The Colonel called together his family and the Negroes until his house was overflowing and some stood in the yard. After preaching to the whites for a time, he turned to the Negroes and said: "You Negroes, I have a word for you. Do you think that such poor, black, dirty-looking creatures as you can ever get to Heaven? I do not speak this because I despise you, and have no tender feelings for you; by no means. I pity you from my heart. You are poor slaves and have a hard time of it here; you work hard and have few of the comforts of life that you can enjoy; but I can tell you that the blessed Savior shed his blood as much for you as for your masters, or any of the white people. . . . . Break off from all your wicked ways, your lying, stealing, swearing, drunkenness, and vile lewdness; give yourselves to prayer and repentance and fly to Jesus, and give up your heart to him in true earnest, and flee from the wrath to come." is The white people seemed more affected by the address to the Negroes than they were by the one addressed to themselves. The Negroes were almost dissolved in tears. This

76. John Asplund-“"The Annual Register of the Baptist Denomination in North America to November 1, 1790," does not mention the Williamsburg Church, but this is not strange since the church was not recognized by the Dover Association until 1791.

77. Negro Year Book, 1912, p. 79.

78. The Negro Church, p. 30.

79. Fnote's Sketches. pp. 232, 233. 
type of sermon was very frequently preached to the slaves.so It offers little present hope, but deals very freely with the future.

Of the many distinguished travellers who came from the Continent into America in the years following the Revolutionary War, Marquis de Chastellux and Duke de la Rochefoucault Liancourt were two of the most intelligent visitors from France. Rochefoucault, who was here in 1795, '96, '97, declared that Virginians had made greater progress in reforming the barbarity of the old laws concerning slavery than any other state in the Union and further, that "few nations are less addicted to religious practice than the Virginians." $\$ 1$ The humanitarian spirit must have been abroad in the land, and the slaves must have been benefited by this goodness just as Rochefoucault said, but we believe that the distinguished Frenchman was wrong concerning his estimate of religious practice in Virginia, unless he was referring exclusively to the highest class of educated citizens. Bishop Meade as late as 1811 did not expect to see an educated young man who was not an atheist. And the questions, "First. whether there be a God? Secondly, whether the Christian religion had been injurious or beneficial to mankind?" were debated in the literary societies at William and Mary College, a little before the Bishop's ordination. ${ }^{82}$ Parson Weems of Pohick church sold Payne's "Age of Reason," and then the Bible as an antidote. The French skepticism and the ideas of the French Revolution were widely diffused and eagerly adopted by many of the élite, but the masses, the poor people, the common people, the slaves and also a few distinguished people were hanging on the words of some soul-stirred Methodist or Baptist exhorter without being in the least disturbed by the intellectual vagaries of those who believed in no religious practice.

John Davis, an English traveller and writer, taught school in Virginia for a term and records in his book the life-story of a Negro slave named Dick. The old Negro tells of the evil life of Squire Sutherland's eldest son and then says that the second

80. See extract from Bishop Meade's Sermon quoted in A Journey in the Seaboard Slave States. F. W. Olmstead.

81. Travels, etc., Rochefoucault, Vol. III, pp. 84, 90.

82. Old Churches, Meade, p. 29. 
son encouraged all the legroes to go to meeting; encouraged matrimony by settling each couple in a log-house on a good plot of ground and gave every one that could say the alphabet a Testament with cuts. Dick felt the refining influence of this master and very picturesquely the old Negro describes his own quest for a wife: "I had before quenched my thirst at any dirty puddle: but a stream that I was to drink at constant, I thought should be pure,- and I made my court to a wholesome girl, who had never bored her ears, and went constantly to meeting." 83 Davis found that about half of the congregation at Pohick church was white and the other half black.s4 "Among many of the Negroes were to be discovered the most satisfying evidences of sincere piety: an art'ess simplicity, passionate aspiration after Christ; and an earnest endeavor to know and do the will of God." ${ }^{-5}$ If this be considered fulsome praise, hear old Parson Weems, the biographer of George Washington. "Sir," said Weems, "no people in this country prize the Sabbath more seriously than the trampled-upon negroes. They are swift to hear; they seem to hear as for their lives. They are wakeful, serious, reverent, and attentive in God's house; and gladly embrace opportunities of hearing his word. Oh! it is sweet preaching, when people are desirous of hearing! Sweet feeding the flock of Christ when they have so good an appetite." st

Only one who will not see can fail to note the marked improvement in the religious condition of the Negro at the end of this century over what it was at the beginning of the century. The manifold labors of white preachers, and laymen, the awakening interest among Negroes in favor of a better life,

83. Travels, John Davis, pp. 415, 416.

84. See also Bayard, Voyage dans l' interieur des Etats-Unis à Bath. Winchester, dans la Vallee de Shenandoah, etc, etc. pendant l' été de 1791. 2e ed. Paris 1708, p. 168. 'Le lendemain, $j$ ' allai au temple avec tous les vovageurs: c' était un édifice en bois, autour duquel on voyait rangés des chevaux de prix enharnachés avec luxe. Les galeries étaient pleines de négresses et de noirs endimanchés. Dans le bas, se trouvaient leurs maitres et maitresses, dont l' extérieur annonçit que tous étaient pénétres de la sainteté du lieu, et de la solemnité de la cérémonie."

85. Davis Travels, p. 335.

86. Davis Travels, p. 335. 
the encouragements from without and within, at the end of the Eighteenth Century, augur well for the notable amelioration which was destined to take place in the Nineteenth. The experiment of teaching Negroes religiously had proved feasible and as a result of this the roadway was open; it remained for the Negroes to walk therein, if they would reach the goal. 


\section{TO 1865.}

The Nineteenth Century was the most momentous in the history of the Negro race. The threads of the past were gathered up in this century and a cloth of new texture was the result. This new cloth was ready to be used, but the problem was how to use it. It long baffled the brainiest men of that day to know what to make of it and eventually the North and South exasperated with each other grasped opposite ends of the dark fabric and a contest ensued. What happened in the development of the religious life of the Negro in Virginia up to the outbreak of that contest we shall now state.

A political event occurred at the very dawn of the century which threatened to throw a damper over every enthusiasm aroused within the hearts of Virginians in behalf of Negroes. This sad event was the Gabriel Prosser near-insurrection in 1800 . The intended insurrection did not result in the loss of any lives, save those guilty of playing leading parts in this widespread attempt to murder the citizens of Richmond. However, it made white people feel that they were near a sleeping volcano. It is just here that a sad fact must be faced. It is nowhere better illustrated than in the history of the Negro race, and that fact is this: unfortunately, the innocent suffer along with the guilty. After this attempted insurrection had been thwarted by an unusually heavy rainfall and the consequent rising of streams, the laws passed by the Legislature prove the community of interest which color means. The slaves working in the fields of Southside Virginia must have felt the doubts of their masters and mistresses, and were compelled to abide by new restrictive laws just as did the men who had murder in their hearts near Richmond.

As early as 1710 the Burgesses passed an act freeing Will, a Negro, who was the property of Robert Ruffin of Surry, because the Negro discovered a conspiracy among other Negroes, and thus averted a tragedy. ${ }^{1}$ Lord Dunmore succeeded in lur-

1. Hening, Vol. III, p. 536. 
ing away many Negroes at the outbreak of the Revolutionary llar, but small-pox and bad treatment caused these to rue the day that they left home. There are astoundingly few instances in Virginia history to show that animosity existed between the races; and strangest of all, when insurrections were organized, the Negroes who were leading figures bore testimony later, to no bad treatment on the part of their owners. The evidence submitted in the trials of the conspirators of 1800 also shows these very remarkable things: (1) Much of the recruiting for the insurrection was done on Sundays, and mention is made of visits to churches for the purpose; (2) the Bible was quoted freely to urge the dubious negroes to continue faithful in this fight for liberty; (3) the Quakers, Methodists and Frenchmen were to be spared because of their friendly attitude toward liberty.? We see that this attempted insurrection was not exclusively a political uprising against servitude, but was fanned by a religious zeal that transformed the worshipper into the fanatic.

The Legislature of Virginia was interested in the welfare of the Negroes but it was undoubtedly many, many times more interested in preserving the lives of the white people of the State. Much benefit might possibly accrue to Negroes from frequent meetings, but the whites were compelled to set aside the benefits which might accrue to the slaves and legislate in a manner that would tend to save their own heads. Unselfishness is a beautiful virtue, but in the presence of cutthroats a man is very prone to look out for his own neck rather than the interests of the cutthroats. Hence in January, 1804, a bill was passed which declared that the assemblages of slaves at religious meetings or other places at night, were positively prohibited and would be declared unlawful assemblies, subject to penalties prescribed. ${ }^{3}$ But the legislature of Virginia was not heartless. It was at least not deaf to the voice of public opinion, because a bill was passed in January, 1805, removing doubts that had arisen in connection with the bill of 1804 . The bill of 1805 recites in its preamble the facts that good citizens were doubtful concerning

2. Richmond Recorder. Apr. 6. 1803. Testimony of Ben, alias Ben Woolfolk.

3. Hening. Vol. III, p. $10 \mathrm{~S}$. 
the last bill, and feared that it would affect the religious rights of their slaves. By the later bill it was made clear that the previous act could not be so construed as to prevent masters of slaves from allowing Negroes to accompany them or their families to religious meetings, with this one proviso: that the religious meeting be conducted by a regular ordained white minister. Further than this, the whole spirit of the times was in favor of giving the Negroes a chance religiously. The master recognized the superior value of good Christian slaves and it was his privilege to have some free person teach them things religious.

The province of teaching the little Negroes was generally that of the master's wife and the growing young ladies on a plantation. Few Negroes escaped some religious instruction from these good people. Usually on Sunday afternoons, but sometimes in the morning. the slaves would be gathered in to the great house and lessons in the catechism had to be learned.6 The Apostoles' Creed, the Lord's Prayer and the Ten Commandments were also taught. Hymns were sung and prayers rose to the Heavenly Father. Many good masters read sermons to their slaves and we have heard from the lips of a daughter of Mr. A. $N$. Douglas of Loudoun County, that he required his own children to sit by his side as he read Castleman, ${ }^{7}$ or some other writer of sermons, to the slaves. Other masters hired ministers to do this labor of love, while still others preached themselves. 8 John Randolph of Roanoke would often employ ministers to preach to his slaves and after the minister had concluded, he would address them withea few words. According to the testimony of Mr. Henry Carrington of Charlotte County, in the year $1816 \mathrm{Mr}$. Randolph "made a profession of religion, had family prayers, and preached to his servants on Sunday." o Places at

4. Hening, Vol. III, p. 124.

5. Adams, A Southside View of Slavery, p. 56.

6. White and Black Under the Old Regime, Victoria V. Clayton, p. 58.

7. Plain Sermons for Servants. Rev. T. T. Castleman.

8. Virginia: Past and Present. Elizabeth Lee, pp. 26, 27.

9. Powhatan Bouldin, Home Reminiscences of John Randolph of Roanoke, p. 85. 
family prayers were provided and maintained for the Negroes in many families and were usually eagerly claimed by the aspiring, religious blacks." That these customs were firmly established in many families cannot be doubted.

The manumission of slaves had become a very frequent occurrence a little after the Revolutionary War and continued at a rapid rate until nearly a decade after the beginning of the Nineteenth Century. ${ }^{11}$ Events then occurred that checked this tendency. It is remarkable how excellent some of these manumitted Negroes were, and in what high esteem such free Negroes were held in early times by the white people. Such expressions as those hereinafter quoted are seen in not one only, but in many legislative petitions: "An excellent character for sobriety, honesty, and industry," "provided well for their children, and bring them up in a moral way," "supported a spotless character," 12 "his removal from the state would be an injury to the vicinity in which he has resided," 13 and many such testimonials could be quoted to prove that some of the Negroes at the beginning of the nineteenth century had profited by their training in America and were showing noble lives. It is just here that an important fact lies. Evolution does not raise all with an equal swiftness. The individual sport really marks the highest present attainment of any evolutionary process. Without these sports rising above the masses, evolution would be almost inconceivable. Mass evolution is impossible except as individuals rise. It must be much the same with the evolution of races. The sport rises above the masses and a new standard is set; he seems to call them on; he has demonstrated the possibilities so far, and to attain to his height is no longer considered marvelous. The highest attainment of individuals is really what the Anglo-Saxon considers as his legitimate racial evolution. When we speak of "our" writers we choose Shakespeare. Poe. Browning, etc., and they stand for white supremacy. They are not average. The

10. The African Preacher. W. S. White. pp. 31, 32.

Southside View of Slavery. N. Adams, p. 58.

11. Virginia's Attitude Toward Slavery and Secession. Beverly B. Munford, p. 42.

12. Ms. Legislative petitions of Accomac County. A42 and A50.

13. See also, Ms. Petitions Henrico A9470, A9472, A9485, A9517. 
rest of us cannot approach their art. We too frequently deny this privilege to the Negroes of choosing representative men, and consider their representatives as chicken thieves or vagrants. It is unfair to do so. We choose our best and call that evolution; we choose their worst and brand that the Negro's evolution. The exceptional individual is valuable in that he furnishes the incentive to the others. He is not average; he is at the crest of the racial evolution. The average racial evolution will necessarily be infinitely slower than the evolution of picked individuals. As one of the mass of society rises, another falls and the average remains undisturbed. In reality, few processes can be slower than racial uplift. The endeavor must be, however, constantly to raise more individuals above the average that the average may be raised. Professor Straton called attention to these facts at the Birmingham Conference in 1900, when he said: "We must not confuse the rapid development of exceptional individuals, with the evolution of the race. Picked individuals, strengthened often in mental vigor by infusions of white blood, may grow rapidly; but the evolution of the race comes slowlya part of each new element of strength being transmitted by the laws of heredity from father to son, and so on to succeeding generations; and so, slowly and painfully, a race advances. It is not a matter of decades, but of centuries. The Negro race as a whole, however, may go forward higher yet in outward forms, but still deep down beneath these things may lie the tendencies which give color to the fear that they are a decaying people." 14 This statement of Professor Straton certainly checks unbridled enthusiasm and sets us for the task before us. He nowhere, however, denies the value of the individual in a racial evolution. He could not. His emphasis is on the slowness of raising the average. He seems to overlook environment while emphasizing heredity. In reality, if Negroes had to wait to inherit one good quality after another from their parents whilst also inheriting bad traits, ages of time would scarcely suffice for such an evolution. That races progress slowly is trite; that individuals and masses cannot be considered identical is axiomatic; that the individual is nevertheless a part of the mass is

14. Proceedings of Montgomery Conference, p. 149. 
also axiomatic; that a definition of the average differs with the difference in racial viewpoints has been proved by experiment. Even though the status quo of the race at any given time is to be judged from the average Negro, ${ }^{15}$ if he can be agreed upon, the prospects for the best development of the average in the iuture is to be seen in the best development of individuals at any one given time. Upon that highest development hypothesis our whole system of Lniversity education works out in practice, no matter how democratic it may be in theory. Each individual has a distinct part to play in raising the racial average. The individual sports must be cultivated. The Negro is learning these facts.

Near the end of the eighteenth century a mulatto named Christopher McPherson was freed by a Mr: Ross. From an early age Mr. Ross recognized the "fidelity and integrity" of the Negro and had emancipated him in fact, but had postponed the legal emancipation until the 3rd of July, 1792.16 This Negro's case is a very exceptional one; indeed we believe it so exceptional as to demand its insertion here. The heights attained by this man and his social standing, before his brain was affected by too much religion, are absolutely dazzling to our modern eyes not accustomed to such sights. He was a storekeeper for years, and conducted the business with remarkable acumen. On one occasion at Columbia in Fluvanna County, he broke up an incipient slave uprising by charging into the midst of the Negroes and declaring that he would cut off the arm of the first one that struck a blow. John Quarles, the mayor of the town, was a witness to this event and remarked on the fierceness of mien which characterized M'Pherson as he stood with his old Revolutionary sword drawn, ready for execution. Mr. Wm. Waller Hening and many others refer to him as Mr. M'Pherson and give him as high testimonials as men are wont to receive. Mr. Hening wrote from Charlottesville in 1800: "Christopher M'Pherson, the bearer hereof officiated for some

15. E. C. Pell- "The Bright Side of Humanity:" "The average negro has never been portrayed except in silhouette."

16. Other facts concerning this remarkable Negro may be found in Henrico MS. Petitions A. 9182. 
time as a clerk in my office and it is with much pleasure that I am enabled to pay that tribute of approbation which his conduct so justly merits. In his business he was uncommonly dextrous and accurate, - in his demeanor unexceptional. Having engaged a young gentleman to assist me, previous to my acquaintance with Mr. MPherson, it became necessary on his arrival for Mr. M'Pherson to remove. Mr. M'Pherson during his residence with me conducted himself with modesty, diligence and good morals." Other men such as Geo. Wythe, Chancellor of Virginia, Peyton Drew, Wm. Dabney, Robert Pollard, Edm. Randolph, John Wickham, Thos. Marshall, Wm. Wirt, J. Marshall, Mary Randolph and about a hundred others recommended him "as a person of Integrity, Industry, and general good conduct." when he presented a petition to the Legislature in December, 1810, asking for the privilege of riding in a carriage during his old age. It seems that the Richmond Council in June 1810 passed an ordinance which would make a carriage owner forfeit a $\$ 200$ bond if he permitted a Negro or mulatto to use it unless in the capacity of a maid or servant to some lady or gentleman who was riding. ${ }^{17}$ The petition presented by M'Pherson is now preserved in the Archives of the State Library and is marked "reasonable" and "reported," but there is no further record of action on it. It is only natural that the State should hesitate to interfere with municipal laws. We have seen that men in many callings acknowledged the worth of this man apd we know that he rendered an especial service while working in one of the state offices by inventing a good system of indexing. All of his great reputation, however, was soon doomed to be in eclipse after the misfortune of going crazy on the subject of religion. ${ }^{\text {s }}$

17. An ordinance, to Amend the ordinance for regulating Wagons. Drays and Carts, and for other purposes. Passed 1Sth June, 1810. In papers of Henrico MS. Petitions A 9182.

18. The following remarkable document was sent by him to the Legislature: Christopher MacPherson To the Honorable-The Committee for Courts of Justice of the General Assembly of the Old Dominion State of Virginia-I beg leave to introduce myself to you. as being that very express personage, who is set forth in the Revelations of Saint John the Divine, in the 11th. and 16th. verses of 
Thomas Jefferson in a letter to John Adams in 1812 characterized MacPherson thus: "He is a man of color, brought up as a book-keeper by a merchant, his master, and afterward enfranchised. He had understanding enough to post up his ledger from his journal, but not enough to bear up against hypochondriac affections, and the gloomy forebodings they inspire. He became crazy, fogg:, his head always in the clouds, and rhapsodizing what neither himself nor any one else could understand." 19 "Sic transit gloria mundi."

The Quakers at the beginning of this century kept their committees busy by recommending for the Negroes "a more general care in those respects (useful learning) as well as to promote Their adrancement in Religion and Morality." 20 The educa-

the 19th. Chapter, and the first verse of the 20th. Chapter.-To the truth of this assertion, I take my Almighty God to witness; and He will prove the same, if you require it of $\mathrm{Him}$.

"I have the happiness to announce to you and to the World, that the Glorious Millenium was planted on this Earth, on the 15th. day of February in the year of our Lord 1799-Omnipotence, out of his great goodness and peculiar distinction towards you desires me to inform you, that now, it is His wish. that the first acts of His reign on Earth, shall emanate from you; and that you are to enact Laws, founded upon the pure and sacred principles of Truth and JusticeReason \& Religion, Peace \& Harmony and Love and Unity-which no doubt, will be crowned by Faith and Power and Glory-.

"John Adams late President of the United States \& the Senate of the same, failed to pay the attention that was due to His most Gracious Message-as is contained in the enclosed address, - Our Almighty and Most Gracious Father therefore, now, delegates that message to you and after mature deliberation, $\mathrm{He}$ wishes you to make a Solemn and Earnest prayer for His Almighty Will to be forthwith done: and $\mathrm{He}$ will to your perfect Satisfaction, that moment, confirm this Embassy-Inclosed are documents respecting this business, agreeable to the list stated.-I am Gentlemen,

"Your Friend \& Servant "Pherson Son of Christ Alias

"Fierce Son of Christ."

19. Writings of Thomas Jefferson, Vol. XIII, p. 144. Thos. Jefferson Memorial Ass'n edition.

20. MS. Minutes Fairfax Monthly Meetings, Book B. 1776-1802, p. 725. 
tional work of the Quakers was destined to be seriously impeded, however, by legislation later on in this century. At the October term of the Circuit Court of Albemarle County in the year 1818 several gentlemen were summoned to answer the charge of unlawfully assembling slaves and teaching them at the Cove Meeting House. The pastor of the little flock was accused of offering to instruct them and predicting their freedom. The case was continued for several terms and then dismissed.21 It goes almost without question that any law which would tend to restrict the knowledge of the Bible among slaves would be far more honored in its breach than in its observance. And Virginians of that day thought so too. The only reason for passing such laws was a desire to prevent meddlers from coming in and stirring up the Negroes to cut their masters throats under guise of teaching them the religion of the gentle Jesus Christ. The Baptists of Dover Association met in the Nomini meeting-house, IVestmoreland County, in 1802 to arrange for a uniformity among churches in holding church meetings. ${ }^{22}$ It seems that some churches had more slave members than white members. This state of affairs resulted in the slaves having a majority of the male adult vote in some instances. To check the control of the Negroes a plan was sanctioned by which all were admitted to privileges in the church, but only the free male members were entitled to exercise authority. C. C. Jones estimated in 1809 that there were 9,000 Negro Baptist communicants in Virginia. The Baptists had thus early taken a big lead among the Negroes and were never to be overtaken in point of numbers. The Methodists were becoming better adjusted to Southern conditions and their churches were gaining accessions very rapidly. The Episcopalians at the beginning of the Century had lost their grip upon the emotional Negroes who flocked to the Methodists and Baptists. In later years, under the leadership of Bishop Meade an attempt was made to renew the struggle for best service in helping the slaves religiously but the attempt was late. The sceptre had departed. Bishop Meade's good common sense is clearly shown in many instances, but in few more than in a dis-

21. E. Woods-History of Albemarle, pp. 111, 112.

22. Semple, Virginia Baptists. 
cussion which he had with a prominent Episcopal minister who insisted that no one should preach to slaves even in their quarters until the service according to the rubric was used. This discussion took place soon after the ordination of Rev. Mr. Meade, and after waiting for several years the Bishop found his own judgment approved.23 The power of Bishop Meade to influence his communion for devotional living was seen in the solicitude which many had for their slaves, because of his insistence that the servants would make pious members. if given proper attention.24 The opportunities which have come to many a Negro child from the fact of its birth into a Christian family are in many instances to be ascribed to the potent influence exerted by this Bishop and those who wrote sermons for slaves at his bidding, as T. T. Castleman, Churchill Gibson and others. The Presbyterians under the strong leadership of the men of Hanover had long since laid strong foundations for their work among the Negroes. Although their results have never been showy, like those presented by some of the other denominations, they have ever been consistent and patient in doing substantial religious work for the blacks. In 1806, Dr. John Holt Rice obtained a commission directly from the General Assembly "to spend two months in missionary labor among the blacks in Charlotte County, Va., and parts adjacent." $2=$ The next year he was commissioned for three months and each succeeding year for the same period as long as he remained in Charlotte. He preached special sermons Sunday afternoons for the Negroes at all seasons of the year." Dr. Rice was fortunate in that he had a nucleus of Christian Negroes trained under Rev. Samuel Davies while they were living in Hanover, around which he could gather others. Rev. S. J. Price found the Christian Negoes well organized for Christian living, with watchmen to take the lead and report any moral delinquents. These definite trusts the Negroes performed admirably.27 The influence of these

23. Meade, Old Churches, Vol. I, p. 28.

24. Ibid. Vol. I, p. 60.

25. Foote's Sketches-2nd. Series, p. 303.

26. Ibid. p. 301.

27. Foote, p. 303. 
pious old Negroes was tremendous and was a deterrent to many an evil act on the part of sinners of a younger generation. These old men in the midst of their humility were proud to teach the younger Negroes the Catechism and other Biblical truths. Many of these old Negroes, who had learned to read during the eighteenth century taught the little Negroes to read. Their ability to quote Scripture is almost without parallel in this country, and is absolutely the despair of the generations now living in a free country one hundred years removed from the events to which we are referring.

This work for Negroes was not hid-in a corner. In a letter which Mrs. John Thompson Mason wrote to her son Temple in 1816, she says: "Give your poor slaves who work in the field. Saturday to sell what they make, that they may have it in their power to go to worship on Sunday. Attend to your dear children...... Set them an example by having family worship for them and your servants...... etc." 28 Mr. Lawrence Lewis, Geo. Washington's nephew, and his slaves, were members of the same church at Berryville. After the whites had communed on a certain Sunday, one of his servants came forward, and as Mr. Lewis had not communed, he also came forward and knelt by the side of his servant, as Bishop Meade says, "feeling no doubt that one God made them and one Savior redeemed them." 29 It must be distinctly understood. however, that this incident was not the custom. Usually the Negroes communed after the whites, but there were exceptions even to this rule. ${ }^{30}$ As for seating arrangements, when the Negroes attended the white churches in considerable numbers certain seats were set apart for their use. These seats were usually in the galleries, but sometimes on the main floor of the church.

The course of events was undisturbed during the period between 1810 and 1820 by any unusual happenings in the religious history of the Negro. Baptisms and marriages con-

28. Meade, Old Churches, Vol. II, p. 231.

29. Meade, Old Churches, Vol. II, p. 232.

30. A Defence of Virginia. R. L. Dabney, p. 219. 
tinued.31 The War of 1812 was fought, but had little effect upon the lives of the slaves or free Negroes. If that people be happy whose annals are brief, then the Negroes of Virginia must have been enjoying a pleasant period while deyeloping their religious faculties for greater efforts later on. Even though they had been forbidden to meet to learn to read and write, the law expressly provided that this act should not be construed to forbid masters taking their slaves to religious services. ${ }^{32}$ The act was certainly not aimed at the morality of the Negroes, but it was an expedient, made necessary, so the legislators of that day thought, by the danger of Negroes reading incendiary literature and rising in insurrection. Masters were expressly privileged in Virginia to employ persons to instruct them religiously. ${ }^{33}$ It is a source of great gratification to us now to know that our legislators did not let their fears take them quite as far as the people of North Carolina went who ordered patrols to "search every negro house for books or prints of any kind. Bibles and Hymn Books were particularly mentioned." 34

According to the date proposed by the Library of Congress it was in 1812 that an important book was issued. entitled: "Sermons Addressed to Masters and Servants, and Published

31. L. W. Burton. History of Henrico Parish and St. John's Church. Edited and Compiled by J. Stanton Moore.

"List of marriages from 1815 to $1842-$ Rev. Wm. H. Hart."

"At Richmond, Va., March 2, 1816-Jacob, slave to Miss Sherbrooke and Eva. slave to Mr. Thos. Bohannon."

"At Richmond. Va., May 15, 1823-Ned Lightioot and Sophy Buck, both free people of color; license bearing date as above."

"Baptisms"

"Baptized at Richmond, September 13. 1816, Joseph Wills, a black infant, the property of Mr. John Adams."

"Baptised at Richmond. October 17, 1816, Ann Eliza and James Alfred, children of Wm. and Elizabeth Ricardson."

In 1824 the First Baptist Church of Richmond, Va., could report a membership of 820 . Of this number the larger portion were free Negroes and Slaves. See First Century of the First Baptist Church of Richmond, Va., p. 68.

32. Revised Code of Virginia, 1819. pp. 424, 425.

33. Supplement to code of 1833 , p. 246.

34. Weeds "Slavery as It Is," p. 51. 
in the Year 1743 by the Rer. Thomas Bacon, Minister of the Protestant Episcopal Church in Maryland. Now republished with other Tracts and Dialogues on the same subject and recommended to all Masters and Ministers to be used in their families by the Rev. William Meade Winchester John Heiskell Printer." This volume contained six sermons on two texts, Colossians 4:1 and Ephesians 6:8; Dr. Cotton Mather's resolutions concerning slaves, the Ten Commandments with explanatory passages of Scripture; and dialogues. The idea of the book is well expressed in its own words: "I shall therefore confine myself to one, and that indeed a principal branch of this duty, viz: The indispensable obligation of every Master and Mistress lies under of bringing up their slaves in the knowledge and fear of Almighty God."

In 1822, Rev. John Mines, Moravian Brother, pastor of a church at Leesburg, Va., published at Richmond, "The Evangelical Catechism, or a plain and easy system of the principal doctrines and duties of the Christian religion. Adapted to the use of Sabbath schools and families, with a new method of instructing those who can not read." The "new method" of instruction was simply an arrangement for oral instruction. It is certain that the development of the memory under the new system was remarkable. ${ }^{35}$ It must be remembered that even when the laws frowned upon the increase of learning among the Negroes, the Virginia masters taught certain of their slaves in private. That consistent friend of the Negro, Dr. John Holt Rice, brought especially the need of religious instruction for the blacks, to the attention of the citizens of Virginia through a sermon on the duties of the masters to educate and baptize their slaves, published in the Evangelical and Literary Magazine. Vol. VIII. pp. 613,614. This was in 1829.36 It is certain that one of his prominent reasons for aiding so materially in the establishment of the Prince Edward Theological Seminary was his desire to raise up a ministry acquainted with the problems of masters and servants. The seriousness which entered into an attempt to solve this Negro

35. Adams. Southside View of Slavery, p. 57.

36. Harrison and Barnes-pp. 73. 74. 
religious problem in that day is practically beyond the comprehension of any white man of this day. We simply have to go back a century or so to learn how to do work for the religious development of the Negro. The leaders of this work in our day are rarely original; they have only learned a lesson at the feet of their forefathers that they adapt to the new situations.

A memorial of the Richmond and Manchester Colonization Society presented to the Legislature in 1826 reminds us that one of the great aims of the organization was to settle free people of color on the coast of Africa in such a situation as not only to promote their happiness but also to "enable them to spread Christianity and civilization among the people adjacent to their settlement, and gradually through that vast continent," etc. ${ }^{37}$ This twofold purpose assumed that the ones in Africa needed Christianization and civilizing, and further assumed that the free people of color of this country had both.38 Only a blind man could fail to see that the Negro had already undergone a marvelous change religiously, and as he was removed by time, farther and farther away from superstition, he was destined to undergo still greater changes for his betterment. Under stress of eking out an existence in Africa the few sent from this country failed to act as leaven in the lump. What might have been done if the Colonization Society had been successful in securing a large emigration to Africa no one can say. It is enough for our present purposes to know that its promoters in Virginia expressed, and doubtless felt, confidence and a strong interest in the Christian Negro and realized his possibilities, in part, at least.

37. MS. Petition Henrico A9359.

38. Virginians however were not blind to the defects of the free Negroes, as is seen in the Memorial of the Virginia Colonization Society presented some years later-in Feb. 1533-which says in part: "They are (with some happy exceptions) a thriftless and vicious race, degraded in the eyes of the public and even in their own; and ready accordingly for acts of violence and crime. etc." MS. Petition-Henrico A9456. As the years rolled on. Virginians thought less and less of the free Negro. The ante-bellum white men to whom we have talked are unanimous in lauding the slave Negro and disapproving the Negroes who were free. 
A few years before this, in 1823 , a petition was presented to the Legislature by free Negroes of Richmond that shows a lack of church facilities for persons of color. Race consciousness in things religious tending towards church independence was very apparent in this document, yet an excellent spirit pervaded the whole. The unusual value of the petition as a reflection of the religious history of the time is so manifest that we shall present it in full.

"To the Honorable the Speaker and Members of the House of Delegates of the Commonwealth of Virginia. ${ }^{39}$ The petition of a number of persons of colour residing in the City of Richmond respectfully requests; that from the rapid increase of population in this city, the number of free persons of colour and slaves has become very considerable, and altho few of them can boast any knowledge of letters, yet, that they are always anxious of receiving such instruction from public and divine worship as may be given by sensible and prudent Teachers of religion.

"It has been the misfortune of your petitioners to be excluded from the churches, Meeting Houses, and other places of public devotion which are used by white persons, in consequence of no appropriate place being assigned for them, except in a few Houses and they have been compelled to look to private Houses, where they are much crowded and where a portion of their Brethren are unable to hear or to partake of the worship which is going on. Your petitioners consisting of free persons and slaves, have been for some time associated with the Baptist church, a list of their members consisting of about 700 persons has been submitted for his inspection to the Head of the Police of this City, and no objection has been by him made to their moral character.

"Your petitioners for these reasons humbly pray that your honorable body will pass a law authorizing them to cause to be erected within this city, a House of public worship which may be called the Baptist African Church. Your petitioners are aware that they cannot reasonably expect such a privilege to be conferred upon them, except under such restrictions and restraints as are consistent with the laws now existing or which

39. MS. Legislative Petition Henrico A 9335. 
may hereafter be passed for the proper restraint of persons of colour and for the preservation of the peace and good order of society. To such restraints and restrictions they are prepared most cheerfully to submit and altho it would be pleasing to them to have a voice in the choice of their Teachers, yet would they be quite satisfied that any choice made by them should be approved or rejected by the Mayor of this City. They ask not for the privilege of continuing in office any preacher who shall in any manner have rendered himself obnoxious to the Mayor nor can they reasonably expect to hold night meetings or assemblages for Baptizing but with the consent of that officer, and your Petitioners as in duty bound will ever pray."

This petition is signed by 92 free persons of color of the Baptist denomination in Richmond. The Mayor approved of the petitioners and the petition in these words: "I hereby certify that I have examined the list of Signatures of free persons of color hereunto attached and believe them to be respectable.

"I am of the opinion that the prayer of this petition, if granted, may. be productive of benefit to themselves as well as to the white population of Richmond and most sincerely wish them Success.

"John Adams, Mayor of the City of Richmond."

The Master of Police endorsed the proposition thus: "So far as I know, or have heard of the Characters and conduct of the free persons of colour who have signed this petition I believe them to be orderly, well disposed persons: many of them I know to be men of good characters. If what they ask for, in their petition be granted them by the Legislature under the restraints suggested therein. I believe a benefit would result as well to the white, as the coloured population, of the City of Richmond.

$$
\begin{aligned}
& \text { "Joseph F. Price } \\
& \text { "Master of Police." }
\end{aligned}
$$

Several gentlemen other than the above-mentioned ones considered the petition reasonable and endorsed the characters of the petitioners. The Petition was presented on the $3 \mathrm{~d}$ of December, 1823, and a bill was reported on the 10th, but it seems that it did not pass. All in all, at this time we can be sure that a minority of Negroes attended worship in the white Christran 
churches, yet a regrettable neglect of their religious facilities, as well as instruction, was all too frequent. The whites still had much to do.

This growing interest in the care of Negroes received a rude shock which was truly staggering, when a legro preacher named Nat Turner led the notorious Southampton slave insurrection in the summer of $1831 . .^{40}$ About sixty-one lives were snuffed out by Tumer and his followers amid scenes of revolting cruelty in this Sunday night and Monday morning raid. ${ }^{41}$ Nat Turner seems to have been fitted by nature for the miserable role he played in life. His birth took place five days before the execution of Gabriel Prosser and five months after the birth of John Brown. His father was a runaway slave and was never recovered. Nat's early life exhibited marked signs of precocity and he was led to believe while still a child that he was a prophet. In attendance at church he was very regular and eventually became a preacher. His emphasis on the mystic element gave him a strong grip on the slaves, and he was shrewd enough to live apart from most of the Negroes-often going in the woods to remain. He saw signs on leaves, shrubs and in the heavens, and voices spoke to him even at the plow, as he thought, revealing the secrets of the divine will. Such a character was a fit individual to lead his band of deluded, ignorant, black men in such a career of nefarious butchery. A curious appearance of the sun on August 13th 1831,42 was the sign that settled his resolve to make a strike for freedom. Without waming, the career of murder began during a warm summer night when houses were generally unlocked and the masters sleeping. Neither men, women, nor children were spared in the murderous career. A determined stand, however, by a few whites at Parker's field was the first real obstruction that they met. This so demoralized the Negroes, many of whom were drunk from swilling apple brandy, that they scattered, and their reign of terror was brought

40. Slave Insurrections in Virginia (1830-1865), W. S. Drewry, p. 25.

41. Slave Insurrections in Virginia (1830-1865), W. S. Drewry, p. 196.

42. Willias S. Forrest-Historical and Descriptive Sketches of Norfolk and Vicinity, p. 192. 
to an end by the capture and conviction of many of the Negroes involved.43 The whites were naturally goaded to fury by this uprising, yet the remarkable feature of it all was the quickness with which quietude and justice resumed the places so violently usurped by insurrection and anarchy.

Governor Floyd of Virginia and many others had long feit that the religion of the Negroes was little better than superstition. This tragedy confirmed their opinion. The open appearance of the abolition movement had taken place in the early part of 1831, at Boston-only a few months before "Old Nat's War"-under the leadership of William Lloyd Garrison.4 Quakers had been ordered to free their slaves or be excommunicated long before this, and the ideas of freedom were in the air to such an extent that many Virginia masters had manumitted many slaves before this date. Now all was doubt. Many things made it necessary that a feeling of greater security should prevail in Virginia. Who could know when another plot was being prepared? While this feeling of uncertainty was still prevalent, Gov. John . Floyd sent this trenchant message to the Senate and House of Delegates of Virginia on Dec. 6th, 1831: "The most active among ourselves in stirring up the spirit of revolt have been the Negro preachers. They had acquired great ascendancy over the minds of their fellows, and infused all their opinions which had prepared them for the development of the final design; there is also some reason to believe those preachers have perfect understanding in relation to these plans throughout the eastern counties; and have been the channels through which the inflammatory papers and pamphlets, brought here by the agents and emissaries from other States, have been circulated amongst our slaves. The facilities thus afforded for plotting treason and conspiracy to rebel and make insurrection, have been great. Through the indulgence of the magistracy and the laws large collections of slaves have been permitted to take place, at any time through the week for the ostensible purpose of indulging in religious worship but in many instances the real

43. For full details of all this insurrection See Drewry, "Slave Insurrections in Virginia."

44. Burgess, John W. The Middle Period. 1817-1858. p. 246. 
purpose with the preacher was of a different character. The sentiments and sometimes the words of these inflammatory pamphlets, which the meek and charitable of other States have seen cause to distribute as firebrands in the bosom of our society, have been read. . . . . The public good requires the negro preachers to be silenced, who full of ignorance, are incapable of inculcating anything but notions of the wildest superstition, thus preparing fit instruments in the hands of the crafty agitators to destroy the public tranquility." 45

With this executive message before it the General Assembly enacted the bill of March 15th, 1832. By this act no Negro, ordained, licensed or otherwise, was permitted to hold religious or other assemblies at any time. The punishment prescribed for the offender was stripes not exceeding thirty-nine. All $\mathrm{Ne}$ groes were forbidden to attend any such preachings, etc., when such were conducted by a Negro. Without written permission from his owner or overseer, a Negro attending night services even when conducted by a white ordained minister was subject to the same punishment-lashes not exceeding thirty-nine. The arrest in any of the above cases would take place without written precept. All of the regulations above were subject to the following provisos: (1) That nothing in the above should prevent Negroes from being carried or going to places of religious worship with their masters or employers or with persons on whose property they live, when such service is conducted by a white ordained minister in the night time; (2) that the above should not prohibit a white licensed or ordained minister, or a layman licensed by his denomination for the purpose, from preaching or giving religious instructions to the Negroes in the day time; nor deprive the master of the right to employ suitable persons to instruct his slaves; nor prevent the assembly of the slaves of any one owner for religious devotion at any time. There can be no doubt that the act was not framed to lessen the growth of the Negro religiously, but was a removal of the very opportunity of insurrectionary evil and was deemed a step toward a deeper religious life for that race. The honor of the State of Virginia has often suffered in that many a biased writer has

45. House Journal 1831-2, p. 10. 
quoted the first part of this act and has enlarged upon the crime of silencing the Negro preachers and forbidding Negro assemblies, yet has been so unfair as to fail to show that the religious welfare of the Negro was provided for and not neglected.

It is true that in the heat of debate many men made rash statements; many statements were misconstrued; many conclusions were jumped at; many things were looked at from only one viewpoint. During the great slavery debate in the House of Delegates when Virginia came so near approving a policy of gradual emancipation, Mr. Berry, of Jefferson County, speaking on Friday, Jan. 20, 1832, said: "We have as far as possible closed every avenue by which light might enter the slaves' minds. If we could extinguish the capacity to see the light, our work would be completed; they would then be on a level with the beasts of the field and we should be safe! I am not certain that we should not do it, if we could find out the process, and that on the plea of necessity." 46 In contradistinction to this radical utterance the other debaters on both sides usually spoke with great kindness of the masters trying to aid their Negroes, yet recognizing the knotty problem that the Negroes were and would be. Such oratorical flights as Mr. Berry indulged in, while not in strict accord with facts, are rolled as sweet morsels under the tongues, and are quoted with as much confidence as if they had been Holy Writ by those who have seen only one side of the great slavery system of Virginia. It is true that the methods of this early day may have produced a Nat Turner, too religious, or may have produced some, not religious at all, yet a definite effort was made by a large percentage of the good people of Virginia to provide for the religious training of the Negro; and their success can be judged by the product, for verily there is no controverting the fact, "by their fruits ye shall know them."

That the Negro achieved as much as he did religiously, however, is much to his own credit, since there were certainly many obstacles. A petition was presented to the Legislature in 1834, signed by free persons of color, and endorsed by practically all the white ministers of Richmond, as well as by

46. Virginia Slavery Debate, B. W. Leigh. 
several prominent law citizens. In this document the petitioners recite that because of the operation of the Act of March 15th, 1832, many colored human beings are interred like brutes, their relatives and friends being unable to procure white ministers to perform the usual ceremony in the burial of the dead. "Your memorialists therefore pray the passage of a law authorizing free persons of colour, as well as slaves, to perform the ceremony usual on such occasions by white ministers; provided, they obtain a License for that purpose from the Pastor of the church to which they respectively belong for a limited period." 4 is The wanton neglect that made it necessary to present this petition appears unjustifiable. It seems, however, that although this petition was not granted, yet the defects were probably remedied, as no more such petitions were presented. In spite of definite policies which tended to Christianize the Negroes and in spite of many efforts in their behalf, the religious growth of the Negroes appeared to be in eclipse from 1831 until nearly 1845. Of course we do not intimate that all its progress was stopped, but rather that the reaction from "old Nat's IVar" temporarily overshadowed the interest in work for their religious development. When the eclipse period was over, the brightness seemed much greater than ever before. And it really was, too.

The famous First African Church was organized about 1841 is and the religious life of Negroes who attended there soon received the best attention. At other places the Negroes were members of the white churches. Scott and Ailcy, his wife, emancipated Negroes, and the one hundred and thirty or more signers of their petition of 1336 requesting that the two Negroes be allowed to remain in the State, laid great emphasis on the fact of their membership in the Baptist Church and an "attachment to the members of the church to which they belong and their

47. MS. Petition Henrico A9483.

John Marshall, Chief Justice of the U. S., in endorsing this petition said: "I am not apprised of any mischief which would probably result from following the prayer of this petition. Should this be correct I think humanity would dictate that the prayer of the petition be granted with any safeguards which the wisdom of the legislature may suggest."

48. The First Century of the First Baptist Church, p. 254. 
neighbors generally." 49 It is said that up to 1838 no special slave mission was reported in Virginia, yet in the larger cities and even in some small towns there were flourishing colored charges. Norfolk was especially noticeable with its Negro membership of 337-more than the white membership of that city. ${ }^{30}$ In a letter which we have in our possession written by Mr. Thos. B. Rowland, one of Norfolk's oldest and best informed citizens, concerning the city's early history, he states that a Mrs. John Taylor, a wealthy Church of England lady. aided largely, if she did not bear all the expense, of the erection of an African Church in Bute Street, about the year 1832. A white minister was in charge. At Charlotte and Catharine Streets (now Bank Street) some years later the Negro Baptists had a good church which they bought from the Presbyterians. Tradition has it that Old St. Paul's when abandoned about 1816 was partly used by Colored Baptists. Mr. Rowland further states that good families in the olden days always had morning and evening prayers and to these the dependents were required to be present.

There were many masters who proved that slavery could become a paternalistic form of government. Col. Thomas Dabney, who lived at "Elmington," Gloucester County. Va.. left the delightful neighborhood in which he lived at a time when many others were moving farther South, because the expense was great in raising his own family and because he was dissatisfied with the amount of food that he could give to his Negroes.51 He made ample provision that not a single Negro family should be separated by his removal from the State. This tearing asunder of family ties was a very infrequent occurrence in Virginia-usually only at a time of bankruptcy, when the buyer could not be persuaded to take the whole family, or in the division of an estate among heirs who would neither buy nor sell. In the words of an old Negro, Mammy Harriet, we can glimpse a bit of the devotion felt by slaves for a good master: "My husband b'long to Cappen Edward Tabb, an' marster went dyar twice to try to

49. MS. Petition Floyd Co. A 6081.

50. Such, at least, is the surprising statement in Harrison and Barnes, p. 189.

51. Memorials of a Southern Planter. Susan Dabney Smedes, p. 42. 
buy him. But Cappen Tabb say that no money couldn't buy him from him. Den Mrs. Tabb say dat she would buy me, an' two odder people dyar wanted to buy me, too. But I say 'No indeed. Go "long. I shall follow my marster." 52 And she went to Mississippi, too. The frequent presence of ministers at Col. Dabney's hospitable homes, whether at "Elmington" in Virginia, or at "Burleigh" in Mississippi, insured religious attention to his slaves, since Col. Dabney's care of his slaves was, as far as the records show, complete. As an old Negro said: 'Marster 'lowed us to hab meetin', just as much meetin' as we chose. A heap o' people didn't let day people hab meetin'; didn't like for dem to visit to see udder people. Marster warn' dat way." ${ }^{3}$ Such high testimonials are necessarily rare because very few persons preserved the sentiments of their slaves; had they done so an invaluable record would have been preserved by a handsome majority telling of loving ministrations, kind relationships, and religious care.

By 1844 the Methodists of the United States had split into two churches, North and South, because of divergent views on the subject of slavery and in 1846 the Church, South, met in its First General Conference at Petersburg, Va. ${ }^{34}$ The recoil from this breaking asunder required some little time for adjustment, then the church South saw that its zeal must be redoubled in behalf of the Negroes if it would show to the world one of the best benefits bestowed by slavery on a non-Christian people. This church became very liberal in employing Southern whites to work among the Negroes. Such missionaries devoted themselves exclusively to the religious welfare of their charges and did not become involved in controversies over the civil relations of the Negroes. In fact all the Southern churches were aroused. "As the abolition controversy waxed fiercer, the zeal for the negro missions waxed warmer; as abolition societies multiplied at the North, missions among the slaves multiplied at the South; as plans and messages for the final extirpation of slavery were growing into grander proportions at the North, plans and meas-

52. Ibid., p. 48.

58. Memorials of a Southern Planter-Susan Dabney Smedes. p. 58.

54. McTyeire-Hist. of Methodism. pp. 637, 8 . 
ures for the salvation of the slaves were rapidly enlarging at the South." 55 From the Proceedings of the Twenty-Second Annual Meeting of the Baptist General Association of Virginia, assembled in Lynchburg, Va., on May 31st, 1845, we learn that after a resolution had been unanimously adopted to that effect, a committee of seven was appointed "to inquire into, and report the best means of securing more efficient religious instruction for our colored population." ${ }^{6}$ This committee brought in its report and in a preamble stated that it believed that the moral and religious training of Negroes had been neglected, and suggested that part of the blame was to be laid on the activities of the Abolitionists. It realized the difficulties of the situation, congratulated those churches and pastors that had begun the work for Negroes and offered three resolutions: (1) That services should be held for Negroes on the afternoon of every Sunday when practicable; $(2)$ that religious masters invite their servants to family prayers; (3) that the church endeavor to bring Negroes into the temperance reformation. All of these were adopted and the committee was discharged.

The First African Church of Richmond, Va., with its distinguished pastor leading in good works, had already begun its notable career, and it is worthy of remark that this edifice served not only as a church for the Negroes, but was frequently used for large political gatherings by the white citizens.57 The whites and blacks had been attending together the First Baptist Church, but the presence of such a great Negro membership and the lack of sittings for these eager listeners and the impossibility of giving them the attention necessary, seemed to militate against the best interests of the church. ${ }^{\text {ss }}$ The whites were anxious also for a more beautiful building than the old one, and as no ade-

55. Methodist Quarterly Review 1866. Article entitled "Relations of the Colored People to the Methodist Episcopal Church, South."

56. Minutes of the Conventions preserved in Baptist Historical Society at Richmond, Va.

57. See Richmond Whig., Apr. 25th, 1851 et passim.

58. Basis of the following account is a paper entitled "Origin and History of the First African Church," by Robert Ryland, Published in "First Century of the First Baptist Church of Richmond, Va." Pp. 245-272. 
quate plan was presented for the proper disposition of both races, it was considered advisable that the blacks should be allowed to buy the old property for a little more than half of its appraised value, and then have title to it as their own church. Legal doubts were soon settled by finding that a Negro church was not in opposition to State laws provided it had a white minister. The experiment was considered a doubtful one, however. To allay any possible hostile public sentiment the First Church appointed a committee of eight white men to elect the pastor and in tum, attend public worship with him. Dr. J. B. Jeter. pastor of the First Baptist Church, drew up the constitution for the African Church, and this provided for the selection of thirty. deacons and a white pastor by the committee of eighteen subject to the approval of the congregation. Vacancies in the Board of deacons were to be filled by popular vote and the pastor and this Board were to be the ruling powers in the church. No less a personage than the President of Richmond College, Dr.. Robert Ryland, in consideration of many noble reflections, consented to be their pastor. He undertook his duties in October, 1841 , and was their pastor continuously until after the War. His policy was to treat them as he treated the whites "with the greatest possible respect." His discipline was thorough and his habit of instructing them in doctrines gave them something substantial. One of the most valuable acts that he performed for them was the writing of a Catechism of fifty-two lessons which was so arranged that questions could be answered "yes" or "no," with corroborative Scriptures. This partly explains why many of the missionaries who invaded this State after the war expressed such profound surprise that some of the Negroes knew so much of the Bible. Young theologues from the College would sometimes descend on the congregation and preach in response to Dr. Ryland's request. The Negro was an excellent judge of good preaching, if he had been raised on the right kind. One young man from the College after an animated effort heard Deacon Simms, a black brother, importune the Lord for large grace "on our stripling young brother that is trying to learn how to preach." The Negroes were mighty in prayer.j9 Good order

59. Adams, Southside View of Slavery, p. 55. 
was at all times rigorously observed: finances in this church were always in good condition. Between 1841 and 1855 the church grew from 1.000 to 3.000 . so a colony, the Ebenezer Baptist Church, was set up. In spite of an insistence on a man's knowing the principles of Christianity and after making the applicant wait through periods of probation, there were 3,832 additions by baptism to the African Church between October 1st. 1841, and July 1st. 1865. After this later date Dr. Ryland's services were no longer required by the freedmen.

This rather full description of this remarkable church has been presented because it is based upon one of the very few reliable accounts written on the subject of Negro church histories. It was representative of similar work, being undertaken elsewhere with great success, when the estrangement preceding Reconstruction drove the races apart. 'It must be evident from the foregoing that the Negro is capable of attaining a good religious standing, if he has the proper leadership and is put under proper restraints. I In the absence of either of these determinants his religious life suffers.

Among the Presbyterians a noble work had already been in progress for years throughout the state, but an extraordinarily famous name added to those doing such work at one place made this special field of labor doubly famous. A Sunday-School for Negro slaves was established in Lexington, Va., by Dr. W. H. Ruffner and Rev. Tucker Lacy in 1845 with "upwards of 100 pupils and plenty of white teachers." 60 After the removal of these two gentlemen from Lexington, the school languished, until in 1856 Major. T. J. Jackson, later Gen. "Stonewall" Jackson. reorganized it. This great man devoted himself to this work with his customary zeal, consequently success was great. $\mathrm{He}$ gave reports monthly in person to every master showing the progress or defects of the slaves, and he was punctual in attendance himself and always thoroughly prepared to teach the lesson. He had no talent for singing. yet he managed to start a hymn for his pupils. He interested others in the work.61 When his

60. See Sketch of Wm. Henry Ruffner by Anne H. R. Barclay in West Virginia Historical Magazine. Vol. 2. No. 4."

61. Autobiography of W. S. White, p. 143. 
second wife, Mrs. Mary Anna Morrison Jackson, expressed a desire to teach in the white school Jackson urged her to lend a strong hand in uplifting the Negro instead, and later she was happy that she did as he wished.62 Even under the terrific strain incident to commanding duties in the War of Secession, he never forgot his Bible school at home, ${ }^{63}$ and even took pains immediately after the battle of First Manassas to send to Rev. Mr. White a letter containing his contribution for the Negro Sunday-School. His letter is memorable: "My dear pastor, in my tent last night, after a fatiguing day's service, I remembered that I had failed to send you my contribution for our colored Sunday-School. Enclosed you will find my check for that object, which please acknowledge at your earliest convenience, and oblige yours faithfully.

$$
\text { "T. J. JAcksox." } 64
$$

It is also worthy of remark that this school was successful in a town where the Negroes were flocking to the Baptists and Methodists and where a young minister admirably fitted for the work and especially employed by the Presbyterian church to carry on work for Negroes found it impossible to secure visible signs of success. After the war this Sunday-School work was carried on by Col. J. T. L. Preston of Virginia Military Institute, Prof. J. J. White of Washington and Lee University and many of the best people of Lexington."5 Dr. R. F. Campbell, now pastor of the First Presbyterian Church, Asheville, N. C., was superintendent in a Sunday-School for Negroes, organized by a daughter of Dr. Wm. Henry Ruffner, in a settlement near Lexington. That the Negroes were not ungrateful for the consideration shown them by "Stonewall" Jackson is eloquently proclaimed by a beautiful

62 Life of General Thomas J. Jackson, by Mrs. Mary Anna Jackson (his wife), pp. $77,78$.

63. Sunday-School Times, Dec. 3, 1887. Article by Mrs. Margaret Preston.

64. Life of General Thomas J. Jackson by Mrs. Mary Anna Jackson, pp. 181, 182.

65. See Stonewall Jackson-A Military Biography. Reminiscences by J. Wm. Jones, D. D. pp. 500, 501, also William S. White, D. D. and His Times. An Autobiography, Edited by his Son, H. M. White. p. 158. 
memorial window placed in recent years in the Fifth Avenue Presbyterian Church (Colored), Roanoke, Va. The design is based on the immortai dying words of the gallant general and Christian gentleman: "Let us cross over the river and rest in the shade of the trees." The cost of this window was met by Rev. L. L. Downing, the Negro pastor, and his session. There can be no doubt that not one of the least claims of this remarkable Virginian to immortality was the consecrated devotedness which he exhibited in caring for the religious development of the Negro race. Nor was he alone in this work. Besides several already mentioned there were other distinguished Virginians who strove equally hard for the Negro's uplift: Prof. John B. Minor. the renowned law professor at the University of Virginia. Dr. $\mathrm{IIm}$. H. McGuffey of the Chair of Moral Philosophy, Dr. Francis Smith, now emeritus professor of Physics at the University of Virginia. Miss Jennie Nelson, of Hanover County, who taught the little Negroes in the sand when paper was not available, Rev. IV. S. White, formerly of Lexington, Va., and many, many, others, devoted much time and energy to this form of Christian activity. If any work ever gave an adequate return in pleasure to the persons who invested their time in it, this form would rank easily among the first, if we are to believe the unimpeachable testimonies of these and other valiant spirits who labored for the moral and religious uplift of the Negro. The attitude of the South, and especially of South Carolina and Virginia, can be seen from their reports at the great conference which met in Charleston, S. C., May 13-15. 1845, to plan for the religious instruction of Negroes. The President of this body was the venerable Daniel Elliott Huger, the successor of Mr. Calhoun in the U. S. Senate. Reports from the Episcopalian, Methodist, Baptist and Presbyterian churches showed great progress in evangelizing Negroes in Virginia. The Convention's program is well shown in a section of a committee report which states: "Indeed we look upon the religious instruction of the Negroes as THE GREAT DUTY, and in the truest and best sense, THE FIXED, THE SETTLED POLICY OF THE SOUTH." 66 There can be no doubt after

66. Princeton Review, Oct., 1845. 
an examination of subsequent events that this policy was vigorously prosecuted.

We have mentioned the excellent quality of many of the free Negroes in the early part of the century and in the two previous centuries. This excellent standard failed to be maintained near the midway mark of the Nineteenth Centurv or our people looked on them with harsher eyes. Perhaps both suggestions are reasons for the unpopularity of free Negroes. Governor Wm. Smith in an executive message dated Dec. 7, 1846, ${ }^{67}$ calls attention to the facts that although the free Negroes and mulattoes constituted only about one-sixteenth of the population of Virginia (excluding foreigners), yet this small percentage contributed largely over two-fifths of the penitentiary convicts; although the free Negroes constitute only about one-tenth of the Negro race in Virginia, yet they perpetrated about six-sevenths of the crimes committed by Negroes. These statistics he thinks demonstrate the "moral degradation of the free Negro, the hopelessness of his reform, mischievous influence of his association, and the necessity of his removal. That he is a moral leper, is demonstrated." The governor believed that the free Negro was a ready ally for the Abolitionists and to remedy the evil, he proposed that there be a county option election to ascertain whether the county was willing for free Negroes to remain in it or not. So earnest was the governor in his desire to see the free Negroes deported, that he used language in exhibiting their pitiful condition which might well have been ascribed to the most fanatical of ardent Abolitionists. In his executive message of 1848. he said: "I ask how it is possible, that he can be other than he is, under the laws to which we subject him. ${ }^{68}$ Born in a hovel the companions of slaves, and the tool of the vicious white man, he naturally sympathizes with the degradation around him. By law, he is forbid to intermarry with the whites, to bear testi-

67. House Journal 1846-4\%, p. 10.

68. In all likelihood he referred especially to the act of $1847-48$. \$ 39 , p. 12. which was practically a re-enactment of former acts which forbade the assemblage of Negroes, mulattoes and free Negroes, for religious worship under the leadership of Negroes, mulattoes and free Negroes and also forbade them assembling for the purpose of instruction in reading and writing. 
mony against them, to learn to read and write, to preach the word of God to his fellows, to bear arms, and to resent insults from the white man. Many other laws of the same character are on our statute book; and in every relation from the cradle to the grave, he is never allowed to forget that he is an inferior race. By the providence of God, such is his destiny ; and according to naturalists, history, and the experience of all mankind. he is regarded as the third, or an inferior species of the race of man. But not content with this, by all the acts of legislation we force him below that position in the scale of humanity to which he is entitled. And is this state of things to continue forever?" 69 The governor followed this array of facts with a further argument for deportation. These conditions are here presented to demonstrate that in spite of many Christian charities performed for the Negro, still there was a woeful neglect. This neglect was recognized by many. Virginia did much, but she left much undone. Humarty speaking, every state and every society will always be subject to the same criticism. Perfect care for every person is still unrealized-except in Uitopia.

Travellers in Virginia, however, did not note so much of the neglect of Negroes as they noted that Negroes were not granted social equality. Sir Charles Lyell, F. R. S., in a trip through parts of America attended St. Paul's Episcopal Church at Richmond, Va., on Sunday, the 21st of December, 1845. On that day the rector announced that one of the side galleries would be set apart exclusively for the use of Negroes. This step was taken that the masters and servants should unite in worship. Sir Charles was not acquainted with our social life and he wondered why the slaves would not be raised to a better equality if they had been allowed to use the same galleries as the whites. It was then explained to him that because of the deference shown the whites by the blacks such a scheme as he proposed would be harmful to the Negroes in occupying good seats. He further notes the Sunday-schools for Negroes. ${ }^{i 0}$ Thackeray wrote from Richmond in 1853: "The negroes don't shock me, or excite my

69. Journal of the House of Delegates, Dec. 4, 1884, p. 21.

70. Lyell's Travels in the United States-Second Visit, Vol. I. p. 203, Sir Charles Lyell. 
compassionate feelings at all; they are so grotesque and happy that I can't cry over them. The little black imps are trotting and grinning about the streets; women, workmen, waiters, all wellfed and happy." $i 1$

Frederick Law Olmsted travelled through the South and tarried a while during 1853 in Virginia. He does not consider the moral and religious condition of the slaves gratifying, and objects that, "they are forbidden by law to meet together for worship, or for the purpose of mutual improvement." i2 And just such a sentence as that if given no further qualification is the cause of many Negroes believing to this day that nothing was done for their religious uplift during slavery. We have met young, supposedly educated Negroes, who thought that all their religious life as a race had been lived since 1865 . It is a painful state of affairs. As much of Olmsted's statement as is quoted above fails to note the always stipulated privilege of servants going to church with their masters or with parts of their masters families. It would have been unjust to this State to have left such a bald statement to be quoted by those who might readily have been susceptible to the principle stated by Julius Casar: "Men as a rule, gladly believe that which they wish." OAmsted's statement is qualified, however, in the next sentences with these words: "In the cities, there are churches especially for them, in which the exercises are conducted by white clergymen. In the country, there is usually a service after that for the whites especially in all the churches, which, by the way are not very thickly scattered." Of course, after the qualification is stated the first sentence loses much, if not all, of its virulent force, so far as it affects the religious life of the Negro, but sad to relate the first statement has been instilled into the minds of many without any reference to the succeeding qualifying statements that were made. In this same volume of travels a slaveholder tells Olmsted that in the matter of educational advantages the Negroes have religious instruction by means of persons reading

71. Thackeray's Letters, p. 168. Quoted in History of United States 1850-1877. James Ford Rhodes, p. 374.

72. A Journey in the Seaboard Slave States, by Frederick Law Olmsted. p. 113. 
the Bible to them and by means of preaching services held for them. Even though it was against the law for Negroes to meet unless a white man was present this law was not observed always everywhere. Overseers would look in on a service and then pass on. ${ }^{73}$ When Olmsted asked an old Negro preacher how he would like to live in New York, the darkey answered, "Oh, dey ain't no place in de world like Old Virginny for niggers, massa," - and so say they all to this day.i4

Francis and Theresa Pulszky after a visit to America epitomized the religious status of efforts to Christianize the slaves in these words: "The Gospel is preached to them; they have morally improved; the planters have never thrown any difficulty in the way of missionaries who instruct them in Christianity, except where they suspected them to be abolitionists; on the contrary. they pay the clergymen for visiting the plantations: they like to have pious slaves, because they are more patient and more laborious than the unconverted ones. They object sometimes to their being taught to read and write, that they may not be exposed to the inflammatory publications of the abolitionists; but the planters regularly give every assistance to the labors of the missionaries, who, of course, dwell most earnestly on the Christian obligation of the slaves to be subservient to their masters." is These writers also mention the pride which the planters feel in the unparalleled uplift is of a race in so few years. Benson J. Lossing tells of the faithfulness of some of George Washington's slaves and notes that he saw one of Washington's women slaves in later years at family worship at Arlington.7? Thus when travellers noted the religious care of the Negro-and they did not always record such things-even when they saw

73. Olmsted. pp. 106, 107.

74. Negro Organization Society Meeting in Richmond, Va, Nov. ith, 1913. Addressed by Gov. Wm. Hodges Mann, Dr. H. B. Frissell, Dr. Booker T. Washington and Major R. R. Morton, and others.

75. White, Red. Black-Sketches of American Society in the United States during the visit of their Guests. By Francis and Theresa Pulszky. Vol. II, p. 56.

76. Ibid., p. 56.

77. The Home of Washington and its Association. Benson J. Lossing, p. 339. 
them-during this century. they were compelled to see that the Iirginia masters were interested in the well-being of the Negro. and it was frequently demonstrated that intense activities were being maintained by missionaries in their behalf. In Norfolk there were four houses of divine worship for Negroes before 1860-three Baptist and one Methodist Episcopal, South..$^{-8}$ The First Baptist was on North side of Bute Street near Cumberland: the Second Baptist was on Northwest corner of Catharine and Charlotte Streets: the Third Baptist was on the West side of Hawk near Bute Street; the M. E. South was on South side of Bute opposite Union near Church Street. In Richmond there were two Baptist churches for Negroes-the First and Secondshown in directories up to 1856 , and in the book of that year a Methudist church appears. By 1858-9 another Baptist church was in existence. .9 The work done in these cluurches under white leadership was comparable from the Negroes' standpoint to time spent in a training school; and this training served them in good stead during the half century of independent church life since 1865.

That the Negro should have been subject to severe criticism was inevitable. He was an alien of a different race and color; far from home: he had little or no social caste-in short, a social pariah; his morals were immatured or loose; his ambitions were frequently stifled, and his home life too often undeveloped; his religion was hedged about by superstitions and his reactions in the presence of religious stimuli were exceedingly emotional. All in all, his sins of omission and commission were frequently facilitated by the mischievous of both races. Some believed that moral principle was almost entirely absent from among them; $"$ " others declared somewhat indiscriminately that "they lie, steal, blaspheme; are slothful, envious, malicious, inventors of evil things. deceivers, covenant breakers, implacable,

78. Norfolk Directory 1851-2; Vickery's Norfolk Directory, 1859. Also Forrest. Historical and Descriptive Sketches of Norfolk \& Vicinity pp. 326, 34t.

79. Richmond Directories $1850, \dot{\text { p. }} 45 ; 1852$, p. $155 ; 1855$, pp. 186, 187: 1856, pp. 254-256; 1858-9, pp. 38, 39, 1860, pp. 44. 45.

80. C. W. W. Gooch, Esq., of Henrico County, in a prize essay on "Agriculture in Virginia." See Harrison \& Barnes, p. 103. 
unmerciful, greatly wanting in natural affection, improvident, without understanding and grossly immoral." 81 It was pointed out that marriages often availed little, the Sabbath day was frequently spent in unholy ways, Negro church members frequently had to be disciplined for lapses and many of them appeared without hope in this world or the next. Masters sometimes objected that they saw little use in training their slaves religiously since it was expensive to hire teachers, introduced men and principles that were liable to cause trouble, took up too much of the slaves' time, and, at last, did little or no good. since the Negroes would be hypocrites or worse men after conversion, and further that baptism really meant little more than the difference between a Negro wet and a Negro dry. These certainly represent the objections of only the worse masters, yet these objections must be mentioned to avoid suppressing part of the truth. Such opposition. however, did not avail to stop the good work in behalf of the blacks. If Negroes were not constant in their high professions, it did not necessarily follow that they were not sincere when they made such professions. Going to church, preaching. praying, singing, exhorting, relating experiences, performing baptismal rites, attending burials, etc., etc., had strong places in their affections and manifestly aided in the Christian growth of some of the faithful. For some such occasions meant little. Many of those, however, who partook of the religious offerings of the times before the war were far better fitted for the duties of life than some of those who in a later day surfeited on religion and were found to be unfit. Indeed. so strong has the emphasis been laid on the sterling characters of many good slaves and so fond are our fore-parents of recounting the virtues encouraged under the old system that the superiority of the religious life of the Negro during slavery is considered so obvious as to need no support by facts. Those most wonderful exhibitions of fidelity, and Christian character on the part of the slaves during the War of Secession proved beyond doubt that the religious training of their past had not been wasted. $\$ 2$ Good food, good treatment, re-

81. C. C. Jones, "The Religious Instruction of Negroes."

82. The American Negro. Wm. Hannibal Thomas, p. 41: "But the supreme and all pervading influence which restrained them was rooted in their religious convictions." 
sponsibilities, etc., all aided in preserving the homes of Virginia inviolate against the sable hosts living in the presence of our defenceless women and children. It is conceded, however, that perhaps the most important factor of all in bringing about that laudable end was their training in the knowledge of Christ.

Nor did interest in the Negroes' religious wel fare cease while the battles raged. It is true that most good Virginians went to the front, but the natural care-takers of the religious education of Negroes-the women-were left at home, and their sorrows in the death of loved ones and their prayers to God for success, seemed to spur them on to unusual zeal in breaking the "Bread of Life" to the hungering souls held as slaves. "We are very much occupied by our Sunday-schools, - white in the morning and coloured in the afternoon" 83 is the record that one person leaves and such records are even yet frequently attested by word of mouth. Besides the work done by Virginians to aid in the religious development of Negroes, the work done by Northern missionaries must not be forgotten or underestimated. As early as August, 1861, the American Missionary Association sent Rev. C. L. Lockwood to Virginia to work among the "contrabands." By October of the same year organized work had begun. The Assistant Secretary of War, U. S. A., and Generals Butler and Wool promised the missionaries hearty co-operation. The work of organizing Sunday-schools, and church societies. and the work of inculcating habits of industry and thrift went hand in hand. The Negroes were in need of books and clothing, but they did not long remain in need of an excellent Sundayschool meeting place since they used the mansion of Ex-President John Tyler situated at Hampton.84 "The Villa Marguerite," as this beautiful home was named, by Mrs. Julia Gardiner Tyler, no longer heard the serenades of the band from Fort Monroe in honor of an Ex-President of the United States, but was converted into a religious training school for contrabands of war. ${ }^{85}$ In 1864 an extract from the Corresponding Secre-

83. Diary of a Southern Refugee, during the War. By a Lady of Virginia (Mrs. Judith W. McGuire), Jan. 19th, 1863.

84. Hampton and its Students by Miss M. T. Armstrong, pp. 14-16. 85. This fact vouched for by personal letters from Dr. Lyon G. Tyler, President of William and Mary College, and a son of Ex- 
tary's report of "The Friends Association for the Aid and Elevation of the Freedmen" shows that the Negroes near Fort Monroe had built a plank church and they considered it so sacred that it seemed that they almost worshipped the building. It further stated: "Their religion is one of faith, and yet one of strong excitement and feeling. They do not think they have had a good time unless they can make a noise. . . . Their prayers are repetitions and much the same, and yet put up in much earnestness, and as we believe, have called down the blessings of God." so Besides the American Missionary Association and the Friends Association the other churches of the North showed an active interest in this work. In 1862 the Executive Board of the American Baptist Home Mission Society had voted to enter the Southern fields "as the providence of God might open to them." Advances were made during 1863 and 1864.87

Virginians were very proud of their Negroes and well they might have been. Virginia Negroes were the picked of the picked. In the first instance, away back in Africa only the able ones survived the wars or marauding expeditions in which they were captured in their African homes, and after which they were marched as captives to the sea-coast, to be sold to slave dealers. 88 The African slave sellers had made the march to the sea at a rapid pace and this constituted a severe test in itself. since the captives had been given little food on the march; of course, those the conquerors did not attempt to bring to the coast had been murdered on the spot. The slave dealers then subjected the captives to a minute examination and if defects were found the unfortunate rejected came to a terrible end. If accepted, the captives were then offered to ship captains engaged in supplying the American slave markets. The white slave traders in turn, would be particular that only good ones

President John Tyler. "The Villa Marguerite" is now the Dixie Hospital in which colored girls are in training to become nurses.

86. See "Quaker Pamphlets" in Park Avenue Meeting House Library-Report of Susan H. Clark, a teacher at Mill creek, near Fortress Monroe, Va. Fifth Month, 11th; 1864.

87. Hist. of the Richmond Theological Seminary, C. H. Corey, pp. $52,53$.

88. See Tillinghast, The Negro in Africa and America, pp. 106-112. 
were bought, since weak ones would hardly be able to undergo the horrors of the "middle passage" and if they did survive in a weakened state no buyers could be found in America. Thoughts of the "middle passage" with its pollutions, arise as a stench in their nostrils to this day and lucky indeed were the Negroes who happened to put feet on the soil of Virginia after that gruesome ordeal. The slave owners in America next subjected them to a rigid test and by this time it was well assured that the slaves were hearty specimens physically. Of course, none of these tests dealt with their intellects or morals; these were dealt with by the inland slave trade. If a Negro on a Virginia plantation proved unmanageable, liable to cause further trouble, or even especially vicious, there was one road he must travel-South. To be sold South was a prospect which was exceedingly hateful to Virginia Negroes, and to many death would have been almost preferable. A check on their evil deeds thus existed in the form of an understanding that wrongdoing meant their sale to cotton and rice growers in the far South. Virginia Negroes were further selected by an efficiency process. The house Negroes, in opposition to those in the quarters, were further selected, because of intelligence, neatness, docility, etc., and from the house Negroes all agree that we get the noblest specimens of Negro manhood and womanhood which came through slavery times. The Negroes were always imitative and the house Negroes of Virginia were thrown into as choice an environment as could be found anywhere. That they were "quality" Negroes after this series of selective processes needs no further elaboration.

Among the distinguished Negroes who did religious work worthy of any time in the world's history, while living in antebellum days, we have chosen several for particular mention at this time. George Lisle was a Virginia Negro, born about 1750 , and served as a body servant to a British officer. He preached as he moved about the country and a man that he baptized, Rev. Andrew Bryan, organized one of the first Negro churches in America, a church in Savannah, Ga.. about 1788. In the island of Jamaica, Lisle did notable work in directing missionary efforts toward that island and was himself the pastor of a church consisting of nearly 4,000 members. ${ }^{89}$

89. The Negro Church, pp. 33, 34. 
Lott Carey was also a Virginia Negro, born a slave in Charles City County. He was born about 1780 and moved to Richmond about 1804 and there worked in a tobacco factory. His life was very wicked until he joined the First Baptist Church. This event occurred about $180 \%$. The church encouraged him to be a minister at a later date. Lott learned to read, stuclied hard, acquired much knowledge from a wide range of reading and was licensed to preached. He decided to become a missionary to Africa, announced his intention at a night school. afterward refused a $\$ 200$ raise in salary which would have made him the recipient of $\$ 1,000$ per year provided he remained with his employer. He preached in the First Church before leaving. and made a good impression. Collin Teague, an excellent Negro. went with him to Africa on the ship "Nautilus" which left Norfolk for Africa on Jan. 23d., 1821. Lott became a government official in Liberia. did a good work in helping the people in his new home and was mortally injured in 1828 while casting cartridges to defend his colonists against the natives. ${ }^{91}$

John Stewart was born of free parents in Powhatan County, Virginia. His parents were good members of the Baptist Church, but John grew up as a sinner. While going from his home to Marietta, Ohio, he was robbed of all his money and "this circumstance brought him to reflect seriously on the state of his soul." $\mathrm{He}$ became a Methodist and preached among the Wyandott Indians as early as 1816, near Lpper Sandusky, Ohio. His work was very influential and much appreciated. ${ }^{91}$

Although John Chavis was a North Carolina Negro by birth he spent part of his life in Virginia at Lexington. By a court record of 1802 it is shown that he had been a regular student in Washington Academy, now Washington and Lee University. At Princeton he studied privately under Dr. Witherspoon. Chavis became a licentiate in the Presbyterian church and preached. His school in which he taught both, whites and blacks was justly famous for his scholarship and his pupils fame in later years. ${ }^{92}$

90. Lives of Virginia Baptist Ministers-James B. Taylor, pp. 396444.

91. Missionary Pioneer-Memoir of John Stewart. Published by Joseph Mitchell.

92. The Negro Church, p. 35: Ballagh. History of Slavery in Virginia, p. 110. 
The case of Chavis was reversed in Henry Evans. Evans was a Virginia free Negro but his distinguishing work was done in North Carolina. About the year 1800 Evans began to preach to the blacks at Fayetteville and in spite of persecutions he continued his good work. His good life and able messages won to his side the white people and eventually his work became the basis of a Methodist Church of mixed membership. Bishop Capers said of him. he "was undoubtedly the best preacher of his time in that quarter and was so remarkable as to have become the greatest curiosity of the town insomuch that distinguished visitors hardly felt that they might pass a Sunday in Fayetteville without hearing him preach. ${ }^{93}$ His own words in the presence of death uttered as he stood tottering by his pulpit are eminently worthy of being preserved: "I have come to say my last word to you. It is this: None but Christ. Three times have I had my life in jeopardy for preaching the gospel to you. Three times have I broken ice on the edge of the water and swam across the Cape Fear to preach the gospel to you; and, if in my last hour I could trust to that, or anything but Christ crucified, for my salvation, all should be lost and my soul perish forever." Soon afterwards this good man died.

"Uncle Jack," the African preacher-perhaps the most interesting character developed before the war-was kidnapped from Africa at the age of seven and brought to America in one of the last cargoes of slaves sold into Virginia. He was bought by an obscure citizen of Nottoway County, Virginia. ${ }^{94}$ In those days there was little religion in that section and chances seemed poor for a Negro to develop a strong Christian character. Jack was densely ignorant and perhaps would have remained so, had not a man stirred him by predicting that the world would come to an end in a few days. The Negro was then about forty years of age, yet he set to work to learn his letters with his master's children as his teachers. As soon as the key to knowledge was obtained he applied himself diligently to the Scriptures and soon memorized large portions of the sacred writings. Revs. John

93. McTyeire, History of Methodism; The Negro Church, p. 36; Bassett, State, North Carolina pp. 58, 59.

94 The African Preacher-By Rev. William S. White. 
Blair Smith, William Hill and Archibald Alexander were partly responsible for his conversion and were helpful to him in gaining further knowledge of Scriptural exegesis. "Uncle Jack" was after a time prepared for an examination to enter the ministry. He successfully passed and was ordained as a minister of the Baptist church. His charge was in the country and he did his work well. His reputation was so favorable among the whites that when some dispute arose among his owners concerning their property in him the neighbors of the old preacher, to get it settled, paid for his freedom, ${ }^{95}$ and set him up in a little house and lot. Plantations were never closed to him and masters and overseers welcomed him as a friend. A Negro wrongdoer once begged to be punished by his master rather than be sent to " $\mathrm{Ln}$ cle Jack" to be disciplined. As a Baptist he was broad-minded and even welcomed the Presbyterians into the county. He spent his time learning and imparting knowledge. His life was a fearless fight for the truth. Once a Negro preacher named Campbell caused a schism among Negro Baptists by contending that God revealed Himself to the Negroes through the Holy Spirit and not through the Bible; ${ }^{96}$ also that it was a sin to eat pig's meat. The old African preacher went to the place where Campbell was preaching and defeated him in open debate. "Uncle Jack" used excellent English and had a marvelous faculty of illustrating his point with incidents drawn from Nature. His language was often pictorial, yet very pointed. His services were widely required for the funerals of slaves. Sometimes he went as far as thirty miles on such a mission. It would be impossible to fail to mention the sincere humility of Jack. He did not dissemble; he was true. On one occasion he refused a good black suit because he did not want to dress better than his fellow Negroes and because he feared that he would think about his fine clothes even in meeting. After the laws forbidding Negroes to preach had been passed he stopped and would not

95. A similar case was related to me by Mr. Frank Armistead, a lawyer of Williamsburg, Va.

96. A Negro preacher living at Doswell, Va, recently told me that before the war Negroes in his neighborhood thought that white folks had no religion because they got it from the Bible instead of by direct revelation, as Negroes thought they got theirs. 
preach again even though he was assured that he would not suffer from that law. He thought his preaching "no better than the ringing of an old cow-bell and ought to be stopped." In reality, others considered him the best preacher in that section of the country. Whites and blacks leamed from him, and he was so well thought of that a regular place was reserved for him during family worship at Mountain Hall, the home of Dr. James Jones of Nottoway. Dr. J. H. Rice wrote of this Negro preacher in the Virginia Literary and Evangelical Magazine: -Jack possesses the entire confidence of the whole neighborhood in which he lives. No man doubts his integrity, or the sincerity of his piety. All classes treat him with marked respect. Everybody gives unequivocal testimony to the excellence of his character." He died at a good old age and his death was sincerely mourned by all. We have sketched the life of this unusual man at some length in order that we might show some of the possibilities under the old régime. It is true that only an exceedingly small number did, or ever will, surpass this noble character because few did or will pay the price that he paid. His life of humility and unselfishness is monumental and stands as an example to many in the ministry even at the present time. It is interesting to note that "Uncle Jack" and Nat Tumer-both preachers-were contemporaries. It is often pointed out that society drove Nat Turner to despair and caused him to be a ruthless murderer, but it is as frequently overlooked that the same society which made one man's name detestable among right thinking people, made of the other man, "Uncle Jack," one of the noblest characters in Virginia Negro history. His generous white friends have preserved his name as one of the proudest memories of Negro religious achievement. It does seem that our literature would be poorer indeed without the descriptions of such excellent characters as "African Bella," "Aunt Betty," "Springfield Bob" Smith,97 "Mammy Harriet" 98 and "Aunt Jenny." 99 To many, these characters would be passed as be-

97. Sketches of Old Virginia Family Servants, by a Grand-Daughter of General Nelson, pp. 25, 54, 61.

98. Memorials of a Southern Planter, Susan Dabney Smedes.

99. Virginia: Past and Present. By Elizabeth Lee, pp. 19, 20. 
neath their dignity to notice, yet their struggles, apparently insignificant, were as heroic fights for character as any that we meet at present. Christianity did much for them.

Other prominent Negroes were born in Virginia during the period of slavery, such as John Jasper, James H. Holmes, and Booker T. Washington, but because their principal achievements came in the period after the war, we shall reserve further mention of them until later.

The progress which the Negro made during the first sixtyfive years of the Nineteenth Century was without parallel, up to that time, in the world's history. Slavery lessons were taught in a hard school, but they were lessons taught well. Half-way efficiency could scarcely satisfy the Anglo-Saxon. Money was liberally expended that the Negro might be provided with the benefits of religion. That the expenditures of those days were not so great as those of the present need not occasion surprise. That so much time, energy and money were expended does $\propto c-$ casion some. The benefits of slavery were vastly more, we believe, to the advantage of the Negro than to the white man. ${ }^{2}$ Some writers at present seem to assume that the Negro was as civilized when he was imported into Virginia during the seventeenth century as he was at the end of the War of Secession. Such bathos is unendurable. The more manly and fair-minded attitude is that taken by Booker Washington when he said: "I know, despite all the conflicting opinions, and with a full knowledge of all the Negroes' weaknesses, that only a few centuries ago they went into slavery in this country pagans, and they came out Christians: they went into slavery so much property, they came out American citizens: they went into slavery without a language, they came out speaking the proud Anglo-Saxon tongue; they went into slavery with the chains clanking about their wrists. they came out with the American ballot in their hands." If the Negro had gained nothing in slavery except knowledge of the English language, some understanding of government, the habit of labor, and the Christian religion, his experience would have nevertheless been invaluable. That the Negro has achieved so much as a race is a just matteraf pride, yet

1. Meade, Old Churches, Vol. I. p. 90

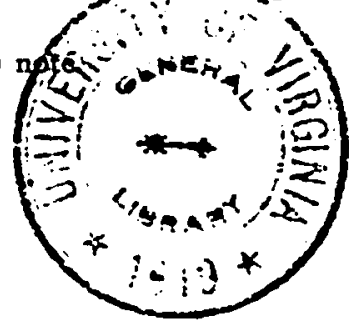


history shows that the Negro has had more done for him voluntarily by the Caucasian race than any other race ever did for another.

A host of witnesses testify to the opportunities for building strong character structures during slavery days and another host will testify that the opportunities were frequently grasped. All praise to the many Virginia Christians, both white and black. who cheerfully though frequently through intense suffering, aided in the great service of endeavoring to help a race born in darkness see the light. Few Negroes now living have given its due to the work done for their religious development during slavery; few whites have known enough about Negroes since then, to give them their due. Niany Negroes remember the laws prohibiting preaching by Negroes, or those prohibiting the Negroes to learn to read and write, yet few indeed seem to remember that the white preachers and Bible teachers stepped into the breach left by the absence of black preachers, and fewer yet seem to remember the circumstances that influenced the passage of the reading and writing laws, or the fact that such laws were practically dead letters on every plantation where the Negroes wished to read and white children were there to teach. Masters neglected many things yet they did try to understand their duties as masters and then tried properly to perform them.

A most excellent summary of religious effort for the Negro during slavery is presented in a pamphlet written by Gustave J. Orr, entitled "The Education of the Negro:" "I may say then, that it was the universal custom of all the churches of the South to receive slaves into full and regular membership, that the spiritual welfare of the colored church members was looked after with great solicitude by the official members of the different churches; that the slaves and their masters worshipped in the same houses, the only distinction being that different portions of these houses were assigned for occupancy to the two races; that. at Holy Communion, they partook of the same elements, administered by the same hands, at the same time, but always at different tables; that the ministers were universally expected to visit and labor with the slaves pastorally administering to them the consolations of our holy religion in sickness and burying them when dead; that in many places, special services, at least 
once on the Sabbath, were appointed for the exclusive benefit of the slaves; that very generally Sabbath schools were established for the religious instruction of the slaves in which they were taught orally from catechisms carefully prepared by the ablest divines of the different denominations;... . and lastly that it was the custom on many of the plantations for cultivated Christian mistresses to assemble, with their own smaller children, the younger servants of the household on the afternoon of the Sabbath, and to read to them and expound the sacred oracles, and drill them catechetically for the purpose of fixing in their memories the precious truths therein inculcated."

Just at the close of the war there were thousands of Negro church members and many of those were so active in religious work as to cause some modern Christians to blush when the works of the two are exhibited for comparison. Even though the Negro was frequently poorly equipped, he did try to take part in his church services. His efforts were crude and emotional, yet this is not very different from what the white revivals at the end of the eighteenth century showed.2 Ignorance is never so restrained under excitement as is culture. / The Negro's wrestle with the Devil was very real; his religion was a terrific reality, and even if he did dream dreams and see visions, we need not be too sure that his religion was not the kind best surted for his comprehension at that time. "In his simple, earnest, affectionate and believing heart, in his ecstasies of love for 'Mas' $r$ ' Jesus, and in his tenderness to whatever appeals to him in nature, are principles of religion as saving, I venture to say, as the precise creeds, and the solemn and exact manners of the churchmen." 3 If his religion seemed to have much warmth and little intellect; ours seemed to have much intellect and little warmth. It is not at all certain that either of us has attained perfection in a religion for universal application. Both have valuable constituents.

Our forefathers lived in constant contact with Negroes and they knew their black friends and the blacks knew their white

-2. Adams, A Southside View of Slavery, pp. 53, 57, 171; also E. A. Pollard, Black Diamonds, pp. 34, 86.

3. Pollard, Black Diamonds, p. 87. 
friends. The Negro's ideals were raised by living in contact with a people famed for idealism. Indeed, the Negro witnessed the physical vanquishment of the South by arms; he never did witness a Southerner declare that principles can be decided by force: he saw Virginians overcome in combat: he did not see them forsake their trusts. The contact with men of honor had a positive influence over many lives of Negroes before the war. A change came. This contact is almost entirely gone now. The best white people rarely see the best Negroes. The best Negroes are disturbed by the worst whites. The opposite ends of the races meet. Our forefathers had tremendous problems on their hands, yet they measured up to the full statute of manhood by standing for principles and caring for the religious welfare of their slaves and Negro employees. They undertook this task as though they were seeking a pearl of great price. The pages which are to follow will show what their training meant to the Negroes when they became independent of white guidance and restraint. 
1865-1913.

If the religious life of the Negro in Virginia be compared to the growth of wheat, we may say that during the seventeenth century the sowing was done; the first part of the eighteenth represented the period of little growth during the winter; from the middle eighteenth to the end of that century is like unto spring with its consequent new life; the first sixty-five years of the nineteenth show the wheat "in the boot," and the latter part of that century and the beginning of the twentieth show the harvest of golden grain, some seed bearing thirty. some sixty and some a hundred fold. It is gratifying to be living in the time of harvest. The care and intelligent oversight of the past must now secure their rewards.

Slavery was not a beautiful dream; it was a tremendous reality. Even though many benefits were derived by those held in bondage, yet we must ever be mindful that man and beast are restive under restraint and detest the enthralled condition. Some very placid men and a few very quiet animals seem to suffer less inconvenience than others of more liberty-loving dispositions but the love of freedom is deep-rooted. This desire for freedom seems to come to man with visions of adolescence and we do the greatest violence to nature when man's will is held in bondage. To enslave the body is bad; to enthrall the will is worse. The Negroes had leamed during slavery days of the Israelites. and their Egyptian bondage, of the Egyptian task master's lash, of the wanderings in the Wilderness, and the final deliverance of a land into their hands, and we can be very sure that in the secret meditations of many slaves it was thought that their own condition was identical with that of the Israelites of old. Though many slaves were true to their masters and some masters were true to their slaves ${ }^{1}$ even after the arbitrament of the

1. We append an extract from the diary of John B. Minor. dated May Sth, 1865-less than a month after the surrender of Lee and before the bruised bodies and spirits of Virginians had recovered from the shocks of warfare: "At a meeting of gentlemen at Dr. Maupin's to-night it was a subject of consideration what should be done in 
sword had made it evident that human bondage was no longer to be tolerated in the United States, still most Negroes felt that they, like the Hebrew children, were released from an Egyptian bondage, and were entering into the Promised Land. Their songs indicate it; their actions when no sounds were heard. spoke louder than human utterance. Their new freedom was soon tried out. One of the most natural channels of expression for this new found freedom was to indulge in religious meetings, as frequent and as long extended as the black worshippers pleased. During slavery they were limited in time because the masters wanted their best service on the next day. Now, Negroes, good, bad and indifferent. turned themselves loose on this devoted Commonwealth as preachers or exhorters, and religious orgies were held, the equal of which this State had never known before. It was only natural that such excesses should have followed. It is a high tribute to the race that they survived such leadership and have now developed a different ideal of the ministry.

For the first two years after the war, the status quo of the social position of the Negro was suddenly changed in his own eyes from that which existed before and during the war. Much was heard of being treated as a man and brother." The Northern missionaries, "scalawags," "carpet baggers," and Negro preachers were largely responsible for this inflation. During these years the Negro, under the influence of the same and other misguided or false friends, became so assertive that he rapidly lost caste in the eyes of the best elements among the whites. Nothing could have been much more tragical in its

respect to the Negroes and I found it was the almost universal sentiment to abandon them to their fate. They were conscientious and humane men who expressed this sentiment, but I cannot see how we can reconcile it with our duty thus to whistle them down the wind to prey at fortune.' as soon as the prospect of profit or advantage to ourselves is taken away. My present purpose is to retain and support and care for mine as long as they behave themselves and $I$ am able to do so and I pray God to enable me to fulfil my design to the good of the bodies and souls of the poor hapless creatures."

2. The following portion of a verse from the Bible was widely quoted: "Have we not all one Father? Hath not one God created us?" Malachi 2:10. 
consequences for the Negro, since many of the ills that his black flesh is now heir to have come upon him as a consequent of his fatal choice. The best elements among the whites remain to this day; his false friends departed. Even though the farce of forcing a ballot into the hand of the ignorant Negro nettled the white men of Virginia who would not brook the political supremacy of their former servants, yet there was always something within which made the whites anxious to do good to those creatures who were rather "sinned against than sinning." Such men as the Rev. J. W. Hunnicutt and Joln Hawxhurst, both radicals. had absolute control of the Negro voters and under such leadership the political situation became distressing to lovers of good government. This proud State, Virginia, then witnessed a spectacle which it never saw before-the reins of its government in the hands of Negroes. For one dizzy moment "the bottom rail was on top" and joy among the blacks was unconfined. Perhaps the fact that Reconstruction never became so severe in Virginia as in other Southern States helped to soften the Caucasian heart. There was also the chance in every good deed done to aid the Negro religiously, to prove to the world that the care and oversight maintained before the war were not the results of sheer self-interest, but were oftenest performed from the best of motives.

While the smoke of battle was still rolling over the hills of Virginia and before the great battle at Gettysburg had been fought or the siege of Vicksburg had proved successful, "the members of St. John's Church (African M. E. South, at Norfolk, Va.), expressed their dissatisfaction with existing conditions, and the Official Board May 4, 1863, voted unanimously to annul the discipline of the M. E. Church South." 3 With the aid of the Federal officer, George Dix, the church property was secured for the congregation of blacks and the membership agreed to join the Baltimore Annual Conference of the African Methodist Episcopal Church. Largely through the agencies of Professor Woodbury, superintendent of the government school in Norfolk, and Bishop Wayman, the decision to become members of the A. M. E. communion was consummated. The work

3. Butt, I. L. African Methodism in Virginia, pp. 32, 33. 
for this denomination in Virginia was not independent at first. but was carried on through the Baltimore Conference from 1864 until May, 1867, when the Virginia Conference was organized at Richmond, Va.

In the face of the foregoing facts which so conclusively indicate a real secession of African Methodists from the Methodist Episcopal Church, South, how is it possible that a talented Negro writer should have so distorted the whole spirit of Virginians and perhaps that of the whole South, concerning the affiliation of Negro members, as to write: "The result of the war was the complete expulsion of Negroes from white churches. Little has been said of this, but perhaps it was in itself the most singular and tremendous result of slavery. The Methodist Church South simply set its Negro members bodily out of doors. They did it with some consideration for their feelings, with as much kindliness as crass unkindliness can show, but they virtually said to all their black members-to the black mammies whom they have almost fulsomely praised and whom they remember in such astonishing numbers to-day, to the polite and deferential old servant, to whose character they build monuments-they said to them: 'You cannot worship God with us . . . . Flagrantly unchristian as this course was, it was still in some ways better than the absolute withdrawal of church fellowship on the part of the Baptists or the policy of the Episcopalians which was simply that of studied neglect and discouragement which froze, harried and well nigh invited the black communicants to withdraw"? We know that the establishment of the Colored Methodist Episcopal Church in 1870 was really best for both races, yet how can it be correct to speak of setting people out of doors when they voluntarily went out? Is it fair to whites or blacks so to emphasize facts as to distort the truth? Is it not well known that when the Colored Methodist Episcopal Church was set up the buildings used exclusively by Negroes before 1870 were given to them, and no desire was shown to mistreat any or set anybody "bodily out of doors?" History cannot be sacrificed for the sake of rhetoric.

4. The Negro in the South, p. 173. from chapter entitled "Religion in the South," by W. E. B. Du Bois. 
We shall next see whether the white Baptists were guilty of neglecting the Negro members or not. A very valuable manuscript letter preserved in the Archives of the State Library at Richmond, Va., written by Horace C. Hovey to C. Poindexter, describes some of the events of that memorable Sunday after the occupation of Richmond by the Federal Army. It relates that the Federal officers decided to encourage church services on that day but resolved to supervise them with delegates from the Christian Commission. The morning service at the First African Church passed without incident. Mr. Hovey, one of the supervisors, heard. however, that there was danger of disturbance in the afternoon and when he arrived he found Dr. Ryland, the white pastor, talking to some excited colored soldiers. The troopers were Abolitionists from Massachusetts and objected to Dr. Ryland as a Secessionist and because he had advised the slaves to stay with their masters. Mr. Hovey showed to these soldiers the good sense of the advice given and it was agreed that the congregation should decide whether their regular pastor should preach or some other person. The congregation voted in favor of their own pastor; the doors were opened and the meeting concluded without further disturbance. We believe that such decisions may have continued but for the influence of agitators. It was soon evident that the day of the white pastor's desirability for the Negro pulpit had passed. Speaking at the Centennial of the First Baptist Church, Dr. Ryland said, concerning giving up his great work of twenty-five years: "At the close of the war, the Constitution and rules of the order were so far modified, as to adapt them to the new relations which the colored people sustained to society. The Pastor then offered his resignation, from a belief that they would naturally and justly prefer a minister of their own color. This resignation was proposed and accepted with mutual kindness and good will." "

In General Associations from 1867 to 1874 an active interest was manifested by the Baptists, yet practical efforts were sadly

5. The First Century of the First Baptist Church, pp. 263, 264. Also see a short History of the Gilfield Baptist Church of Petersburg, Va., 1803-1903, by Richard Kennard. 
handicapped by lack of means throughout the impoverished State. At the Lynchburg meeting of the General Association in 1867 the Committee on the Instruction of the Colored People said: "Our obligation to impart religious instruction to the colored race is unquestionable. It has long been acknowledged and acted upon by this body. . . . . We shall be culpably inconsistent, if. while making the effort to send the message of salvation to Africa, we neglect to proclaim it among the Africans in our midst." This preamble was followed by suitable resolutions. At the same Association the report of the Sundayschool and Publication Board for Virginia showed progress in distributing Bibles to the Freedmen. In 1868 the Committee on Instruction reported to the General Assembly at Alexandria: "We feel now as we have always felt, the deepest interest in the spiritual welfare of this people. Recent events though weakening our influence with them, have not impaired our obligations to give them the word of life, etc." T The General Association meeting at Norfolk in 1870 instructed the Sunday-school and Bible Board to give attention to "the establishment and maintenance of Sunday-schools among the colored people of this State." $s$ At the morning session of the General Association June 1st. 1871, J. B. Watkins, Corresponding Secretary of the Sunday-school and Bible Board, declared that the Board had endeavored to carry out the instructions of the last Association concerning establishing colored Sunday-schools. Rev. T. W. Sydnor, D. D., had been appointed to undertake the work and "traveled hundreds of miles; visited churches and Sunday-school Conventions; delivered sermons and addresses; distributed Testaments. and organized directly seven colored Sunday-schools, besides influencing the establishment of others, and encouraging and strengthening existing ones." The good work of Dr. Sydnor continued during the year succeeding the last Association. We find a very interesting entry in the report of the missionary of the Sunday-school and Bible Board to the General Association at the Staunton meeting in May, 1872, which reads: "One great

6. American Baptist Year Book 1868.

7. Ibid 1869.

8. Ibid 1871 . 
mistake that the colored people have made has been to hold political meetings in connection with their religious assemblages. I endeavor to discourage this in every suitable way, and I find that my presence at their meetings sometimes embarrasses the politicians very much." In 1873 because of insufficient funds it was necessary to dispense with the very excellent services of Dr. Sydnor but the Board pledged to do its best. The Domestic Mission Board at this same Association reported that much labor had been expended on the colored people with happy results. In 1874 the General Association was gratified to state that the American Baptist Publication Society had appointed Rev. Walter H. Brooks, colored, of Richmond, as general Sunday-school missionary among Negroes in Virginia. The cumulative evidence of the above statements would indicate that there was indisputably a vital interest in the religious welfare of the lately enslaved race. In 1879, a committee of eight appointed in the General Baptist Association "to consider and report on the propriety of cultivating more intimate relations with the colored Baptists of the State ${ }^{9}$ brought in its recommendations that five corresponding delegates to the Colored Baptist Convention be appointed, and seats be provided at all times in the White Association for invited delegates from the Colored Convention and provision be made or caused to be made for the "hospitable and appropriate entertainment of said colored delegates during the sessions of the Association ;" further, that the District Associations endeavor to promote kind relationships between the races and the evangelization of the blacks; further, that white Baptists aid the black Baptists in acquiring knowledge, to increase their efficiency by means of ministers' institutes; etc., and lastly, that the General Association should aid any influence that made the desired betterment of the religious life of Negroes. ${ }^{10}$ These references prove anything but an "absolute withdrawal of church fellowship" on the part of the whites.

The matter looks different from another angle. We see that the Negroes soon after the war seceded from the Baptist Church and formed their own ecclesiastical organization, had their own

9. Minutes of Virginia Baptist General Association $1879 \mathrm{sec} 13$.

10. Minutes of Virginia Baptist General Association $1879 \mathrm{sec} 13$. 
preachers and worshipped in their own churches. ${ }^{11}$ The whites offered no objection and in reality encouraged the Negroes in this course. Before the close of 1866 a number of Negro Baptist churches of the South had formed a connection with Northern Baptist societies and in August, 1866, a Convention known as the American Baptist (African) Missionary Convention met at Richmond, Va.12 In Alexandria, Culpeper, Fredericksburg, Williamsburg, Portsmouth and Richmond, schools were maintained which offered special opportunities for training a Negro ministry. ${ }^{13}$

On May 9th, 1867, the Virginia Baptist State Convention (Colored), was organized in the Zion Baptist Church at Portsmouth. Va., by members of the Norfolk Union Baptist and Colored Shiloh Associations. The first anniversary was held in the Bute Street Baptist Church at Norfolk. May 13th, 1868.14 It would seem that this Negro ecclesiastical organization, instead of suffering from neglect-as the Negro Baptists are said to have suffered-had had no desire to have any dealings with the white organization and certainly had made no formal report to the whites of their existence as a church body up to the time of the following communication: "The Virginia Baptist State Convention to the General Baptist Association of Virginia, in its 48th Annual Session in the city of Petersburg, Va., 1871; Dear Brethren-We greet you with Christian salutations: We are a body of Baptists organized into a State Convention in 1868, for missionary work in this, our noble State of Virginia.

"Our sole object is the diffusion of the Gospel of Christ and the interest of his kingdom, by sending out missionaries, planting and training churches, and assisting feeble Baptist churches in the support of their pastors throughout the State of Virginia as far as lieth within the ability of the Convention.

"We are adherents to one faith, one Lord and one baptrsm, yea. to all the vital principles of the great Baptist family, therefore, we respectfully ask correspondence with you in the laudable work of evangelizing this our State. For opening cor-

11. Peyton. History of Augusta County, p. 88.

12. American Annual Cyclopedia, 1866, p. 58.

13. Ibid. 1867, p. 87.

14. American Baptist Year Book, 1869. 
respondence with us, we send with this letter our beloved President, Richard Wells, of Richmond, and pastor of the Ebenezer Church in said city. Our Convention recently met in Lynchburg. We have not our statistics for 1871 at hand. Our statistics for 1870 stand: churches 37; Baptisms 1,800; Total membership 22,387. We received several additions at our recent annual session. We have a Sabbath-school Union under the auspices of this Convention. It is composed of 26 schools and 3,100 scholars.

"Pray for us dear brethren; may the love of Christ which passeth all knowledge, dwell richly within your hearts.

"Receive our beloved President and representative in love, and may the blessings of Christ, the great head of the churches. ever preside over you, direct your deliberations and work for our common Master is our prayer, Amen.

"Done by order of the above named Convention, in its fourth Annual Session in Lynchburg, Va., May 1871.

"Richard Wells, President,

"E. Carprew, Corresponding Sec'y." 15

The committee from the Baptist General Association of Virginia, with the eminent Dr. J. B. Jeter as chairman, to whom the above communication was referred, respectfully reported that the right to organize and govern churches and provide for all necessary arrangements for worship and prosperity was freely acknowledged to be the privilege and right of the colored brethren; congratulations were sent to the Convention because of their successful work in spreading the Gospel, and the kind, Christian sentiments expressed in their communication were heartily re- ciprocated; proffers of aid in their pious labors were pledged in ways deemed expedient. It was finally resolved, (1) "That from considerations. which we need not specify and cannot control, we deem it inexpedient to enter into an interchange of corresponding messengers with the Convention; ${ }^{16}$ but (2) that the

15. Section 55 of Convention Minutes of General Ass'n of Virginia, preserved in Virginia Baptist Historical Collection. Richmond, Va.

16. Section 80 of Convention Minutes of Ass'n of Virginia, preserved in Virginia Baptist Historical Society Collection, Richmond, Va. 
President of the Association be requested to address a letter to the Convention, assuring them of our friendly regards, our hearty sympathy in their work, and our readiness to co-operate with them, so far as circumstances may permit, and that the clerk of this body be directed to forward to the Secretary of the Convention fifty copies of our minutes." Concerning matters which threatened to lead to social equality the whites were naturally very anxious at this particular time. but in matters strictly religious these men certainly had hearts filled with interest for the Negroes' betterment. That the refusal to interchange corresponding messengers was based wholly on the fear of such an innovation leading to social equality, we can gather from an article published in the September 7 th, 1871, issue of the Richmond Religious Herald of which Dr. Jeter was editor. He writes: "God has made the two races widely different; not only in complexion, but in their instincts and social qualities. Ilie take it for granted that it was not the purpose of the Creator that they should be blended. Nature abhors the union. . . . Religious and social intercourse are closely if not inseparably connected. Suppose we admit colored delegates to seats in our Association, we must, of course, allow them to sit where they choose, in juxtaposition with our wives and daughters, and the privilege granted to them must be equally granted to their associates. But if we invite colored delegates to seats in our religious bodies, we must invite them to share in our hospitality. We must maintain our consistency, receive them to our tables, our parlors, and our chambers, and the hospitality extended to them, must be granted to their wives, daughters and associates." The President of the Virginia Baptist State Convention expressed quite philosophically his disapprobation of such reasoning and then concluded with a touch of humor in the last sentence: "This Convention will not mourn at the noninterchange, nor slacken her progress but will move on trusting in that God who has no respect of persons. So far, she has proven herself to be void of prejudice, of colorphobia, of caste, of lines of demarkation on account of nativity, nationality, tongue, tribe or kindred." 17 In 1879 when political matters

17. See Minutes Va. Baptist State Convention 1872, p. 26. 
were again nearer normal and both races had come to a better understanding, we find the Christian love continuing and the social equality bugbear fading into insignificance.

The General Assembly of the Southern Presbyterian Church on November 15th, 1866, discussed the relation of the freedmen of that church to its white members. There were warm discussions throughout the South, some maintaining that there should be ecclesiastical equality in the matter of becoming deacons, ministers, etc., and the other party in absolute opposition to such a course. The dread of miscegenation was made evident during the argument over this ecclesiastical matter. ${ }^{18}$

In 1866 at the first general conference of the Methodist Episcopal Church, South, which met at New Orleans, La., the Negroes were granted the privilege of organizing into separate congregations, having their own preachers, etc. Undoubtedly, all of the Southern churches were interested in the spiritual welfare of the Negro, but they were somewhat bewildered to know just what was best to do. While the Southern churches were hesitating because of the lack of men and money the Northern churches little disturbed by the war were very active.

That the South should have been considered a legitimate field for missionary effort after the war need occasion no surprise. The work done by the Abolition societies and the influence of biased writings had badly misrepresented the religious conditions south of the Mason and Dixon line. Conscientious men and women from the North were ready at the close of warfare to gird on their Christian armor and go into the far country and struggle as did the Crusaders of old. They did struggle faithfully, in the face of tremendous odds. The full length portrait of the Northern missionary has never yet been faithfully painted. Southerners omit the Bible in his hand and depict only the ideas of social equality in his heart; Northerners show him as an angel in the midst of devils and forget his human attributes. Neither section now doubts his indiscretions; neither now impugns his motives. One section finds too much to condemn; the other sees only too much to praise. In the near future his work will be

18. Am. Annual Cyclopedia, 1866, p. 625. 
fairly evaluated and then the Negro will realize that the Northern whites and the Southern whites aided in forwarding the laudable religious amelioration of the Negro race in this Commonwealth. With much outside aid and with the Negroes helping themselves is it any wonder that they improved? Besides the work undertaken by the American Missionary Association and the Society of friends, which we have mentioned above. the Freedmen's Aid Society of the Methodist Episcopal Church, the Board of the Presbyterian Church North which put forth its "declaration in favor of special efforts in behalf of the lately emancipated African race" in 1865. and was later incorporated as "The Presbyterian Board of Missions for Freedmen of the Presbyterian Church in the United States of America," the Mission Boards of the Protestant Episcopal and Baptist Churchesall of these were active in evangelizing the Negroes and spent large sums of money to effect this noble purpose. ${ }^{19}$ Their motives were excellent but their manner of doing the work was certainly open to criticism. Their work co-ordinated in few places with work already done by the whites and it need cause no surprise that before many years had passed most of them had folded their tents and had gone to other fields of service. Many missionaries were astounded at the religious knowledge which some Negroes possessed. Indeed when the facts are carefully weighed it will then be known that the Northern missionaries did not erect a character structure de novo but built a showy superstructure upon foundations well-laid before the war. One planted and another reaped. It was not so much the type of religious teaching as their attitude toward the Negro socially that threw the work of Northern missionaries out of joint with previous religious efforts. In spite of pertness and flippancy, too often inculcated with religious instruction, the whole influence of the Northern missionaries was highly beneficial to the religious life of the Negro.

One of the foremost educational institutions which the Northern Missionary Boards founded has become a worthy work which is inspiring to better life and abler service many whose lives would not otherwise be influenced by the Christian religion. This institution is now called the Virginia Union University.

19. Missionary Review of the World, 27:660-66. 
In 1865, the American Baptist Home Mission Society through Dr. J. C. Binney opened the Richmond Theological School for Freedmen. In 1867, this school was reopened in Lumpkin's Jail by Dr. Nathaniel Colver and called Colver Institute. In 1868 , Dr. C. H. Corey. an educator and a man of great constructive ability, took charge. In 1876 , the school was incorporated as The Richmond Institute and in 1886 its name was changed to Richmond Theological Seminary. A union of the Richmond Theological Seminary of Richmond. Va.. and Wayland Seminary of Washington. D. C.. in 1899 resulted in the Virginia Linion University now located in beautiful stone buildings on spacious grounds in the suburbs of Richmond. The income of Virginia Union is derived from the interest on the $\$ 83.000$ endowment and contributions of the American Baptist Home Mission Society. The alumni of this institution have done much to redeem the Negro ministry of this state from ignorance. The preachers which they have graduated are usually leaders and have the respect of the communities in which they live.

The three departments of the University are: a College of Liberal Arts: a Theological Seminary; and an Academy with Manual Training. We shall be concerned only with the Theological Seminary. The requirements for admission for candidates for the degrees of Bachelor of Divinity are graduation from an approved college or equivalent work, or graduation from an academy, extraordinary ability and extra work assigned by the Faculty. Two years of Greek is prerequisite to the B. D. course. and a thesis is required from each candidate before the degree is conferred. These are the courses offered.

Original Language Course. FIRST YEAR.

First Term.

Second Term.

Biblical Introduction

Hebrew Language

Greek Language

Elocution and Speaking

Vocal Music

Sacred Rhetoric

The same except Greek Interpretation is offered instead of Greek Language. 
SECOND YEAR.

First Term.

Church History

Hebrew Interpretation

Homiletics

Elocution and Speaking

Vocal Music

Sacred Rhetoric
Second Term.

The same except Greek Interpretation is offered instead of Hebrew Interpretation and Church Polity is added to Homiletics.

\section{THIRD YEAR.}

First Term.

Christian Ethics

Christian Theology

Life and Teaching of Jesus

Elocution and Speaking

Sacred Rhetoric

Second Term.

The same except Pastorial Duties are offered instead of Christian Ethics and Electives instead of Life and Teaching of Jesus.

The English course in the Theological Seminary, as its name indicates, omits the Greek and Hebrew and replaces them with Principles of Interpretation and the Interpretations of the Gospels. Acts, the Epistles, Poets and Prophets, and Revelation.

A Special Course is given for those unable to gain admission to the regular Theological Courses and would undoubtedly do great good if more of the actively engaged but poorly prepared ministers would take advantage of it.

Virginians have good reason to take a greater interest in an institution that has done so much for the welfare of a portion of the citizens of this Commonwealth. Some of the faculty are white and others colored. Able men are in its faculty, and high ideals are inculcated under the Presidency of Dr. George Rice Hovey, a white gentleman of scholarly attainments and good judgment.

The Bishop Payne Divinity School had its beginning in 1878 because of the necessity of training Negroes to do religious work among Negroes. In 1884 the State Legislature incorporated it as an institution "for the purpose of educating colored persons for the ministry of the Protestant Episcopal Church." The School is located in Petersburg. Va., has four full Professors and a Principal, is the recognized Theological School of the General 
Church for educating Negro candidates for the ministry, and is supported by the General Board of Missions, the American Church Institute for Negroes, and the contributions of friends. One member of the faculty, the warden, who is also professor of Latin, Greek, Philosophy, History and English, is a Negro; the others are white. Two courses are offered: one for Deacon's Orders and the other for Priest's Orders. The first course includes Biblical Study, Hebrew and Greek, Prayer Book, Theology, Church History, English Language and Church Polity. The second course, for Priest's Orders, has prerequisite academic examinations. The studies in this course are: Apologetics, Exegetical Theology, Doctrinal Theology, Pastorial Theology. The English Bible, the Prayer Book and Christian Ethics. Most of these last-named courses run through three years and lead to the B. D. degree. The standing of this school is a credit to the well-known scholarship of the white Episcopal ministry. Naturally, the enrollment is small, but the students are very diligent while in the school and are eminently qualified to lead their race when they leave it.

The other prominent Negro theological institution in this State is the Virginia Theological Seminary and College located at Lynchburg, Va. In May, 1887, the Virginia Seminary, as it was first called, was founded by the Virginia Baptist State Convention (Negro) and in 1888 it was incorporated. In 1899, the charter was so changed as to add Theological and College Courses. It was at this time that the institution assumed its present name. The colored Baptists of Virginia, Maryland. District of Columbia. Pennsylvania, New England Convention, New York Convention, and New Jersey Convention supported the work and have endorsed it as their special educational work. The degrees offered in the Theological Department are Bachelor of Divinity and Bachelor of Theology with the distinction that the second course is without Greek and Hebrew. The three year courses are well filled with work.

This institution is now a school "of the Negroes, by the Negroes and for the Negroes." Its alumni have done meritorious service in the ministry and have reflected credit on their almo mater. The fact that its faculty is made up of Negroes entirely is very interesting. Is the time ripe for Negroes to assume con- 
trol of the education of their own race, or has the white man work to do yet in aiding this racial uplift? Virginia Theological Seminary and College has answered the question in one way, and Virginia Linion University and Hampton have answered it in the other.

We shall merely mention a few of the splendid non-theological institutions that are doing much for the welfare of the Negroes in Virginia. The Hampton Normal and Agricultural Institute is perhaps the most distinguished Negro school in America. It was opened in 1868 under the auspices of the American Missionary Association with General Samuel C. Armstrong in charge. In 1870 it was chartered and became independent of the Missionary Association. It is now inter-denominational and is doing the practical work for its students that makes them love truth and order and makes them hate hypocrisy and lawlessness. The Hampton graduate has an abundant incentive to live well. Dr. Hollis B. Frissell, a white man, and one of the really able students of the Negro question, is principal, and his faculty, instructors and officers are whites, Negroes or Indians. Bible instruction is included in the catalogued courses and other religious touches are given by the faculty teaching Bible classes, the influence of orderly prayer meetings. daily evening prayers, the active college Y. M. C. A., and the active King's Daughters. About ninety-five per cent of the students are professing Christians and these create a sentiment for a more intelligent Negro ministry wherever they settle.

The Virginia Normal and Industrial Institute situated at Petersburg, Va., is open to both sexes. It was founded by Act of the General Assembly of Virginia in 1882. A Y. M. C. A. and a Y. W. C. A. are in the Institute, as well as a large temperance society to which most of the students belong. All students are expected to attend the religious services of their choice on Sunday mornings in Petersburg. This State institution has done much to put well-equipped Negro teachers throughout Virginia and these carry, among other things, elevated religious ideals which they imbibed during their period of study.

Hartshorn Memorial College had its beginning in the Ebenezer Baptist Chuch, Richmond, Va., in 1883. In 1884, it was chartered by the Legislature. It is now well situated on West Leigh Street. 
in the same city, and is an institution founded for women only. That its aim was thoroughly Christian can be judged from the memorial inscription of its founder, Joseph C. Hartshorn. and also from a statement of its aim, as expressed in a catalogue of 1883-84: "It comes into existence with the single purpose of raising up a body of thoroughly educated Christian women as consecrated workers in the harvest field of the world. The homes, the churches, the Sunday-schools, the public schools, the mission fields of the Fatherland now open, are calling for cultivated Christian womanhood."

The St. Paul Normal and Industrial School was founded by a Negro Episcopal clergyman, Rev. James S. Russell. It is located in the heart of the "Black Belt" of Virginia and had its start in a little two story building, in which Mr. Russell held a small school in 1883 . In 1888 a Normal Department was added and since then this small beginning has grown to be a splendid institution with at least twenty-eight buildings, well-equipped, and doing a magnificent service in the training of Negroes, just where they need it most. This institution is commended by the General Episcopal Convention "to the thoughtful consideration and substantial aid of all Churchmen who desire that the 'Colored youth of the South' may be trained in the principles of education. industry and religion." The school is a credit to its founder as well as to those upon whom it has leaned for support.

No man can possibly estimate the good which these foregoing institutions have done for the Negro race in Virginia. Not only in the theological schools but also in the others the Bible is taught. The principles of religion which are inculcated in these schools are sane and sound and unemotional. It is the desire of the faculties of most of these schools not only to train their students in the three ' $R$ 's reading. writing, and arithmetic, but also in the three H's, head, hand, and heart. Their conception of the education of the Negro does not stop with the mind, but goes on to the body and spirit. The educated Negro is desirous not only to know something and do something, but more important still, he is filled with a desire to be something for the uplift of his less fortunate brothers. If we converse with prison officials, we find that the educated Negroes stay out of trouble; if we converse with doctors, we find that the educated Negroes take the 
best care of their bodies; if we converse with ministers, white or black, we soon discover that the educated Negroes are necessary to the religious racial evolution. The main evils which have afflicted the race have been bred in an atmosphere of illiteracy, ignorance, prejudice and superstition, and to these things the educated Negro is usually unalterably opposed. "The rudiments of an education for all, industrial training for many and a college course for the talented few" is the policy which will eventually drive away many spectres of racial discord. Some thoughtless persons decry the educated Negro, but he is really indispensable for peace, good order and progress. The educated Negro does not expect to break down racial distinctions; he only attacks racial discrimination. On all sides, the educated $\mathrm{Ne}-$ groes are saying, "We do not want to be white men, but we do want the justice and protection which are due us as human beings and American citizens."

According to the Directory of 1866 there were two African Baptist Churches, two African Episcopal Churches and one African Methodist Church in Richmond.20 By 1869 there were sixAfrican Baptist Churches, one African Methodist Church and one African Episcopal Church.21 In this latter year Rev. John Jasper is shown as pastor of the African Baptist situated on fourth and Canal Streets. At Norfolk, the Directory of 1867 shows two African Baptist Churches, one African Methodist Episcopal Church, one African Methodist Protestant Church and the St. James Methodist Episcopal Chapel.22 It will be noted that for the first two years after the war little progress was shown in organizing churches compared with what was to follow. The stir incidental to unsettled conditions, the trials of moneymaking, and the natural division of opinions at such a time caused building energies to be temporarily held in check. When these energies were released, churches sprang up all over the land and such churches were distinctively Negro churches. There are two periods of the church building and buying activities. The first period began within a reasonably short time after

20. Richmond Directory 1866, pp. 122, 123.

21. Ibid 1869, p. 26.

22. Norfolk City Business Directory. 
the war ended and is characterized by a desire to erect buildings. This yearning to build developed into something similar to a nervous frenzy. When these churches began to be built they sprang up like mushrooms. A trip through the principal cities of Virginia would have shown a transformation in the matter of temples of worship for Negroes that might have made the fable of Aladdin's Wonderful Lamp seem plausible. Religious zeal. pride, a desire to outdo each other, a desire to show the whites what they could do, are some of the factors which influenced these activities. A ministry to match the period existed. The preacher was a mighty builder and led his people to see visions of the projects ahead of them. He pleased the big audiences of emancipated blacks that rushed to the cities and was generally an adept at the game of church politics. Frequently his morals were not good, but he certainly did build churcles.

The second period was that of the payment of debts incurred in building the churches. These obligations were hanging over many buildings and the Negroes certainly did not want their property sold because of foreclosed mortgages. They made herculean efforts to pay for their churches and had great rejoicing when no more debts remained. The Negro churches of Virginia have surprisingly few debts now and always will have comparatively few long-standing debts so long as the race continues the great sacrifices which they now make. Judging by the silence maintained by some Negro writers concerning one phase of the Negro's church life, we might be led to believe that someone had urged that the thousands given by the whites of the South for Negro churches should be kept a profound secret. Money giving to their churches is one form of Christian activity in which the whites are anxiously urged by the blacks to take a part. No man can estimate just how much has been given to the Negroes to help them build. Many of the whites regard the church building cards which the Negroes hand one as nuisances, yet they pay toll amid the "Thank you, sir's," "Thank you's," and "God bless you's" of the recipient. The type of pastor for this period was a manager and a money getter. He knew business and generally was a calmer man than the builder type. He was usually a much greater man intellectually and morally.

From the very fact of their tremendous numbers we shall be 
unable to trace the individual histories of the Negro churches, but we shall endeavor to state some of the considerations that made the Negro do as he did and some of them that made the white man think his own way. It was inevitable that the Negro should wish to worship separately from the whites after the war, and as the natural consequence, a withdrawal from the white ecclesiastical organizations was in order. Purely Negro religious communions like the African Methodist Episcopal Church and the African Methodist Episcopal Zion and the African Baptists gathered to themselves the great hordes of blacks. The Negro was never more anxious for independence than he was in the matter of desiring a church existence absolutely free from white control, oversight, or influence. The reasons for desiring this independence are not difficult to discern. Soon after the cessation of hostilities and while the future was still in doubt the whites were very much alarmed on account of a threatened social upheaval. The National government by amendments to the Constitution, and by the act of March 2 . $186 \bar{z}$, was attempting to guarantee the Negro civil and political equality. The dread was always present in the South that civil and political equality were but stepping-stones to social equality. This dread affected the racial relationships to such an extent that the Negro did not feel as comfortabie in the white churches as he had felt formerly.

The Negroes who continued to worship in white churches were confined to certain pews or gallery benches after the War, just as they were before the first shot had been fired. This was repellent to the Negro because it seemed a confession of inferiority to sit in separate places, and further, those seats reminded them of the days of slavery. ${ }^{23}$ In this unsettled period, strenuous efforts were being made by some to forget that there had ever been such a thing as slavery, or social distinctions. The Union Leagues and the influence of some of the Negro leaders made it next to impossible for even a highly respected ante-bellum slave to retain his membership in a white congregation. The taunts of the women were especially disconcerting. We must remember, too, that the Negro is naturally gregarious and joined with the

28. P. A. Bruce, The Plantation Negro as a Freedman, p. 106. 
crowd. It required a discriminating courage to stand for theological tenets in the face of contumely and ostracism. A few brave ones, however, would not be intimidated, but the vast majority were mindful of the pressure brought to bear, and joined the strictly Negro churches, or the Northern branches of the white ecclesiastical organizations.

Bishop Atticus G. Haygood suggested another reason when he said: "Tongues and ears were made for each other; in each race both its tongues and its ears have characteristics of their own. No other tongue can speak to the Negro's ear like a Negro's tongue." 24 The white ministers made efforts to proclaim the message to the blacks so that it would do the greatest good, but a gulf seemed to have been fixed between the speaker and the hearers, and there was no opportunity for the perfect personal appeal. The Negro preacher, however imperfect, could speak to them out of their own experiences; his psychological development was more like theirs; his message could be easily interpreted by them; he rarely, if ever, rose above the level of their intelligence. Their own preachers were far more congenial to their tastes, and their theological ideas far more plausible to the blacks than anything the whites could offer them.

But the strongest reason of all, perhaps, for separate worship was the fact that religious exercises in the white churches were restrained and gave little opportunity for the "happy" worshippers to give vent to their feelings. Without some clapping of hands, stamping of feet, shaking of heads, shouting. falling out, etc.. the service would have seemed rather flat to the enthusiastic Negro believers of those days. In the big meeting times at the Negro churches when emotionalism was manifest at its worst, we are told that frequently the Negro women would stop falling out because no one would catch them, and if one did fall, the black exhorter, wildly excited and profusely perspiring, has been heard to send his commanding voice ringing through the house, filled almost to suffocation with emotional worshippers: "God drott'er, doan touch 'er. Let'er stay whar de Lord flung 'er." All of this seems crude enough to us at the present day in comparison with the quiet, well-behaved

24. Atticus G. Haygood, "Our Brother in Black" p. 222. 
Negro audiences which meet every Sunday in some of the more advanced churches of our Virginia cities. Yet we must remember that the time when most of this wild emotionalism was manifested was near the release from slavery and before the selfcontrol incident to education had been given an opportunity. It is only fair and just to say that such wildly emotional scenes are still very frequently enacted in the country churches, and we have been in attendance when such abandon was seen in city churches, not longer ago than the first part of 1914. It is certain that this desire to give unlimited vent to their feelings was a very prominent factor in leading to the ecclesiastical separation of the races.

Another reason for an ecclesiastical separation is to be found in the somewhat different conception of the uses of a church building. Many white churches are utilized for regular worship only. The Negroes utilized their churches for social centres, as well as for ordinary worship; and widely varied are the uses to which their churches are put. The Negro church was the natural meeting place of Negroes. Their training all through slavery had taught them that meetings elsewhere were forbidden. The preaching services, Sunday-schools, prayer meetings, Christian Endeavor Societies, Baptist Young People's Union and kindred societies such as Buds, Sunshine Circles, etc., make up only a small part of a week's program in an ordinary Negro church. The socials, festivals, debates, lectures, entertainments, oyster suppers, ice cream sales, stereopticon views and occasional political meetings still by no means exhaust the list of attractions housed in the Negro church, but merely suggest some of the possibilities. It has been said: "The social life of the Negro centres in his church-baptism, wedding and burial, gossip and courtship. friendship and intrigue-all lie in these walls. What wonder that this central club house tends to become more and more luxuriously furnished, costly in appointment and easy of access," ${ }^{25}$ and again, "The Negro Church of today is the social centre of Negro life in the United States, and the most characteristic expression of African character." 26 Booker Washing-

25. The Philadelphia Negro. W. E. B. Du Bois, p. 205.

26. The Souls of Black Folk, W. E. B. Du Bois, p. 193. 
ton said: "It is the core, the heart, the centre of organization in our social affairs and under the wing of the Church social life is apt to be more refined and wholesome than under any other auspices." $2 \pi$ There is reason now for the Negroes to give themselves pause concerning the over-development of the social features. The fundamental purpose of a church as a house of worship and a place for Christian instruction and fellowship is sometimes almost lost sight of in this social age and it is perhaps undeniable that among the Negroes, "the numerous church socials, the multitudinous societies, the prominence given to certain rites and ceremonies, fill the life of the average church member to a dangerous extent." 28 Of late, the better educated ministers are insisting that the churches be used for strictly religious purposes and committees of censorship pass on the attractions offered, and in one instance at least. which came within our knowledge. cut short an entertainment that did not live up to its advertising. It is needless to show further that this difference in the conception of the uses of a church building must have been one of the factors which. of necessity, led to a separation soon after the war. when the differences of opinion between the races were more pronounced than at present.

The accessions to these churches were very rapid. The preaching was of a type calculated to add numbers rather than to carry deep convictions. The church became a central bureau of information and matters were frequently discussed into the "wee sma" " hours of the morning. Very frequently politicians would ingratiate themselves with the Negro preacher and the Negro vote would be deflected at his will. In certain precincts so much money would be paid for so many votes and the preacher was forced to deliver them or lose his reward. The crime of voting with the former masters was considered so reprehensible as to cause some good old colored men to lose caste with their fellows and to endanger their church membership. How strong the influence of the preachers was before the Constitutional Convention of 1901-'02, is represented by some interesting facts concerning an election for State Senators from the city of Rich-

27. Missionary Review of the World. 27:835.

28. Negro Life in the South. W. D. Weatherford, p. 145. 
mond. Gen. Bradley T. Johnson and William E. Tanner, Esq.,

were Democratic candidates and no Republican candidates were named. Just before the election Messrs. Knight and Starke came out as independent candidates and were evidently dependent upon the Negro vote. Gen. Johnson had organized several strong "Johnson" clubs among the Negroes and had their vote pledged, but he was doomed to disappointment. On the Sunday night before the election every Negro pastor in town stated that the Negroes were expected to rote for Knight and Starke. and in the evidence turned in at a contested election inquiry, it was found that not a single Negro vote had been cast for the Democratic candidates. At one precinct where Johnson had eightyfive pledged voters, each one of them when examined as witnesses testified that his vote was cast for Knight and Starke. Johnson and Tanner won, however, without the Negro vote.29 Similar incidents could be enumerated but the influence of the Negro churches on the political situation is too well-known to need further elaboration. A very ingenious view-point concerning religion and politics was suggested by Lewis $\mathrm{H}$. Blair about 1889 who claimed that the South Carolina and Georgia Negroes had no desire to vote because they were so otherworldly or spiritualized as to think that Heaven was their home, hence they did not disturb themselves over conditions here: while the Virginia Negroes, under the influence of Mahone, had been urged to cast their ballots and take an active part in the world's present happenings. ${ }^{30}$

A later development has proved that in the event of very close elections, both sides in a bitter contest will bid for the Negro vote. It is not a secret that the votes of the Negroes are especially valued in "wet" and "dry" elections. ${ }^{31}$ We have been

20. See History of Virginia State Debt Controversy, Wm. L. Royall. pp. 38-'9.

30. The Prosperity of the South Dependent upon the Elevation of the Negro. Lewis H. Blair, p. 73 ff.

31. While in Slavery the Negroes were protected from the evils of intemperance by legislation and by their masters-except at Christmas. Temperance Committees brought in strong reports certainly as early as 1870 in the A. M. E. and Baptist Conventions. See African Methodism in Virginia, J. L. Butt, p. 43; Baptist Convention Minutes of 1871, p. 20. 
assured that one election which hinged on these votes was turned to the victorious side because prominent Negroes were not taken into pre-election caucuses held by leaders on the losing side. At Norfolk, in the November, 1913, elections, it was well known that the unprecedented switching of the Huntersville Negro vote from the machine, or "Ring." to the good government forces, or Citizens Party, was almost entirely ascribed to the influence of a very remarkable and prominent Negro preacher. Rev. C. S. Morris. ${ }^{32}$ Fortunately, the influence of ignorant Negro preachers in political situations where they could issue fiats and have them heedlessly obeyed was curtailed by the Constitutional Convention of 1901-02. but no check ever will be placed upon an intelligent, large-hearted Negro religious leader who wisely counsels the educated, best elements of his race. The Negro preacher is still a political leader but he is a saner. wiser leader than the men of the seventies and eighties because he is as a man usually saner and wiser and better than the man of that day. He is no longer entrusted with such unlimited privileges as formerly, but he is more honored by being a leader of the worthy men of his race who think and know, than he ever was, who blind himself, led voters blind and bigoted and ignorant.

The Negro Church is a highly complex organization. There are many societies in each. and the General Convention reports show not only the multiplicity of interests but the zeal in forwarding the same. The Minutes of every session of the General Conventions of the African Baptist Churches and the African Methodist Episcopal Churches, with the exception of the.first three of the Baptist Churches, are on my desk, and the excellent sentiments and high motives there exhibited would be a matter of pride to all Virginians were they well known. It is insane to doubt the ability of many of the men who were leading factors in these organizations. That many bad men were sometimes prominent, no one can doubt who reads these Minutes, but the general average of the intelligence of the leaders and their general worthy lives are causes of very favorable comment. Not only were missionaries paid by the Negroes to work in this State but others were paid who went to Africa. Temperance com-

32. The Norfolk Landmark and Virginian-Pilot. Nov. 5, 1913. 
mittees, Sunday-school committees, Home Mission and Foreign Mission committees and many others prove that the organizations were quite intricate. We shall enumerate only a few of the societies reported and taken into the membership of one of the State Conventions: Sisters of Charity, Young Sons of Liberty, Loving Sisters of IVorship, Zion Travellers, Phonix, Young Sisters of Love and Consolation, Sisters of Temperance, Daughters of Zion, Loving Daughters of Gethsemane, Sisters of Esther, Female Soldiers of the Cross, Female Star of Jacob, United Daughters of Ham, Loving Sisters of the Morning Star, Daughters of Useful Society, Young Rising Daughters of Golden Rule, Sons and Daughters of Moses, Rising Daughters of Jerusalem, Sisters of Canaan and Aged Sisters of Honor. All of these were religious benevolent societies and were very important factors in their Church. At this present day the fraternal organizations are rapidly coming to the fore. It behooves the benevolent religious societies to look carefully to their laurels. There is no doubt but that the competition for supremacy in controlling the social life of the Negro is becoming keener and keener because of the multiplication of worthy organizations outside of the church. The church is safe for the present but must build for the future to hold its young people. The bitter experiences of a few years ago when a prominent Negro fraternal organization became insolvent have sobered the Negroes on this subject. however. and they are now demanding better financial management and firmer moral security than formerly.

A Negro is a joiner of the first degree: he is "jining" something from his early days until his latest. This propensity could be turned to good account. No one doubts the value of the Negro under proper, strict discipline. The meritorious services rendered by Negro soldiers in various wars would forever disprove any aspersions cast upon their ability while under strict leadership. ${ }^{33}$ It will be the problem of today and tomorrow to provide the discipline that will hamess his religious emotionalism and get work done with the power that is now wasted.

There is one fundamental consideration which must precede every discussion of the Negro, and that is a recognition of the

38. The American Negro: His Past and Future. P. B. Barringer. 
fact that Negroes, like women as defined by the Irishman, are all alike in that all are different. An educated German of our acquaintance expressed surprise on his first trip to America that we were able to distinguish individuals of the Negro race. Even in the North we have heard learned men express surprise that the Negroes of Virginia should differ from the Negroes of Georgia or South Carolina or anywhere else. It would be impossible for a real observer to fail to recognize a difference in the personalities of individuals, and further, the aggregate difference in personalities of the individuals of one State as compared with those of another. These differences exist. Even the Negro recognizes them..$^{34}$ We have stated in a previous chapter the processes of selection which might account in part for many of the general excellencies of the Virginia Negro. Many, however, can see few or no excellencies in any Negroes. Dr. II. H. Ruffner, Superintendent of the Public School of Virginia for 1874, said: "The Southern Negroes are polite, amiable, quiet, orderly and religious: and hence it is hard to believe that as a class they are without character. And yet such is the unhappy fact. . . . And whilst families and congregations which have enjoyed special privileges exhibit better results, yet with the masses of those who claim to be Christians, their piety is of an unintelligent, sometimes superstitious, and always spasmodic type, and it covers a multitude of sins." 35 Dr. P. B. Barringer says: "A young savage by instinct, he naturally takes as his ideal the swaggering bully of his own color. He gradually, by theft and effort, gets up an equipment-no longer the bow, club and spear of his forefathers-but now a cheap pistol, a pair of 'knucks' and a razor. He goes to his first 'festerval' and the 'progress of the rake' is henceforth fast. Some night

34. Richmond Times-Dispatch, Aug. 28, 1904: "The chief theme of discussion yesterday by the colored Sunday-School workers of the Virginia Baptist State Convention (Negro) in session here, was class distinction among their own race. Rev. Paul Pollard of Richmond read a paper on 'Caste in Our Own Churches.' The subject was discussed at length, the gist being that a class line should be drawn between those colored people who had raised themselves above the ordinary level and those who still remained on the same low plain."

35. Christianity, Islam and the Negro Race, E. W. Blyden, p. 40. 
at a carousal he uses his ever handy weapon and flees, carrying with him everything of his parents' that he can steal. . . . By the time he is even fully grown, he is far from home and has almost forgotten the parents that gave him birth: he is a liar. a thief and a rake: a gambler and perhaps a murderer or highwayman. He fears neither God nor man, and when an opportunity offers is ready for any crime. He is in his own vernacular 'a bad man,' and for once he does not lie." si One quotation from a Negro writer. $\mathrm{Wm}$. Hannibal Thomas, is now presented: "From my youth I have had an intimate knowledge of negro religionists, and have learned to know from personal experience the shallowness of their pretensions. the depravity of their morals, the ignorance of their ministers, the bigotry of their leaders, and the levity of their faith. . . . . I have found the unlearned bigoted. the learned of the race pompous: and all of every sort, pitifully inclifferent to the welfare and uplifting of men and women sitting in darkness and the shadow of death." Every one of these opinions is true concerning a certain class of the Negro populace, but just there is where we do the better elements of the Negro race an injustice. Dr. Ruffner did differentiate somewhat. It is absurd to talk about Anglo-Saxons being scientific if we cannot distinguish between the doings of criminals, slum Negroes and the worthy lives lived by many a wellbehaved, aspiring, educated Negro.

We watched the Negro workmen at the end of a day's work leaving the great Newport News Ship Building and Dry Dock plant: we stood on the wharves at Norfolk and saw the longshoremen at their daily tasks: we heard the ringing notes of the tobacco Negroes in the great factories at our State capital; we have talked to the Negro tilling the soil of this Commonwealth, and in,every instance there was a difference. The differences were not so great between those at the different tasks as the differences between those at the same tasks. There is great hope for some: for others, the words of an untutored. burly, Irish machinist at Newport News are, unfortunately peril-

36. The American Negro: His Past and Future, P. B. Barringer, p. 18 .

37. The American Negro. Wm. Hannibal Thomas, Preface, p. 21. 
ously near true: "An ignorant, illiterate Negro ain't worth a d-n nowhere." He did at least differentiate. There is little wonder that the Negro is driven almost to desperation by the vicious attacks made upon the race, which were really intended to be aimed at the lowest elements in their race. The better Negroes are willing to agree that the faults of their weaker brothers can hardly be condoned, but the sad fact remains that we sometimes by our carelessness indiscriminately weaken the hands of those same worthy ones who are laboring under the burden of racial woes. Differentiation must be used: else we should refrain from calumny. The only generalization that is at all fair to make concerning Negroes as a race, is the generalization that we should not, without qualification, generalize. It would seem that in the presence of so many types of Negroes no person could fail to divide the Negroes as a race into fewer classes than five:

In the City.

(1) The law-abiding, educated, aspiring Negro.

(2) The slum Negro with surroundings that fit him for crime.

In the Country.

(3) The industrious, quiet, hard-working farmer and land owner.

(4) The thriftless "hand," without ambition.

In Coal Mines. Saw Mills. Railroad Camps, etc.

(5) The public works laborer with few religious advantages.3s

As the Anglo-Saxon love of fair play is brought more prominently to our attention, we shall exercise an ever-increasing care that at least no innocent men shall suffer in the place of the guilty.

One of the most momentous occurrences in the life of a Negro church is a split. Fortunate indeed is that church which has not suffered in this manner. In the first instance, money matters are frequently the root of this evil. Careless accounting leads part of the congregation to think that money has been misappropriated (frequently it has been) and the congregation is rent

38. The Southern Workman. July, 190\%, p. 390. Also "The First Century of the First Baptist Church," p. 26+ ff. 
in twain. It is regrettable that preachers have so often been guilty of such peculations. Another occasion for a split in a Negro church is the immorality of the shepherd of the flock. In spite of the most convincing testimony, part of the congregation will sometimes blindly cling to their pastor and refuse to force his resignation. The more moral elements among the Negroes, thoroughly disgusted, leave the old congregation and set up a new house of worship. frequently in a community where one well-conducted church would have been sufficient for all the religious needs of such a community. Another reason for splits in the churches is to be found in the personal magnetism of certain individuals. A young man is told by some of the brothers and sisters that he can "put up" a better prayer than the regular pastor, or can preach a much better sermon. He chafes because his talents are not more quickly recognized and with a small following sets up his tabernacle at a little distance removed from the former church and begins his work. At other times an illequipped preacher will "refuse to accept his resignation when it is offered to him" and the more educated members will cut the Gordian knot by setting up a new work and calling a new preacher better suited to their attainments. The words "old site" and "new site" generally have behind them a history of difficulties in the churches which eventually let to splits. Even the great Virginia Baptist State Convention (Negro), several years ago, split into two parts that are now commonly referred to as the Association and the Convention. It is a matter of encouragement to believe that this breach which seems to have been caused by personal ambition and a lack of coöperation, will soon be closed and harmony once more prevail among the Negro Baptists of Virginia. It is evident that independent churches with congregational forms of government are far more susceptible to such breaches than are the churches under the authority of the bishops or other ecclesiastical officers.

An interesting remnant of slavery was preserved in the Negro's disregard of property holding as being' opposed to their religion. During slavery the blacks were not encouraged in many instances to hold property, and in some instances they were positively discouraged. The masters had endeavored to supply all the needful wants of the slaves. The Negro's religion was of 
such a nature that his yearnings were far beyond the skies, and since they did not have wealth it became very easy to think that those who did were endangering their chances for Heaven. In a very instructive investigation conducted by C. B. Dyke in some of the Tidewater cities and rural districts. he found that the attitude of the great majority of Negro children could be expressed, "God don't leck (like) rick folks." 39 All of this sentiment, however, is rapilly dying out under the teachings of Hampton, Tuskeegee, and other prominent institutions. Booker Washington's great quadrivium, "property, economy, education and Christian character" expresses the latest tendencies of Negro thought. Many believe that he should have placed Christian character first instead of last. His program and his books present economics as the chief means to the end. Religious reform, it would seem, is to be effected after economic stability has furnished a racial foundation. It is to be sincerely hoped that in these rushing times "the most influential organization among Negroes," the Negro Church, will carefully watch its wards and make impossible a subordination of character to economic prosperity.

No one can doubt the prominent place of finances in Negro church life. The Negro not only loves the Church with his heart but with his pocket-book. In the past no sacrifice was too great, nay, not even virtue itself, if it was undergone for the church. Rallies and special collections are never ceasing. To "lift a collection" well is considered quite an attainment. In the matter of church buildings the Negroes equal, if they do not surpass, the whites. Whereas some of the more expensive white churches in the city have no counterparts among the blacks, still the average Negro church in the country has a good building and is as well if not better fitted for services than the average white church situated in the country. To have accumulated millions of dollars worth of property and spent thousands in salaries and missionary enterprises, required a spirit of generosity rarely, if ever, equalled by any people in the same financial conditions. This prominence of money in the life of the church is well exhibited

39. Popular Science Monthly, C. B. Dyke. 60:360-364. 
in a statement of the functions of the Negro church as interpreted by Du Bois. He arranges them as follows:

"1. The raising of the annual budget.

"2. The maintenance of membership.

$\because 3$. Social intercourse and amusements.

" 7 . The setting of moral standards.

*5. Promotion of general intelligence.

"6. Efforts for social betterment." 4 "

There is much to deprecate concerning the lives of so-called religious Negroes. Would that profession and performance could be brought nearer together. From the very first of this study nearly every man's comment on their religious pretensions have re-echoed the word "shallowness" like a constantly recurring refrain. It has been the fortune, or misfortune, of some people successfully to assume the virtue of godliness even if they had it not. but the Negro is rarely allowed to begin an assumption. The whites do that by postulating something very close to hypocrisy as a necessary condition of every religious Negro $\mathrm{s}$ life. That such a hypothesis is radically wrong is too evident to need statement. yet we tolerate these wrongs. Much of the Negro's religious life is spent in feeling, and far too little in doing. Many of them completely exhaust their religion in feeling. The ethical aspect of religion is only known to the upper tenth at present. Long. repetitious prayers, shoutings, 'zortations, church attendance and payment of dues. mark the extent of the influence of religion in the lives of a great many. His spirit is very devout "so far as this signifies a passionate religious feeling in contradistinction to sober and godly conduct : as an abstract hope and naked aspiration. it colors his whole nature as much as his most impetuous appetites do."

The divorcement of religion and morals is a most unfortunate condition which prevails far too extensively. Frequently sins are committed during, or immediately after, a religious service. An old Negro who testified in meeting that he had cursed some, had stolen some, had drunk whiskey some, and had done other things some, but could thank God that he had never lost his religion, is fairly characteristic of an attitude towards the rela-

40. The Philadelphia Negro. W. E. B. Du Bois, p. 202. 
tionship between religion and morals held by some of the lowest and most depraved. An incident of particular interest is noted by Olmsted which shows the Negro's implicit trust in the Bible and further demonstrates that the Negro can at least cite Scripture for his purposes. A white minister was endeavoring to correct a slave for wrong-doing when the following dialogue ensued: "Look yeah, massa. don't de Scripture say dem who b'lieves an' is baptize' shall be saved?"

"Certainly." was the reply. and the clergyman went on to explain the passage to him. but the slave interrupted him again:

"Jus" you tell me now, massa, don't de good book say dese words: 'Dem as bives and is baptize' shall be saved"?"

"Yes but-"

"Dat's all I want to know, sar, now wat's de use of talkin' to me. You ain't ago'n to make me b'lieve what de blessed Lord say aint so, not if you tries forever."

The lack of exalted practical ideas and worthy, inspiring ideals leaves the religion of the Negro woefully weak. Too often the popularity-loving pastor preaches down to his congregation. A young minister with excellent training and a fervent spirit starts out to proclaim the word in a manner in keeping with his education but soon finds his efforts are unappreciated by his congregation because they prefer "whang-doodle" and "rousements" to cold religious logic and ethical teaching concerning sins. A very direct application of the Scriptures to prevalent conditions will almost certainly throw a damper over the meeting. Such conditions have come within our knowledge and are particularly discouraging to those interested in the racial uplift. A white man who is considered religious would in ninety-nine cases out of a hundred bear at least an excellent moral character, but to say that a Negro is religious means nothing without knowledge of the individual. In other words he "needs to be taught that more of the religion that manifests itself in his happiness in prayermeeting should be made practical in the performance of his daily tasks." The breach between profession and performance is really at the bottom of most of the Negro's religious problerns. It is a pity that it is so. A people who are intensely, instinctively religious as are the Negroes. stand in some danger of disgusting the educated minority of their race with things religious because 
of the prevalence of shadow rather than substance, of profession rather than performance. of emotional extemals rather than intelligent ethics. And this educated minority is an all important factor among Negroes since it furnishes the leaders to guicle their less fortunate brothers out of the wilderness. None of the-brainiest Negroes claim that superstition has no hold on their race. They merely claim that it has no hold on the more educated part of the race, and they further maintain that it grips the rest of the race now with much less force than formerly. It is not to be expected that superstition would relinquish its hold very easily. It was firmly entrenched in the Negro's habits of thinking and a change in thought-life is part of a long process. Of course. it is an insult to the very principles of the Christian religion to be a Christian and at the same time be a believer in superstition. White men and black are both guilty of this, however. We whites dodge about too frequently like cowards, rather than begin an enterprise on Friday or have anything to do with the number thirteen. Have we rid ourselves of superstition yet? The Negro. carries his rabbit's foot, crosses his fingers, steps with his right foot first over the door sill, believes in ghosts, hoodoo"s, "conjurs" others and is "conjured," etc., until it seems that he forgets that he is a Christian in a Christian land. The mere fact that "conjur" doctors live quite prosperously in several sections of our State would indicate that their business is still popular. In Louisa County a Negro was employed to fire a saw-mill engine. and in spite of his best efforts something went wrong with the boiler. He urged his employer to lend him $\$ 3.00$ to go to Spottsylvania County and get a "conjur" doctor to give him professional advice as to the trouble. The doctor assured him that the engine was certain'y tricked and nothing could be done until the boiler was thoroughly cleaned out and a mysterious powder inserted before fresh water was poured in. Naturally the mill ran well at first, after the boiler was carefully cleaned, and great was the joy of the fireman, but his elation was very short-lived, since the mineral deposits in the water caused the sane complications as formerly. Of course the Negro did not lose faith in the doctor. He blamed other things. Experience does not teach everybody. These happenings were not events of 1713 or 1813 , but 
occurred in the early part of the Twentieth Century-in the year 1913.

The superstitions connected with inanimate things, however, are not nearly so important as those connected with animate. The former are more numerous; the latter more consequential. It is a frightful tragedy for one Negro to trick another.t1 The white man can hardly comprehend it. The manifestations are so distressing that the afflicted one is the object of universal pity, and medical science is baffled to minister to minds diseased. The lizard is very frequently thought to be connected with a person tricked and is supposed to be living on the unfortunates vitals. Old Dr. Buckner, a preacher and physician of some years ago, had a "conjured" Negro patient and he undoubtedly saved her life by using his hard common sense. It must be remembered that Negroes really die from sheer weakness after being tricked unless the evil force is removed or a counter spell can be wrought. After finding a lizard the good doctor put it in a box and concealed it on his person. He commanded that a wash-tub be halffilled with water and placed in front of the patient who was given a strong emetic. When the vomiting began, the doctor told her to look for a lizard and when she was sickest he dropped the lizard into the tub. The sequel found his patient speedily convalescent. As valuable as human life is, it is a very sad thought to think that no inconsiderable number of lives are sacrificed every year because of such base superstitions. It is high time that education should drive out this type of mental darkness.

When the Negro was first brought to America he was so steeped in superstition, and the process of teaching his simple mind was so difficult that it is not surprising to know that he clung to superstitions even while grasping after spiritual ideas. The constant efforts of missionaries and good masters. at last, proved efficacious in making some few Christian ideals and ideas clear. It was a Christian veneer, at least. After being in America nearly three hundred years the Negro is now thoroughly Christian in most particulars but still retains some of the heathenish ideas adapted to the new religion.2 With such a religious

41. The Plantation Negro as a Freedman, P. A. Bruce, pp. 111125.

12. The Negro Church. p. 5. 
history and such a racial history the great majority of Negroes could not well be otherwise than spasmodic and emotional in their religious lives.

$>$ It was not always a simple matter for the would-be convert to gain admission into the church. Experiences were very important factors and these were weighed very carefully before the candidate was encouraged to think that he could enter the Ark of Salvation. These experiences were supposed to be soul travels and travails. A peep at old Satan was almost indispensable as a proof of genuine experience, and fortunate indeed were those who heard "sweet moanin's" or were "shuck" over Hell. To the present day these conditions prevail in some localities. Those who are having these soul trials are called "seekers." The "seeker" usually takes on a pitiful look, practically stops work. and "mopes about." Great interest is manifested in the "seekers" as they are the possible church members. There is rejoicing in the land when the "seeker" has "come through." His experiences are recounted with the greatest interest and all give strict attention to such a narrative. Whether they found their Jesus in the church, in the home, or as a little Negro of our acquaintance said. in the hen-house, makes no difference. The great item is whether they found him or not.

Have you seen a Negro baptizing in the country? It is often a spectacle. The procession from the church to the picturesque mill-pond at baptizing times is well known. The whole congregation marches two abreast and often the candidates wear white caps. Sometimes a few are hard to manage in the water and frequently after immersion some will loudly proclaim that they saw their Jesus. In the cities, pools are in many of the churches and the baptizing takes place indoors. Usually the indoor ceremony is orderly and quiet and reflects great credit upon all the participants.

It has never come within the experience of any of the many persons whom we have conversed with concerning the religious practices of Negroes, that a Negro was ever known to be so busy that he was not able to stop work long enough to shake hands with a new convert, and speak some words of encouragement. When the new convert has "got religion" he often goes about rocking his body and chanting these or similar words: 
"I am redeemed. I am redeemed. And washed in Jesus blood. I took my feet out of the miry clay and set them on the Rock of Ages where the wind may blow and the storm may rise and the very gates of Hell will not prevail, thank God." The handshake is inevitable. The Negro delights in it. No color line is drawn there: the white man, of slavery days especially, shook hands with the black man and hoped that he would live a nobler life. The black man believed at the time that he would, and we are convinced that all would have gone well if the emotional excitant could have been kept ever operative, but alas, we face facts, and not theories. The emotionalism which was sustaining for a season, no longer stinulated and many believe that "the last state of that man is worse than the first." F. G. Ruffin said: "With exceptions, negroes are worse in character after they 'profess conversion' than they were before. It is dreadful to think that Christianity, which has not only redeemed but civilized all the nations of the earth that can claim to be civilized in any high sense, should be an injury to the negro: that that 'Light which lighteth every man that cometh into the world" should be an ignis fatuus to him." 43 Such a radical view as that taken by Ruffin is certainly not representative of the facts in the case. The Negro does do wrong after conversion (as every one else does). but he is a malefactor not because of his religion, but in spite of it. He knows better in almost every instance. but the flesh is weak and the temptations strong. Some of the more ignorant may consider their proiession of religion a mere insurance policy to keep them out of Hell. but most Negroes now think far differently. The triumphs of the faith in changing the bad lives of many Negroes into better, are not among the least consequential victories won by Christianity.

Can we expect a bitter spring to give forth sweet waters? "Do men gather grapes of thoms, or figs of thistles?" Neither need we expect the Negro race to make any rapid moral advances until their domstic life has been improved. One of the most unfortunate influences of slavery was the failure to per-

43. The Negro as a Political and Social Factor, Frank G. Ruffin, p. 22 . 
mit a full realization of the meaning of the family circle. Many of the best masters and mistresses were particular that families should be kept together and these were taught the principles of family life, but many others paid little attention to such things. As a rule the domestic virtues were undeveloped among the Negroes, and as long as these conditions existed or do exist the efforts to cut down the excessive immorality will prove abortive. It is very noticable that the slaves from the "quarters" are usually morally inferior to those raised in the "great house." The Negro is imitative and the house servants could see high family relationships and could profit thereby; the Negroes at the "quarters" experimented among themselves. The Negro masses have not yet learned the importance of the family as an institution, but they are rapidly being taught these lessons of higher life by their intelligent leaders. The painstaking observer will not fail to record that there are many new names added each year to the list of those who have a true conception of home life: and these additions are important in developing the family life, since it is recognized that "the only adequate measure of social efficiency and the only ultimate test of essential race progress lies in the capacity to create the home." 4 Few whites know anything about these advances. The newspapers, the police court records, the tales of the idle devote much space and time to flaunting the criminal side of this race before the world, and rarely a word is found of encouragement or recognition of those struggling, worthy characters-home builders-who are doing their best to promote family ideals. It became our duty in writing this monograph to visit many homes of Negroes, and it was a revelation to know how neat and orderly were the appointments; how well-kept were the surroundings; how well-chosen were the books in the libraries - of the better classes. The homes of the slum Negroes show a corresponding want of elevating factors. Of this latter class the summary of the characteristics of the Negro homes in America, as found in an Atlanta University Bulletin, 45 is frequently-not always-true without

44. The Present South, E. G. Murphy, pp. 166-168.

45. The Negro American Family, p. 48. 
qualifications: "(1) Lack of comfort: (2) Lack of hygienic customs: (3) Lack of thrift economy: (4) Lack of a father: (5) Absence of a mother." Crowded rooms. poor furniture. unsanitary arrangements, uncleanliness, renting, sub-letting, spending recklessly, surfeiting today and starving tomorrow, sexual promiscuity, illegitimacy. harsh treatment, undue punishments, services of mother tired out at night, and a consequent lack of maternal influence. make up an array of obstacles which would be-destructive of any white home, much less the home of the blacks. It is distressing, too, to know that often the white vice districts are located in the heart of the Negro residential sections. In Norfolk a block of twelve such white houses are found in the same square in which fifty Negro homes are situated. Occasionally lilies grow out of dung heaps, but not often. The only thing that saves this people is their optimism, and their failure to comprehend their misfortunes. We ourselves cannot realize their condition; if they did, there would be more suicides. These low class homes must drag down the average until the better Negroes and the better whites combine their energies to solve the problem, for as Bishop Haygood has said: "Without true religion the pure home life is as impossible to the Negro as it is to the white man; without pure home life Christian civilization is inconceivable." And most of this problem of home life rests with the warm-blooded women of the race. The white man of slavery days too frequently plunged himself and his female slaves into an abyss of shame, but a change has come since Reconstruction. ${ }^{46}$ No self-respecting white man dare commit such a crime now without losing caste with his fellows. The Negro race has its chance to develop womanhood capable of conserving racial progress. Without such pure women the task of elevating the race is hopeless.

We are looking through a window in our University room. A row of plain brown houses can be seen built on the side of a hill. There appears to be no more difference in their style of architecture than one sees in the tombstones that mark the graves of privates buried in a U. S. National Cemetery. The

46. The Plantation Negro as a Freedman, P. A. Bruce, pp. 53-55. 
street is muddy, no trees are near, and all things conspire to give one a feeling that those houses represent temporary habitations and not the permanency of homes. The idea of transiency is especially abhorrent to home builders. Of course, the house and surroundings do not make a home. yet they help. Pride in the upkeep of their dwellings can be inculcated in the Negro race only as they are urged to own property and are taught that every cent paid in beautifying the environs enhances the value of their own possession. It must be said to the shame of the white race that too frequently fortunes have been amassed by our business men who erected cheap. unattractive, uncomfortable houses to rent to Negroes, which yield a big percentage on the investment, yet rob the blacks of a fair start in life for their children. Albums of photographs could be presented to prove the unattractiveness of such places. but the mention of one will suffice. After leaving Alexandria. Va., and when nearing Washington, D. C., there is a brick kiln on the left side of the Southern Railway tracks, not far from the. kiln are stables, and not far from the stables are houses. One look at these miserable houses and their back yards will give more light upon the moral destitution of a certain class of $\mathrm{Ne}$ groes than tons of print. It may be possible for men and women to be very godly in such surroundings, but if they can be so there, in a better environment they could be angelic. Heredity is powerful, but environment is, too. Both are too frequently against the Negro child's chances for a successful moral life.

Closely connected with this problem of the cultivation of home instincts is the question of furnishing proper amüsements for Negroes. The age of monasticism has gone, and dying embers of a blue-dyed Puritanism lie smouldering on the hearth, giving forth smoke but no warmth or light. The amusements of Negroes must be interpreted in a broad-minded way, or the Negro Church will face either the problem of driving the young from its doors, or that of sheltering hypocrites. Neither alternative will be necessary, if intelligent leaders will step to the fore and guide the Negroes in this important crisis. Kindergarten teachers tell us that playing does not come natural to 
all children: some have to be taught how to play. Ignorance concerning this matter is naturally greatest among the Negroes, and to this race of greatest need efforts have recently been directed. In Louisville, Ky., Rev. John Little has been conducting a playground for Negroes with great success, and in our own State, Mr. W. M. Gray, of the Union Theological Seminary, has been conducting a very successful one in Richmond. Lessons of cleanliness. hopefulness and strength can be inculcated here when they would not be tolerated elsewhere. Athletics is practically a new word in a Negro's vocabulary and the sooner it becomes a fixture the better for the race. Heretofore we have assumed that a Negro child could get its exercise by working or by running from the "cops." At the present, we are improving their morals by means of an interest in athletics. It is the common experience of those who conduct such playgrounds that morals are vastly improved by them and many of the children who come to play, in later years remain to pray.

As long as some of the Negro churches failed to recognize the difference between dancing and theft, worldliness and unchastity, and others considered dancing worse than lying and playing the fiddle worse than adultery, the whole question of amusements remained very acute. The same penalties have been known to be inflicted for each of the "sins" enumerated above. Theater attendance is also blacklisted, and too frequently those guilty of lying or rum-drinking sit in council to try the offenders. Dance halls, cheap vaudeville, pool-rooms, eating houses and groggeries, with an occasional merry-go-round or "movie." make up the biggest part of the list of amusements of the Negroes. In some of the smaller towns not eren one single amusement device or playground for Negroes is to be found, and the streets or churches have to endeavor to supply this craving for fun. Real games are a necessity, especially for the young of the slums, and in lieu of diversions, the sins which are the accompaniments of idleness arise to destroy. In one of the Tidewater cities of Virginia, the colored Y. M. C. A. secretary found many of the boys practicing secret vice simply because they had nothing to do and no one had told them bet- 
ter. The Y. M. C. A. with its baths, play-rooms, athletic contests, and study classes, is doing much to fill a long felt void in the lives of the Negro youths of Virginia, but a multiplication of all these forces which make for better amusements is now imperative. What will we do about it? At least, we realize our duties better when we recognize the fact that wholesome sport is the inveterate foe of sin.

In the facts which we have presented above, there seems much that would incline the pessimist to be convinced that no good is in the Negro and hence no good can come out of him. The crimes which they commit, the shallowness of the lives of so many, the divorcement of religion and morals, the emotionalism, their self-sufficiency, and many other things, would incline us naturally to that belief but for the presence of many matters of hope. Among these factors the prevalence of optimism is perhaps the most important. The Negro race has convinced itself, at least, that there is good in it and along that line its conduct is now shaped. No man can say what the attainments of the race may be if this optimistic spirit continues. Virginia Negroes are much blessed in their leaders. The officers of the Negro Organization Society are able people and the inspiration which this clearing house of Negro progress sends out is met with enthusiasm by those to whom it is sent. Members of the race are constantly repeating: "We are rising." Without optimism they could do little.

Another matter of hope is the reverent attitude assumed by practically all Negroes toward the church. The Negro is not a scoffer. He may be very mistaken in his religious ideals, yet he is very true in his faithfulness to the church. The percentage of Negroes who take some part in their worship should cause some of the white race to hide their heads in shame. Even if the Negro has only one talent, he generously uses that one to the best advantage that he can. With nearly fifty per cent of the Negroes of Virginia members or communicants of churches, and with a large percentage of the others attending church services with some degree of regularity, there is a splendid opportunity for strong leaders to get hold of the people and institute reforms. 
Still another matter of hope is the diffusion of education among Negroes."i Their schools are meeting admirably the problems presented and are only handicapped by a lack of means. The educated Negro minister, teacher, and business man are rapidly coming to the forefront and are giving the race the leadership which it so badly needed soon after emancipation. An educated Negro who prejudices his brothers against the white citizens of this State is rare now and will probably become even more rare in future. Ignorance was the cause of many mistakes made by the Negro; education will be his salvation. Not only are better leaders at the head of the race, but better men are following. The old men are betterspirited than formeriy, and even that emotionalism which is now held up to the Negro as a matter of derision. is fast waning. The educated minister of today is generally a man of high morals and his impress. is not lost on the masses.

As a last matter of hope (there are many others which might be stated), we mention the interest which the people of New Virginia are manifesting in the Negro. The man who says that the whites look out for themselves, and should therefore let the Negroes look out for their own interests, merely confesses by his attitude how far he is behind the times. We cannot still be Christians and afford to let the Negroes go to the bad even if they want to do it. Our knowledge should be their strength and their weakness our opportunity. If we are strong spiritually, then we should play the Good Samaritan to this unfortunate race. To assume a "Holier than Thou" attitude would be to stifle ourselves by our own hypocrisy. We could hardly live, and certainly could not develop, in such an atmosphere. The chance to convert Africa in America is here "s and we shall not withhold our wisdom and guidance. Dr. P. B. Barringer was in entire accord with the truest religious views when he wrote: "We took the cannibal and made a man of him, and we did it because our grandfathers and

47. The Negro Church, p. 62.

48. The White Man's Burden, B. F. Riley, p. 149. 
grandmothers were not ashamed to give themselves to his guidance. There are in the South today the same people, and in this day of national peril. for it is national. as hard as it will be at first. they will not be found wanting." 40

In 1696 the Virginia Burgesses complained of the difficulties incurred in teaching the Negroes newly imported, and at present. unless the whites disseminate things helpful in an ungrudging manner, we may eventually have to face cases of reversion to original type. Since slavery days the time has never been so ripe as the present for the Negro and the white man to do constructive work. Dr. Jas. Dillard, Director of the John F. Slater and the Jeannes funds for the Christian education of Negroes, has his headquarters in this State and is a living incentive to other able men to give thought and time to this element of our composite civilization. The existence of clubs among white college students to study the Negro problem, further proves that the college men of New Virginia will have something more than hearsay evidence to guide them in passing judgment upon the merits and demerits of the Negro race. That the religious development of the Negro is a responsibility which demands the most earnest and careful attention no one will now deny. Mr. D. Hiden Ramsey has said: "It would be impossible to say that we shall do nothing for the Negro because the results are not immediate. In our program for the Negro we must look for our results to the future. Patience, slow time, sympathy, and discernmentthese must be trusted." so

The Negro judges the white man very frequently by the ruffians who attack him, or by the newspapers that libel his race; the white man too frequently judges the Negro only by the inferior quality of work done by servants. Most cases of dislike that we have investigated showed an economic basis. The fact that our cook suddenly leaves, or a farm hand de-

49. The American Negro, His Past and Future. P. B. Barringer, p. 14.

50. Lecture under auspices of Phelps-Stokes Foundation for the study of Race Conditions in the South at University, Va.. Jan. 31, 1914. 
mands higher wages or even refuses to work, impels us to exclaim, "How we hate a Nigger." Does not this position seem a bit unjust? Our attitude toward this race is too important to be dealt with in anything but a large, fair-minded way. Because a race lives on its own properties and no longer serves us in the same capacities as formerly are no just reasons for assuming an attitude of hostility to every phase of that race's existence. However, this very principle of dislike is at the root of much of the condemnation of the modern Negro. 
$1865-1913$.

\section{(Continued.)}

In the state of Virginia there are a score or more religious bodies to which the Negroes pay allegience. However, of the 307,374 Negro church members in Virginia the Baptist church contained about 270,219 , or 88 per cent of all Negro communicants, according to the census of 1906. ${ }^{1}$ The Methodist bodies followed with about 30,492 members or about 10 per cent of the total. and the remaining bodies follow with a few more than 6,000 , or about 2 per cent of the total Negro membership. In reality the great Negro faith of this State is Baptist and its nearest competitor is some form of Methodism. The combined value of the buildings in which these Virginia Negro worshippers gather was reported to be $\$ 3,562,930$ in 1906 with a little over $\$ 300,000 \mathrm{debt}$, and the total value of such property has undoubtedly increased very much since that time. Between the census of 1890 and the religious census of 1906 the Negroes gained about 70,000 in the number of their members and nearly doubled the value of their church property.? Advances have been made and are being made so rapidly that books can hardly be issued from the press fast enough to record the constantly changing phases of this portion of the Negro's life. When the Decennial Religious Bodies Census of 1916 is taken, and its contents made known, the part played by Virginia Negroes in the religious life of the race will be no unworthy one.

The first eleven ecclesiastical bodies in Virginia in the order of their Negro members' numerical standing. in 1906 were: Baptist, Methodist Episcopal, African Methodist Episcopal, African Methodist Episcopal Zion, Reformed Zion Union Apostolic (Colored), Presbyterian Church in the United States of America, Protestant Episcopal, Colored Primitive Baptists

1. Linited States Census. Religious Bodies 1906, Part I, p. 562.

2. Statistics of Churches. Eleventh Census 1890, p. 49. 
in America, Colored Methodist Episcopal Church, Christians (Christian Connection), Disciples of Christ: There are other bodies that are doing excellent work, but they have made no great advances in the church life of Negroes. The doctrine and policy of the Negro churches correspond very closely to those of the white churches. It is indeed difficult to understand why some of the churches maintain an independent existence when they might do better work united. For instance, W. L. Fleming says that the main difference between the A. M. E. and the A. M. E. Zion Church according to a Negro member of the latter was that in one the dues are twenty-five cents a week and in the other twenty. ${ }^{3}$ The larger Negro eccesiastical organizations have their own Church papers, official organs, and these are read extensively. In the Presbyterian and Episcopal churches the Negro ministry is especially well prepared. and also in the Methodist churches the influence of their respective Bishops generally has a tendency to keep the men on their mettle, but the educational results yet attained by the strictly Negro churches have not been so great as in the churches under white supervision. Indeed the phenomena seen in some of the Baptist churches are practically without anything like counterparts in the Presbyterian or Episcopal churches. The church strongest in numbers ministers primarily to the masses, although it certainly numbers in its membership some of the finest of our Negroes, while some of the smaller churches do effective work almost entirely for the higher classes. The classes claim that there is too much emotionalism in the Baptist and Methodist Churches; the masses claim that there is no "feelin'" and too many "gittin' up's and down's" in the Episcopal church. Each Negro church should have its hands full, and no one church has time for jealousy or bickerings while there is so much work to do.

Unless otherwise specified we shall write of the popular Baptist churches since some of the others exhibit few or no phenomena which would be striking. In many churches among the Negroes we have worshipped in audiences as calm and orderly,

3. Civil War and Reconstruction in Alabama, W. L. Fleming. p. 649. 
and outwardly at least, as unemotional as the average church among the white people. We shall not dwell upon this higher type of church longer than to express the wish that others would go and do likewise.

The church buildings in which the Negroes worship are usually far more excellent structures than one not acquainted with their liberality would imagine that they could erect. Few of them fail to have solid benches within, stained glass windows, a good pulpit and pulpit furniture, an organ, and book-cases or chests for Sunday-School supplies, etc. Frequently the same Negroes who live in squalid hovels worship in their own church palaces. Their ambition too frequently has been to build fine churches rather than good characters. A desire for a showy house of worship and a big attendance have been factors which lured the Negro preachers and church members to make sacrifices heretofore unheard of in America. Scriptural names are generally given to their churches, but this rule by no means always holds true. In the cities the larger churches are generally in the heart of the black belts with occasional missions or smaller churches on the outskirts. In the country, an effort is made to have the newly built churches near most of their members, but the power of some "big" member occasionally influences the location of the site at some distance from such a true center. Most Negro churches have a great bell to call worshippers to the building, and most churches are kept scrupulously neat and clean. Even though their furnishings are often showy and cheap, they are generally the best that the members can afford at the particular time; a later visit would probably show an improvement. Old fogyism is bitterly attacked; the effort is to keep up to date.

Sunday is a busy day with the Negroes. In the morning Sunday-school is in session first, then the morning preaching service. A few of the Sunday-schools are doing good work, but they are not well attended by the older people and their superintendents and teachers need the supervision of specialists. The tremendous advance in Bible school work manifested by the whites has not yet found a similar enthusiasm among the blacks. Some of the more progressive churches, however, have adopted these new ideas of conducting Sunday-school 
work and eventually all will catch up with the procession. After the Sunday-school session the regular morning preaching service begins. There is rarely any hurry about beginning promptly. The Negro gets enough of promptness and push during the week from his white employers. Leisurely the service begins and more leisurely it ends. The afternoon is generally free for visiting or resting, but occasionally society meetings make demands even on this brief time. Before the evening service. the B. Y. P. U.'s, Epworth Leagues, or Christian Endeavor societies have a session. and then comes the greatest service of the day-the evening preaching service.

Many of the people who are employed as cooks or housemaids-people in service-do not "get off" until the Sunday dinner has been served at the homes of their white employers, yet even this much time in the afternoon meant some relaxation and some preparation for the evening (night) service at the church. Very naturally with so many released from their daily tasks. the evening service is the largest among the Negroes, while it is usually smaller among the whites. We have often attended such services and have noticed that a feeling of suppressed pleasure seemed to mark each black countenance. It would certainly seem that enthusiasm for church going is a lost art among the whites when compared with the weekly demonstration by the blacks. It must be remembered, too, that in country churches evening services are frequently dispensed with during the winter because of bad roads, coldness, etc., but this is made up for by the great attendance at the protracted meeting night services during the summer. In the cities with sidewalks and less distance to travel no such disparity in attendance with respect to the seasons is shown.

In the cities during the week nights or days there are prayermeetings, class meetings, Board of Officers' meetings, Pastor's Aid Society meetings and missionary society meetings. Marriages and funerals also interest the blacks and are usually well attended. These strictly business or religious sessions are often supplemented by social affairs and the result is that nearly all of the after working hours' time of the Negroes is about to be monopolized by the church. And, indeed, if we take into account the prominent place taken in their thought 
life by the church and its beliefs, we can see conditions which remind us at least of some features of the seventeenth century in Scotland or the Middle Ages in Europe. It would be painful to think that religious services were not congenial to a people who spend such a considerable portion of their lives as the Negroes do in attending them.

The Negro church service usually begins in song and the prominence given music is perhaps the most noteworthy feature of their services. The man would have to be absolutely deaf not to be interested in the weird, almost doleful tunes that the Negroes sing with such pleasure. There is something soothing about them. Few tasks could be more difficult than that of writing on paper just how their old time melodies sound. There is nothing in the music ordinarily heard by the white people to which this music can be compared. Minors are brought out strongly and the peculiarly placed accents and rests give the total effect of something between a chant and a funeral dirge, yet the music has other wonderful effects that make it more than ravishing to the Anglo-Saxon ear. The modern hymns show few effects of such treatment and have few features worthy of remark, but when a "spiritual" has been begun and the venerable "uncles" and "aunts" of the long ago stir in their seats and take notice, one may rest assured that he has not heard some of the most remarkable music in the world, if he has missed this. The choirs singand they are proud of their choirs-each individual claiming that his own church has the best music, but the appeal does not come through them. They interest the black worshippers, but do not delight them. We have frequently attended their services and considered the singing entirely disappointing until one of these old favorites had been started and then all previous misgivings gave away in the presence of the fact that they could sing if they would. Many Negroes soon after the war endeavored to discard the old songs because they considered them reminiscent of slavery, but such a tendency should be immediately arrested as entirely derogatory to the race's best interests. Such favorites as "Steal Away," "Swing Low Sweet Chariot," and "On Jordan's Stormy Banks I Stand" should be immortal. The "spirituals" are predominant among the Ne- 
gro's greatest assets, and it would be a national tragedy should they be forgotten by the present or future generations.

Before the Pastor takes an active part in the church service the Negroes usually meet and have a song service. During this preliminary service the numbers are not called out, but some singer starts a hymn and sings perhaps a whole line before the others make out clearly what it is, or before they are prepared to add to the volume. When this piece is thoroughly under way it is carried on until the end and then there is a silence for a minute or so until another singer starts up something else. Thus it goes until the preacher takes his place in the pulpit and announces a hymn. He "lines" it out for them frequently. We have heard thus read the whole hymn, then return to the first verse and read two lines (line them) which is followed by that much singing. then read two more lines, etc., etc., until the end is reached. This method enables even those who do not read to catch the words, and also calls attention to the import of the song as well as to the music. When the preacher can line them well the result is very impressive.

The Negro has a musical ear. Very few rehearsals find him qualified to "bear down" on a song. This aptness to learn music has inspired some ingenious composers of songs to go from big meeting to big meeting, singing their compositions and then selling them at so much per copy. A good singer, usually termed a "Professor," who has a song with some swing to it can realize quite a neat sum at such a gathering. This type of song is well illustrated by a printed sheet that was purchased from Rev. J. O. Seay, who is a janitor at one of the Chemical laboratories at the University of Virginia, and is also pastor of a little flock near Charlottesville. His song entitled "City of Refuge" exhibits the well-known tendency of

4. Inside View of Slavery, C. G. Parsons, M. D.: "In the early history of our country when books were scarce and expensive, our forefathers were in the habit of singing at church without hymnbooks,-the minister reading aloud one line at a time and then the congregation joining to sing it." Thus in things musical the Negro is travelling the road our fathers trod. just as some Negro churches to-day exhibit emotionalism, as the whites exhibited it during the last part of the eighteenth century. 
Negro preachers to dwell especially on the prominent Old Testament characters.

1. "The decree was signed by Darius. and then, Daniel was cast in the Lion's Den;

God sent an angel on his accord.

He came and locked the lion's jaw.

Chorus.

"I am going to run. I am going to run,

I am going to run to the City of Refuge, I am going to run.

2. "Job was a man whom God did love: God gave Job a home above,

The time came he had to die, Then Job was taken up in the sky.

Chorus.

3. "Elijah and Elisha they went together, God took one and left the other Elijah looked and did aspire He saw the chariot and the horses of fire."

Chorus.

A new Testament character is thus introduced in the last verse:

9. "They put John in a kettle of oil

God was with him and he never got soiled

With hallowed power, the angel came

Went into the kettle and cooled the flame."

Chorus.

Another important feature of their singing throws much light upon a certain form of literary composition. The students of the ballad have a theory that the fine old English ballads, of which we have survivals in this State, were not the result of the authorship of an individual but were the outcome of community authorship. Anyone who will take the trouble to attend a Negro church during big meeting times will hear com- 
munity authorship of hymns going on in his very presence." For instance, in certain songs the mere substitution of a different name enables them to sing again the whole stanza without feeling that they are repeating. The most ignorant kitchen servant might by such means contribute to the most beautiful songs. That this has often happened no student of Negro church music can deny. In such a song as "Peter Go Ring dem Bells" "we see these possibilities exemplified, viz:

"Oh, Peter go ring dem bells

Oh, Peter go ring dem bells

Oh. Peter go ring dem bells

I heard from heaven to-day.

I wonder where my mother is gone

I wonder where my mother is gone

I wonder where my mother is gone

I heard from heaven to-day.

Chorus.

I heard from heaven to-day

I heard from heaven to-day

I thank God, and I thank you too

I heard from heaven to-day.

"I wonder where Sister Mary's gone

I heard from heaven to-day,

I wonder where Sister Martha's gone

I heard from heaven to-day

Its good news and I thank Cod

I heard from heaven to-day

$O$ Peter, go ring dem bells

I heard from heaven to-day.

Chorus.

"I wonder where brudder Moses gone,

I wonder where brudder David gone, etc.

He's gone where Elijah has gone," etc., ad infinitum

5. For this conception of the composition of some Negro church music we are indebted to Dr. C. Alphonso Smith, Edgar Allan Poe Professor of English at the University of Virginia.

6. Hampton and Its Students, by M. F. Armstrong and Helen W. Ludlow, pp. 174, 175. 
We have said in a previous chapter that the Negro is mighty in prayer. This is true whether it is made to apply to men or women. We have heard young Negro women frame prayers that would do credit to many theological students. If theirs was not a baring of the heart, we never expect to hear words paint a picture. Frequently, such prayers are repetitious and almost without exception characterized by imagery. This is one form of service in which the Negro church is superior to the white. Many Negroes in a single congregation are always prepared to "put up" a prayer when called on. The preacher arranges the first part of his service so that there are several songs and several prayers. Sometimes there is little more difference between the two than that which exists between choruses and solos. Such church prayers always become "singsongy." The first part of the prayer is uttered in normal tones, and after a minute or so the calm utterance gives place to the half singing element which constitutes the main body of the prayer. At a place near the end the change from the climax comes suddenly and the quiet speaking voice is again resumed until the Amen is said. During the main body of the prayer the whole congregation rises on the wings of faith with the person who is praying and all are ready in spirit to aid the suppliant as he wrestles with the Almighty. We have heard as many as ten "Amen's" and several "God grant it's" at one moment while such a prayer was in progress, and such encouragement is doubly dear to the heart of the Negro. Soon after he begins his prayer the Negro seems to be delighted that at last the Lord in Heaven lends an ear to his supplications. He is transformed. The same Negro that we saw driving a white mule during a summer's day was standing before the congregation that night with all the sense of importance of an ambassador plenipotentiary as he poured out his tale of human woes and earthly sorrows into the ear of the Infinite. The pathetic element in his voice was comparable to a funeral dirge and his intonation was as dreamy and sonorous as a twilight song. The scene was so realistic and his tones so moumful, that if the man had been condemned to suffer the sorrows of the damned and had suddenly been informed that he might es- 
cape punishment if he pleaded powerfully enough with his judge, no more pathetic, appealing element could have characterized his voice. There were fervor, supplication, humility. an acknowledgment of sin and a thankfulness for escaped pitfalls in such prayers, that cannot be expressed by Anglo-Saxon lips : it is the Negro's province and in it he reigns supreme.

Dr. Howard W. Odum ' has written out two prayers uttered by Negroes that accord so fully with our experience while in attendance at their services that he shall quote them as models. The italics indicate the intoned portions: "O Lord, to-night our Fadder, we thank thee for the privilege which thou has promised us to engage in this hour for the express purpose of having us to worship thee with reverent prayer. Most holy. Fadder, besides thee we know no other name whereby we can be saved. Most holy God, our Faddcr, our Fadder, you haz'e said in yo' most holy and aritten a'ord that where one or two or threc o' yo' believin' servants come togedder you acould be in de midst of yo' chilluns. And Oh, Oh, Jesus, we aisk you to come into this little 'sembly an' endow us with thy spirit. We'sc but frail creatures an' coil, we doan feel worthy o' callin' on you to-night, our heavenly Father, we doan feel worthy o' callin' on thec, but we ask you to-night to come into our midst. $O$ Lord, bless them that's not here, hover 'round them the arm $o$ 'protection. Wc ask you to bless the sinner to-night an' the gambler an' we ask you to bless the dancin' women. We thank thee to-night. our Fadder, that las' night we did not lay down on de bed $o$ ' death an' acake up this mornin' in the mornin' $o^{\prime}$ judgment. $O m y$ Lord, wouldst thou be pleased to remind me to-morrow the sun may rise on my grave. An' $O$ Lord a'ouldst thou be pleased to bless yo' servant to-night who's been waitin' so long. Oh, oh, my Lord, thou divine and heavenly Father. God of the acorld an' tender lowe. please hear yo' seriant tonight. Oh, oh, my Lord sometimes aec try to acep but a'e can't weep: come down to-night an' weep wid us; O Lord, tonight, our Fadder, sometimes we try to sing an' we can't sing; come down to-night, our Fadder, an' sing arid us-

"Now, our Fadder, when we done tolin', when we done meet-

7. Social and Mental Traits of the Negro, pp. 69-72. 
in,' when we done minglin' here, when we don't 'tend no mo' meetin's when we'se done comin' to dis ole church-save our souls is the petition of yo humble servant, for Chris' sakeAmen."

A woman's pathetic prayer: "Oh-oh-Lord, to-night, blass the basterin' child, achereicr he is; Oh-oh-Lord, bless $m y$ mother's children scattcred in foreign lands: oh-oh-Lord. bless my sister's children to-night. Oh-oh-Lord, you know's my heart an' you know's I wants to do right: oh-oh-Lord, give me clean hands an' clean heart, an' oh-oh-Lord, you has blessed me befo' arhen I prayed an' you has promised to bless me ag' in if I come in de right spirit an' $\mathrm{Oh}_{2}$-oh-Lord, to-night bless me: an' you has promised to have mercy on yo chilluns an' it does seem like a'e need mercy over this lan to-night . . . ." Such pathetic prayers indicate magnificent possibilities if we could only be sure that the persons who uttered them lived proper lives, but frequently we have been assured by friends attending meetings with us that So-and-So who prayed so long was a grand rascal. There are more, however, who are mighty in prayer who live exemplary lives. It must never be overlooked that some Negro preachers do not pray typical Negro prayers, but speak as calmly as the white ministers. Even in such instances the "amens" are frequent, but the excitement is less and the volume of sound not so great.

After the singing of several hymns and the prayers are finished the preacher reads the Scripture lesson. chooses his text and preaches. Negroes are natural preachers. There are many degrees of men who have entered this holy calling, varying from the "pot liquor" preachers who gladly rant for the sake of a meal, to the educated. higher class Negro who really does his race much good by his excellent example and splendid Gospe! messages. There is generally an abundance of preachers, and sad to relate, many are not worth their salt. A single congregation will frequently have several local preachers and is also subject to the occasional visits of a tramp preacher. The tramp preacher comes into a neighborhood with his hand-bag, preaches a sermon, is not a real element in the community in which he works perhaps once a month, accepts his pay, and then hies off to other fields only to return after another interval. Community 
life and leadership cannot be built under such adverse circumstances. The rural districts are the real sufferers from this kind of minister as well as from those who know no farming or practical business. ${ }^{8}$

The sermon matter is usually a mere recitation of some Bible story with some well-pointed morals. There are certain timehonored texts which have grown familiar to all hearers from constant usage, yet these are allowed little rest. The sermon begins with very calm statements, but this feature of their worship is not different from the others in that, as time rolls on, the enthusiasm rises. The rousing effect of the spirited songs and the intense emotions aroused by the prayers have not fully subsided before the preacher leaves his calm. quiet manner and appears in the role of a dispenser of "rousements." He tells of the examples set by men of old, rarely omitting Elijah and the chariot of fire, or the three Hebrew children in the fiery furnace, and eventually approaches a climax in which all his hearers are taken up to walk with King Jesus on the streets of gold in Heaven, the home of the redeemed. During this mental ascent from the toils and ills of this life to a home of rest and happiness in the skies, the hearers have hung upon every word, not to weigh its value, but to give assent thereto. In an atmosphere of excitement the effect of the sermon is usually measured by its appeal to the emotions. Never does a man appear before a more sympathetic audience than when he appears before a congregation of Negroes. Whether the preacher be white or black the Negro listener gets into the service by lending him encouragement. As his enthusiasm rises, theirs does too. It is a wonder that the preacher can think, amid such coaching, yet the Negro preachers seem to glory in these exclamations: "Talkin'," "Tell "em "bout it," "Preachin" now." "Yes," "He's right. too," "Um-huh," "Ha-ha." "Talkin', preacher," "Preachin" de word," "Amen,-Amen," "Lord God," "Lord help us." Many other ejaculations one hears, especially from the amen corner, although that place has no monopoly on the output. We have heard one woman cooing like a dove, another clapping her hands,

8. The Future of the American Negro, Booker T. Washington, pp. 29, 30. 
still another patting her feet, and have been convinced by the shaking of heads and swaying of bodies that the intensity of such a scene must be a tremendous strain upon the worshippers.

It is inevitable that some poorly prepared men should be ordained. Congregational government accounts for many of these instances. One old Negro who thought that the mystic letters G. P. meant go preach was later informed by his disgruntled congregation that the letters really meant go plow, and the chances are about a thousand to one that the congregation was right. "Calls" are constantly coming to Negrues. A Negro that we have seen in Hanover County declared that an angel of the Lord appeared to him and seemed to be standing in a window in the elements on the occasion when his call was received. Booker Washington relates in his autobiography. "Up from Slavery," the process of falling out on the floor of the church in his home town when such "calls" came to the Negroes who had learned to read, and he feared that after he got his education a "call" would come to him also, but he was spared." The work of the minister has long since been considered a sinecure by the Negroes and the high-flown talk and imposing strut of the ignorant Negro preacher are too well known to need comment. We have not found, however, that the Negro preachers who are active at present oppose manual labor as some have contended,10 but their influence has been quite to the contrary. Undoubtedly some men did go into the ministry to dodge hard work. Booker Washington tells of such a case (undoubtedly imaginary) in which this factor was potent. He says a colored man in Alabama, one hot day in July, while he was at work in a cotton field, suddenly stopped, and looking toward the skies, said, "O, Lord, de cotton am so grassy, de work am so hard, and the sun am so hot dat I believe dis darky am called to preach." 11 How different are such motives for entering the ministry from those seen in the definition of a "call," as given by Dr. E. M. Poteat, President of Furman

9. Up from Slavery. Booker T. Washington, p. 82.

10. Educational Review. March 1901. p. 241. P. B. Barringer. Also, The American Negro. Wm. Hannibal Thomas, p. 68.

11. Up from Slavery, Booker $T$. Washington, p. 128. 
University. Dr. Poteat in a letter to us wrote: "The man who has come to a deep consciousness of God and his own sin and of the sins of his own people and has had experience of the cleansing grace of Christ and of yearnings to help in the great work God is doing in the world is probably called to be a preacher. I say probably for the reason that it is not certain that he is called. If there are no defects or hindrances he ought to go into the work of the ministry." We venture to say that few indeed among the Negroes have risen high enough to be influenced by such a factor as President Poteat has stated; yet by means of the efforts of missionaries who hold institutes, deliver lectures, and give study courses, the work of the Negro ministry is being pictured in its true light and many worthy Negroes are now undertaking the duties of the ministry as a life-work.

If the old adage is true, "Like priest; like people" then the responsibility is great to see that the Negro preachers are good leaders. Public sentiment must do this, and it can. The intemperate, dishonest, lecherous, ignorant Negro preacher is destined to go when public opinion is thoroughly aroused. Only intelligence awakens public opinion; ignorance lulls to sleep. Not even the sacred precincts of the Negro preacher's home will be free from the peering eyes of the world, and his home life must be as nearly ideal as possible to satisfy the public's demands. Emotionalism, self-glory and corrupt politics must be promptly eschewed and the effort must constantly be made to be at peace with all men. Conciliation will win where a grim insistance on rights will merely meet rebuff. The preacher's whole life must be lived before men so that he can be instantly accountable for every deed without fear of shame or compromise. One ounce of example means more for the $\mathrm{Ne}$ gro's uplift than tons of print or oceans of vocal torrents.

The Negroes of Virginia have had many talented ministers in their midst since the War. Rev. Harvey Johnson born in Fauquier, Rev. C. C. Vaughn born in Dinwiddie, Rev. Christopher H. Payne, Rev. James H. Holmes, pastor of a church with nearly 5,000 members, and Rev. John Jasper of "Sun do move" fame have been among their best-known religious lead- 
ers of the recent past. We shall choose, for brevity's sake, only two of the present day ministers for mention in this place: one from the strongest denomination and the other from the eleventh. Rev. A. Binga, Jr., a Baptist preacher of South Richmond, is now a man of some years. but his vigor of intellect seems unabated and his excellent character has won for him the universal esteem of the sound thinking people of Richmond. His influence is positively for good and this State would be fortunate to have more such reliable men as leaders of the Negro race. Concerning a volume of sermons which Rev. Binga published, the distinguished Southerner. Dr. J. L. M. Curry, wrote: "My dear Brother: With your letter of May 3d came the volume of Sermons. Frequent absence from home and much work have prevented an early examination of the book-Now I write to express the pleasure and instruction I have derived from your 'offering to the cause of Christ.' In many respects, the Sermons are unique and valuable. because of real ability, of evangelical orthodoxy, of excellent spirit. and as proof and hopeful augury of the advancement of your race. I shall treasure this volume of sermons as the production of an esteemed brother." We believe that there are many other preachers who might be mentioned for their intellectual ability as makers of sermons, but W. E Nash, a minister of the Disciples of Christ, by his excellent bearing and forceful message not only served his own people faithfully, but also won his way into the hearts of the white State Convention of that brotherhood which met at Lynchburg in September, 1913.12 At the conclusions of his address some were heard to say, "Others have done well, but the "brother in black' excelled them all" and Judge Garnett of Tidewater Virginia suggested that if black men could preach like that we needed to black up a few of the white ministers. To deny the capacity for uplifting service to such men as these would be little less than criminal. The problem is, how to get more such men.

We can see no possible solution except along the line of intelligence. The letters which tell of the first definite attempts

12. Report in Christian Monthly. October, 1913, p. 7. 
to educate the Negroes for the ministry in schools are absolutely pathetic.13 As Dr. Colver said. "We almost have to make the mind to instruct." Soon after the war such a statement was hardly an exaggeration. It was at least a very popular fallacy if it was. At Fredericksburg in 1870 the Virginia Baptist State Convention (Negro) went on record as anxious for a better educated ministry, when a corresponding secretary's report boldly said: "One great hindrance to the cause of missions in the State, is the want of an intelligent ministry. Tire population are in darkness, and many of the ministering brethren are not prepared to enlighten them. Let the Convention instruct. or advise all the brethren to devote as much time as they possibly can to study, in order that they may be better prepared to the work of the ministry, in edifying the church and perfecting the saints." 14 Nothing is more persistently urged at these conventions than the improvement of the ministers. In the long run the community which is blessed with a well trained, intelligent Negro minister is likely to show progress along other lines and the community which is cursed with the opposite type of minister is likely to be filled with despair. ${ }^{15}$ The country preacher should know how to plow as well as to pray; the city preacher should know sociology as well as theology. As intelligence in the pews becomes more prevalent among the Negroes, a ministry must rise to the occasion. The intelligent Negro laymen are asking for bread and they will not be content with stones. Pulpits characterized by emptiness of ideas and fullness of sound will not ever remain popular. No feature of Negro church life is more deplorable than the carelessness sometimes manifested in ordaining men to the ministry. The Negroes will follow; they must have leaders who can and will lead. Just here is where the modern Negro has his chance.

The primitive type of preacher is the most popular at pres-

13. History of the Richmond Theological Seminary. C. H. Corey, pp. $62,63$.

14. See Baptist Year Book. 1871.

15. The Demand and the Supply of Increased Efficiency in the Negro Ministry. Jesse E. Moreland. 
ent. A new type, however, is fast evolving. This new type of preacher will hardly attain to the popularity of the old style minister, but more good will be done by his ministry. At present, the college minister is laboring over form. His gestures, voice effects, appearance, etc., are important matters now, but he is surely improving. The habit of borrowing sermons and trying to lose his identity in the white man's no longer enthralls him. High ideals are inculcated in these men at their colleges and they are leaders in cultivating race pride after they have accepted a pastorate. A few of these young preachers are silly enough to antagonize the whites. but this minority is not influential and is almost universally decried by the real Negro leaders. A saner type of Negro preacher is here, and it is entirely becoming that the white people should recognize his worth and give the credit where it is due, or at least distinguish between the bad and good among them sufficiently to place no crimes, or even blame, at the doors of the innocent.

After the singing and praying and preaching portions of the service have been concluded, we see something that makes us think that the climax has come. Generally some "gifted" speaker, a church officer, stands near a table placed in front of the pulpit and makes an appeal for money. The nature of this appeal is frequently anything but elevating. The object seems to be to get the people in good humor. The choir usually sings during the offering. The method of giving is for the giver to leavo his seat, walk up to the table at the front of the church, place the money on the table, and then return to his seat. Naturally, some of the belles desire to make many trips to the table to show their charms, and this process leads to small deposits on each trip, but a surprisingly large total. As a man who "lifts" a collection continues his plea for more money the Negroes have been known to give their last cent, and the surprising thing of it all is that the amount that they set out to raise is usually raised. "We must have ten dollars on this table to-night" the collection "lifter" announces and ten dollars is very likely to get there. After all have been given an opportunity to come to the table, the baskets or hats are passed through the congregation to gather up the remnants. The 
counting of the money has been going on during all this time and the services are about done.

The objection has been made that the collection coming after the sermon leaves little of the impression of the sermon on the minds of the worshippers." Spiritual truth has few chances to survive through some of the jokes and jibes incident to "lifting" a collection. The dignity of the service is thus rudely shocked. But the Negroes do give. The whites have not approached them in this matter of liberality. With the Negroes it is an every member matter. The regular yearly expensesassessments-are met and a host of special offerings are constantly being received. The congregation is divided into teams and the pride of the victorious captain is almost unbounded. When these teams begin fighting it out in a $\$ 77.52$ rally or a $\$ 300.00$ rally the amounts somehow mysteriously arrive. Sacrifice accounts for much of their success, yet the cynical declare that the cook's basket, a national institution, explains much of the mystery. One thing is certain, the proverbial chicken thieves among the Negroes are fewer in number at present than formerly and even if it is a temptation to the Negro to attach a rooster to himself occasionally, so the deposits of a bank or a railroad are temptations to the white man, and we frequently punish one as severely as the other. The lack of proper influences is seen in every word uttered by a Negro maid to her mistress when caught stealing, "Law, mam, don't say I'se wicked; old Aunt Ann says it allers right for us poor colored people to 'propriate whatever of the wite folks blessin's de Lord puts in our way." Petty thefts are foolish for property owners to think about. Hard work certainly accounts for most of the money paid into the church by Negroes, and none of the glory of their liberality should be minimized by carping on an occasional departure from the paths of rectitude. We have ascertained from letters sent to the leading white denominational.mission boards that considerably more than a million dollars have been contributed by them to various forms of educational and church work in Virginia. Individual whites have added many more thousands to this grand total.

16. Reforms in Negro Church Worship. A. Binga, Jr. 
These services continue until late in the night, and when the benediction is pronounced, it is time that the worshippers should rest.

No one could describe a protracted meeting-"big meeting" -because words fail to convey an adequate conception of such accasions. The most interesting of such meetings take place in the country during the month of August. A "big" city preacher is usually called on to do the preaching and these services last for a week or so during much of the day and frequently up to midnight. All of the phenomena seen in city churches are heightened and enlarged in the country meetings. Du Bois has expressed some of the intensity of such an occasion in his much quoted lines: "A sort of suppressed terror hung in the air and seemed to seize us-a pythian madness, a demoniac possession, that lent terrible reality to song and word. The black and massive form of the preacher swayed and quivered as the words crowded to his lips and flew at us in singular eloquence. The people moaned and fluttered, and then the gaunt-cheeked brown woman beside me suddenly leaped straight in the air and shrieked like a lost soul, while round about came wail and groan and outcry, and a scene of human passion such as I had never conceived before." 1 "

The all-day meetings draw attendants from even the surrounding counties and a dinner is spread which shows ample provision for all. Fried chicken, roast pig. pickles, a "mess" of cabbage, potatoes, several kinds of bread, fruit, pies, cakes and other things go to make up the feast. Much happiness is manifest during this recess and then the afternoon service begins quite languidly. The service is eventually over and when inquiries after friends and acquaintances are done, the church grounds are deserted until another service. The baptizing generally takes place at the conclusion of the big meeting and administering of this rite is ordinarily a fitting climax to the wonderful outburst of religious enthusiasm. It would be impossible to mention protracted meetings held in Virginia by Negroes without stating a few of the salient facts in connection with the great revival held in Norfolk during 1911. A Negro

17. The Souls of Black Folk, W. E. B. Du Bois. p. 190. 
preacher named F. W. Williams, pastor of the Queen St. Baptist Church, had a "vision from God" on New Year's Day, and a simultaneous revival began in several of the Negro churches in March. It so happened that Rev. Dr. C. S. Morris, a distinguished Negro from the North, came to Virginia at this strategic moment and immediately became the man of the hour. The ten weeks revival was greatest at his church. One night 296 Negroes were converted: another 211 ; another 111 and as many as $\mathbf{5 0}$ or more a night were not uncommon. Negro dance halls that did a three hundred dollar business each night recorded only five dollars, saloons were practically empty, gambling was checked, the police court had no Negroes on the docket: "Big Hughsie," one of the black gambling leaders. was converted and urged all those whom he had taught to gamble to raise their hands; at least a hundred hands were raised. This man was arrested the same night for praising God on the streets, but was later bailed out; the American Tobacco Company had to lay off its hands because of the religious frenzy; the Farmers Manufacturing Company had a similar experience; everywhere from kitchens to wharves the influence of this meeting was felt. It was practically a singing revival. Thousands of whites gathered to hear the music. "He loved me so" and "I love Him" to the tune of "Old Black Joe," were the greatest favorites. None but sinners were allowed in the body of the church and these were converted to the number of 1,500 or 2,000. The revival did much good in Norfolk, and brought to light the fact that the Negroes have an exceptionally efficient leader who suffers no compromise with evil himself and is especially powerful in securing the co-operation of the white ministers of Norfolk. ${ }^{18}$

The local associations and the State conventions are wellattended as a rule, and many visitors are in evidence. The Negro preachers are usually dressed their best and the church that entertains them is prepared for a great event. Many of the Negroes in attendance speak and many special sermons are provided for on the program. Debate often waxes warm, and

18. For iurther details see Norfolk Public Lcdgcr, April 21, 1911, et passim. 
the conventions are usually well-conducted and handle business as expeditiously as could be expected. During a convention held recently in August an address of welcome read by Sister Lula R. "offered the Association first of all the Church, then extended this offer to the homes, tables and still further for feather beds which things have always and everywhere appealed to ministerial dignity." And all of these things were duly enjoyed by the Convention, too.

We have said in our preface that many letters had been sent to various individuals in different parts of this State. These letters were sent for the purpose of collecting data on certain phases of our subject. Facts are fundamentally important for history: yet the facts are rarely so influential as what men believe about those facts. What the Negro is and what people think about him may be very different, yet what the people think will be the thing of inestimable importance in influencing our attitude, towards the Negro. We have striven to learn what many kinds of people in many kinds of places in this Commonwealth thought on certain matters pertinent to the question. To the white citizens we wrote the following schedule of Questions:

I. 1. Is the moral condition of the Negro improving or not?

2. Are the Negro ministers in your community good or bad men? Name two or more virtues or vices.

3. What do you think of the religious life of the Negro?

4. How can the Negro Church be bettered?

5. To what extent have Negro preachers mixed in politics in the past? Are they influential now?

To the Negro preachers this schedule of questions was sent:

II. 1. Are your members active in the church? Give percentage.

2. Does your church encourage domestic science, normal training?

3. What is the influence of the exhorters and leading members?

4. Do people shout in your church? Do you oppose it?

5. Name three favorite hymns. 
6. What are your greatest difficulties in church work?

7. Suggestions for bettering the Negro church.

The Negro laymen were requested to answer the following schedule of questions:

III. 1. What is the condition of the Negro churches in your community?

2. Are your ministers good men? Name virtues or vices.

3. Are the young people interested? Is your Sunday-school growing?

4. Do you think sexual immorality is increasing or decreasing?

5. Name some of your churches' charitable works.

6. Name three favorite hymns.

7. How can you better your churches?

We were sure before we sent out a single question that the results to be obtained from these letters were not to be strictly reliable. In the first place. men are prone to be very charitable when they write out answers to such questions. far preferring to err on the side of charity than run the risk of being considered prejudiced. In the next place. men of vastly different ages received these letters and the age of a man ,is generally indicative of his answer when it concerns the Negro question. In the last place, all the questions sent out to the Negroes were sent to the best educated Negroes, usually college Negroes, because we were unable to obtain the names or receive written answers from illiterate Negroes. ${ }^{19}$

Several of these questions received such uniform answers as to make discussion of them unnecessary, but we shall consider them seriatim to prevent confusion. Schedule I, question one, received 152 answers indicating that the Negro life is improving morally, 89 answers that it is not improving morally, and ten answers that indicate uncertainty. Where there were few Negroes, or near their schools, the answers showed improvements,

19. It must be borne in mind, however, that we held many conversations with illiterate Negroes in order that their view-point would not be overlooked in this study. 
but where Negroes lived to themselves mainly as in the black counties the answers indicated no progress. Nearly every doctor expressed his belief that they were not improving, but this was what was to be expected from this profession which deals almost entirely with their ills.

Schedule I, question two, received a majority of answers indicating that the Negro ministers were good men and were above the average of their race. It is not likely that unanimous approval would be given even to white preachers. Among the virtues or vices shown in the letters, honesty, sobriety, industry. promoters of better understanding between the races, quietness, respectfulness, and charity of one class of preachers, vie with drunkenness, sexual looseness, dishonesty, ignorance, stealing, fomenting racial unrest and disregard of obligations of the others. It is to be hoped that these criticisms will renew the zeal of the good and correct some of the faults of the bad religious leaders.

Schedule I, question three, found a big majority of the white people without faith in the religious life of the Negro. Such expressions as the following are characteristic of the answers: "too emotional," "form only," "have little idea what religion is,"."do not think religion has much hold on the race," "an inlet for good, an outlet for emotion, a field for activity," "spectacular," "religion only on Sunday," "comes by spells," "outward profession instead of upright lives," "unknown quantity," "little benefit," "spasmodic," "not rational." "do not fully appreciate what true religion is," "little religion other than what is shown," "mostly superficial, emotional and borders on superstition," "better what they have than none at all." In spite of the overwhelming majority of answers indicating a low opinion of the religious life of Negroes, some declare that they believed that the Negroes' religious life was showing improvement, while others were frank to confess that they did not know.

Schedule I, question four. This question gave opportunity for a wide expression of opinion and this opportunity was certainly grasped. A plurality of answers suggested better. education for the ministry and better education for the pews. 
While next to education the answers showed that some form of co-operation or supervision on the part of the whites would be the best way to effect the laudable end of bettering the Negro church. Fewer answers were received to this question than to any other: which would seem to indicate that constructive work was not so popular as the destructive or laudatory. "Too deep for me." "can"t answer this." "cannot say how," "can make no suggestion at present" and many blank spaces show further that this matter has not been considered important enough for some to form any opinion concerning it.

Schedule I. question five. It received an almost unanimous answer. It was agreed that the Negro had been influential in politics before the Constitutional Convention of 1901-02 disenfranchised practically every individual of the race, but since then the Negro has not counted in politics. We have shown exceptions in "wet" and "dry" elections and in cases of a close vote.

In schedule II the Negro preachers showed a commendable spirit in answering the questions. Some of them were afraid to answer but most of them showed great consideration. The result of these answers we shall now present.

Schedule II, question one. By computing the percentage from the figures sent to us we find that the Negro preachers consider $36 \%$ of their members active. Some abnormal conditions raise the figures to this large number. For instance. some of the Episcopal churches report as high as $95 \%$ of their members active. The Presbyterian churches also show a large percentage of active members, while some of the large Baptist churches show only 25,33 , and 40 per cent. Perhaps if returns were had from all the churches in the State the average would be found somewhere near 40 per cent.

Schedule II, question two. Without exception the Negro preacher declared themselves in favor of training their race in domestic science, and conducting normal training classes for the Bible school work and day school. Many of them indicate that their congregations are largely composed of "people in service" and these are especially interested in these splendid educational features. 
Schedule II, question three. The exhorters are considered helpful by $90 \%$ of the preachers and they are commended for their excellent lives. The remaining ten per cent declare that the exhorters are ignorant, immoral and in the way of progress. It seems that the young college graduate finds it especially difficult to change the old-style manner of worship because of these "big" members. In some of the churches in which ignorance is rampant the exhorters negative with their lives all that they proclaim with their lips.

Schedule II, question four. About seventy-five per cent of the answers to this question state that the worshippers do shout and about fifty per cent of the preachers oppose shouting. Those ministers who do not oppose it consider the shouting splendid when it is "real" or "prompted by the Spirit," and the hearers "touched by the word of God" and "enthusiastic in religion." Not all of the churches offer much temptation to their members to shout. and the less temptation offered the better. We have seen that the whites criticize the Negro religion especially for its emotionalism: we have seen that the whites shouted, too, in the past, and a few do yet. The sooner the Negroes cease making their worship a spectacle the better for the race. A well-trained minister will solve this problem of shouting.

Schedule II, question five. Much to our surprise none of the old "spirituals" were mentioned in the list of three favorite songs. Of the favorite hymns submitted, the first seven in the order of their popularity are: "Am I a Soldier of the Cross," "Amazing Grace," "Nearer My God to Thee," "A Charge to Keep I Have," "There Is a Fountain Filled with Blood," "Come Holy Spirit, Heavenly Dove," and "All Hail the Power of Jesus' Name."

Schedule II, question six. The fundamental trouble in church work according to a great majority of the Negro preachers is the matter of properly financing the activities, or as one preacher said, "to get my people to understand that God has a claim on our pocket-book." "Lack of promptness on the part of members attending churches," "settling grievances between members," "backsliding," "unavailing efforts to get young peo- 
ple interested," "difficulty in reaching men," "alcoholic liquors," "superstition," "lack of harmony," "keeping officers active and making them progressive," "want of Christian zeal" and many other things are considered the greatest difficulties by different preachers. There are undoubtedly difficulties enough, but the statement of the problems should be of some advantage in attempting a solution.

Schedule II, question seven. The universal suggestion offered for bettering the churches is a better trained ministry. "Grood Sunday-school teachers," "better choirs," "more intelligent laity," "less superficiality and more Christianity, seasoned highly with thrift, honesty, veracity and sobriety," "emphasis on practical side of life," "practical athletic Christianity," "closer touch with white people," "stimulating young people," "clubs to do civic work," "not so much stress on buildings and more on Christian love" are samples of the suggestions offered by the Negro preachers. It is to be hoped that some of these suggestions will be adopted and the Negro church bettered thereby.

Schedule three was sent to the Negro laymen. Their answers are practical and reflect much credit upon those who answered.

Schedule III, question one. Only ten per cent of the answers found fault with the conditions of their churches. Many were enthusiastic in sounding the praises of their organizations. The overwhelming loyal sentiment of the Negroes to their churches is here shown to be operative.

Schedule III, question two. Eighty-eight per cent of the answers indicate that the Negro preachers are good men but others declare that not all are good. The Negro laymen find faults in the good ones and some virtues in the bad ones. On such points their answers are especially valuable. "Profligates and libertines," "after money," "care nothing about uplift work," "keep the people ignorant" and "opposed to internal improvement of the people" are some of the indiciments brought against the Negro preachers by the minority who answered. The majority said that their preachers possessed among others the following virtues: "have higher ideals than 
formerly," "are good, patient, earnest, self-denying men," "good will and respect of the white citizens generally," "sober," "chaste and honest," "good leaders," etc.

Schedule III, question three. Sixty-six per cent of the answers, concerning the interest of the young people and the growth of Sunday-schools, affirm that the young people are interested and the Sunday-schools steadily growing. Much concern is shown because the older people pay little attention to the Sunday-school.

Schedule III, question four. Over ninety per cent of the answers concerning sexual immorality show that it is decreasing. The Negro's opinion concerning this matter and the white man's are entirely different. A better day is in store for the Negro when he becomes ashamed of his excesses, and only when that day arrives need we expect any confidence to be shown in the Negro's religion by the white men. The Negroes were much imposed upon during slavery, but this excuse will not always serve to cover a multitude of sins.

Schedule III, question five. Missionary funds, old folks' homes, orphan asylums, literary funds, educational institutions, "poor saints" and the education of ministerial students are the foremost charities which engage the attention of the Negro church members. Many of the Negro worshippers have little themselves and the large amounts which they give for charitable purposes are all the more remarkable in the light of their economic standing.

Schedule III, question six. This question was answered by the laymen exactly as the preachers answered it. See Schedule II, question five.

Schedule III, question seven. Fully answered in Schedule II, question seven. The laymen lay less stress on the need of the minister, but in all other points in agreement.

Public sentiment is certainly valuable, and we cannot be other than exceedingly grateful to the many people who sacrificed time and thought to these problems. It would have been next to impossible to write concerning the Negro without the contributory evidence sent to us in answer to the above sched- 
ule of questions. This information was not doled out to us in bits or fragments but busy men wrote five, six and seven pages to give the requested opinions.

The much mooted question of the relative religious status of the ante-bellum Negro and the modern Negro can hardly be discussed yet because of the lack of an unprejudiced jury. Men show doubt concerning many things when discussing the Negro question, but no one speaks in uncertain tones when this particular matter is broached. We have never yet seen a Southern white man over sixty years of age who believed that the modern Negro was worthy even to stoop down and unloose the latchet of the shoes of a good "old time darkey." We have never seen a venerable slave Negro who did not look with some disdain upon the "new fangled" notions introduced into the churches by the "young set" whom they seem to regard very often as vulgar upstarts. We have never seen a young, educated Negro who failed to impress us with a feeling that he believed that the old Negroes who advocated the hallelujah type of religion were after all more to be pitied than blamed. Exceptions to these observations undoubtedly exist, but the general rules will not be disturbed. The highest tenth among the modern Negroes is perhaps higher than the highest tenth was among the slave Negroes, and the lowest tenth among the modern Negroes is probably lower than the lowest tenth in slavery days. ${ }^{20}$ In fact, after all authorities have written pro and con. the only course which one can pursue is to state one's personal judgment and endeavor to weigh down the almost evenly balanced scale with it.

The Negro has excellent prospects for his future: it is impossible to argue that his future is behind him. He has exhibited in recent years too many improvements to give countenance to the theory that he is progressing backward instead of forward. In spite of the great effort put forth .by many charitable white people of the South; in spite of the almost parental care shown by many masters; in spite of the interest in the Negro's religious welfare, we are compelled to believe that the

20. Encyclopedia Britannica, Article on Negro, Eleventh Edition. 
proportion of religious Negroes now, who live exemplary lives is as great as that attained at any time during slavery. Seeing frequently depends upon what we are looking for. In slavery days Southern men's eyes were strained to see the good in their servants; now, some eyes are willing to see only the bad. We must remember that the Negro was probably at his worst about 1890 , one generation after his release from slavery. In disregarding the Southern whites immediately after the War he sowed the wind and reaped the whirlwind. Their fathers ate sour grapes and the children's teeth were set on edge. It is true that many good individuals arose during slavery and are now called blessed; it is true that the Negro was protected then from the evils of intemperance; it is undeniable that church services and Sunday-schools held for Negroes did nobly in behalf of the racial uplift. yet the great work of that day was that of laying the foundation for the greater work of their future-and our present. Many modern Negroes have proved themselves unworthy to be recipients of so many Christian labors, but many more have shown by their deeds that not one iota of the Christian labors expended on them has been misplaced. The history of our Commonwealth is already replete with the stories of noble deeds and substantial progress, but if some future historian can confirm our judgment that the religious development of the Negro in Virginia showed marked advances even in the period since slavery, we shall be more than happy in the knowledge that the task of our forefathers did not fall upon unworthy shoulders. 


\section{BIBLIOGRAPHY.}

The authorities given in this list are primary and by no means include the greater mass of material which is considered secondary. This Bibliography does not pretend to be a complete bibliography on the Negro question, but includes only those records used in the preparation of the foregoing study.

\section{Mantscript.}

A. County Court Records-Orders, Deeds, Wills, Inventories, etc., certified copies transcribed from the original records in pursuance of an act of the Virginia State Legislature and preserved in the Virginia State Library in Richmond, Va.:

York County.

Henrico County.

B. County Court Records,-Orders, Deeds, Wills, etc., originals.

Northampton County at Eastville, Va.

C. Parish Records.

In Bruton Church, Williamsburg, Virginia:

Register of Middletown and Bruton Parishes, 1662 1797.

At Library of William and Mary College, Williamsburg, Va.

Register of Abingdon Parish, transcribed by Dr. Lyon G. Tyler.

D. Records of Friends' Meetings at Park Avenue Meeting House, Baltimore, Maryland.

Minutes of Warrenton and Fairfax Quarterly Meeting, 1776-1787.

Minutes of Warrenton and Fairfax Quarterly Meeting of Women Friends, 1775-89.

Minutes of Warrenton Quarterly Meeting, 1787-1801.

Minutes of Fairfax Quarterly Meeting, 1787-1850. 
Minutes of Crooked Run Monthly Meeting, 17821789.

Minutes of Fairfax Monthly Meeting: 1, 1759-1777; 2, 1777-1791; 3, 1791-1811; 4, 1811-1851.

Minutes of Goose Creek Monthly Meeting, 1785-1818; 1818-18-.

E. Records of the General Court of Virginia, transcribed by Conway Robinson, 1640-1661, 1670-1676. Va. Hist. Society.

F. Legislative Petitions of Virginia, 1776-1860.

These petitions constitute virgin soil for the historian. The acts of the Assembly were powerfully influenced by the presentation of a petition praying that certain things be done or certain nuisances be abated. The petitions were valuable in that they let the representatives in the legislature know what their constituents wanted. The more honorable the citizens signing such petitions, the more likelihood of their wishes being granted. Several thousand of these petitions are preserved in the Department of Archives of the State Library at Richmond, Va. The counties from Accomac to Orange are catalogued in upright filing cases; each petition in a separate, stiff paper folder.

G. Transcripts from original papers in the British Public Record Office, London. By Angus W. MacDonald, 7 vols.. 1619-1695; containing abstracts or complete transcripts of 581 documents relating to the settlement and early history of Virginia. By William Noel Sainsbury, 20 vols. 1606-1740: containing abstracts of 5108 documents relating to early Virginia history. Va. State Library.

\section{LAWS OF VIRGINIA.}

1. Statutes at Large of Virginia, 13 vols. 1619-1672. Wiilliam Waller Hening. Richmond, 1819, 1820.

2. Statutes at Large of Virginia, 3 vols. 1792-1807. Samuel Sheppard, Richmond, 1835-1836.

3. Acts of the General Assembly of Virginia, 1807-1865.

4. Codes of Virginia. 
Public Documents.

1. Journals of the House of Burgesses, $1727-1776,8$ vols. Ed. H. R. Mcllwaine, 1905-10.

2. Journals of the House of Delegates, 1776-1865. Richmond.

3. Journals of the Senate of Virginia. 1778-1865.

4. Documents of the House of Delegates, containing the messages of the Governors to the General Assemblies and annual reports of the public officers of the State, and of boards of directors, visitors, superintendents, and other supervisors of public institutions in Virginia. 1814-1865.

5. U. S. Census Volumes, 1860, 1890, 1906.

Excyclop.edias and Directories, Magazines and Minttes, NEWSPAPERS.

I. Encyclopædias and Directories.

A. Encyclopredias.

1. Encyclopædia Brittanica.

2. American Annual Encyclopædia.

B. Directories.

1. Norfolk.

2. Richmond.

II. Magazines and Minutes.

A. Magazines.

1. Virginia Magazine of History and Biography.

2. William and Mary Quarterly.

3. Missionary Review of the World.

4. Popular Science Monthly.

5. Southern Magazine.

6. Educational Review.

7. Methodist Quarterly Review.

8. Religious Herald.

9. Princeton Review.

10. Southern Workman.

11. Sunday-School Times.

12. Christian Monthly. 
B. Minutes.

1. Yearly Minutes of Virginia Baptist General Association (white).

2. Yearly Minutes of Virginia Baptist State Association (negro).

3. American Baptist Year Book.

III. Nëwspapers.

1. The Recorder, Richmond, 1802-1803.

2. The Enquirer, 1804-1864.

3. The Whig, Richmond.

4. Richmond Times-Dispatch.

5. The Public Ledger, Norfolk.

6. The Ledger-Dispatch, Norfolk.

7. The Virginian-Pilot and Norfolk Landmark, Norfolk.

Published Parish Records and Local, Histories.

I. Parish Records.

1. Burton, Rev. L. W. History Henrico Parish and St. John's Church. Edited and Compiled by J. Staunton Moore, Richmond, Va. 1904.

2. The Parish Register of Christ Church, Middlesex County, Virginia, from 1653 to 1812 . Published by the National Society of the Colonial Dames of America in the State of Virginia. Richmond, 1897.

3. Register of St. Peter's Parish, New Kent County, Virginia, 1685-1787. Published by the National Society of the Colonial Dames of America in the State of Virginia. Richmond, 1904.

4. Slaughter. Rev. Philip. A History of Bristol Parish, Va. Richmond, 1879.

5. Goodwin, Rev. W. A. R., Historical Sketch of Bruton Church, Williamsburg, Virginia. Williamsburg, 1903.

II. Local Histories.

1. Du Bois, W. E. B. The Negroes of Farmville, Virginia, A Social Study. In U. S. Bureau of Labor. Bulletin No. 14. Jan. 1898; pp. 1-38. 
2. Forrest. William S. Historical and Descriptive Sketches of Norfolk and Vicinity. Philadelphia, 1853.

3. Lossing, Benson, J. The Home of Washington and Its Association. New York. 1866.

4. Peyton, John Lewis. History of Augusta County, Va. Staunton, 1882.

5. Wise, Jennings Cropper. Ye Kingdome of Accawmacke; or, The Eastern Shore of Virginia in the Seventeenth Century, Rich. 1911.

6. Woods, Rev. Edgar. Albemarle County in Virginia, giving some account of what it was by nature, of what it was made by man, and of some of the men who made it. Charlottesville, 1901.

\section{Books and PaMphlets.}

1. Adams, Nehemiah. A South-Side View of Slavery; or, Three Months at the South in 1854. Boston, 1854.

This book created great interest in the South since it came from the pen of a Northern man and substantiated the position held by Southerners concerning slavery. The facts cited are given as real observations and indicate that none of the atrocities were commonly practiced upon the Negroes as some had represented. The South found great satisfaction in this book and the anti-slavery people much chagrin.

2. Armstrong, M. F. and Ludlow, Helen W. Hampton and Its Students. New York, 1874.

This volume is made up of a number of things. The early history of the School, stories concerning Negroes, results of the work done, buildings, and a section of 85 pages of music are some of the more important features of this book. It is a sympathetic view of Hampton and the Negro which is here presented.

3. Asbury, Francis. Journal of. 3 rols. New York, 1852. This Methodist Bishop did eminent service for his church when the Methodists were merely gaining a foothold on this continent. His observations concerning the people and conditions are made on the spot and prove the Bishop to be a keen 
observer. Like many other Englishmen he was opposed to slavery.

4. Atlanta University Publications. Edited by W. E. B. Du Bois.

No. 8. The Negro Church.

No. 9. Notes on Negro Crime.

No. 13. The Negro American Family.

These studies are parts of a series which aims to cover the Negro question every decade. The works are very valuable as sources of information. They are ably edited and have many contributors.

5. Ballagh, J. C. History of Slavery in Virginia. Johns Hopkins University Studies. Extra vol., No. 24. Baltimore, 1902.

The masterful treatment of his subject by the author is in entire accord with the splendid work done at Johns Hopkins. The field was immense and necessarily some matters were touched lightly. In his fine understanding of the laws concerning slavery and in his fruitful suggestion concerning the status of the first Negroes imported, Dr. Ballagh has shown himself well qualified for the work of a historian. His book is filled with interesting facts.

6. Barringer, P. B. The American Negro: His Past and Future. Chariotte, N. C. 1900.

Dr. Barringer has little belief in the education of the Negro. He picks out much of the worst of the Negro's past and has little or no confidence in the Negro's future. The pamphlet is interesting as an anti-Negro tract, but shows no appreciation of the later developments of the race.

7. Bassett, John Spencer. The Constitutional Beginning of North Carolina. Johns Hopkins University Studies. Twelfth Series VII, Balt. 1894.

Dr. Bassett's work is one of those studies which do so much to help the history of a State. He throws light on matters that would otherwise be overlooked. The statements in his work are well authenticated by good authorities. His work touches the Negro problem in few places. 
8. Binga, A. Jr. Binga's Addresses on Several Occasions. Reforms in Negro Church Worship.

This address was delivered before the Social Study Club of the Virginia Union University, Richmond, Va. The Rev. Binga is a Canadian by birth but has done much for the advancement of his fellow-Negroes in the State of his adoption, Virginia. This address shows that the better Negroes realize the weaknesses found in their churches and are making efforts to eradicate the evils. Valuable for its suggestions.

9. Blair, Lewis H. The Prosperity of the South Dependent upon the Elevation of the Negro. Richmond, 1889.

This work is highly laudatory of the Negro. The writer has some reputation as a pamphleteer. The economic argument is now accepted by the best Southern Whites, but all whites are wary of the social equality elevation. Mr. Blair points out some radical courses and makes some dire promises in case the Negro is not elevated.

10. Blyden, E. W. Christianity. Islam and the Negro Race. This man went to Africa as a missionary and places the Negro on high ground in his writings. There is something oratorical in his style. The book is made up of a series of essays which are thoroughly readable. They burn with devotion to the race and show that the author has had a wide field upon which to base his observations.

11. Bosman, J. Description of the Coast of Guinea. 1705. The author of this book paints a very gloomy picture of Guinea. There was evidently much to justify his painting. His statement of marital conditions and the laxness of morals is especially trenchant. Many phases of the Negro's life are covered in the same manner.

12. Bouldin, Powhatan. Home Reminiscences of John Randolph of Roanoke. Richmond, 1878.

The writer of this book is an able man and his equipment for the task of collecting interesting facts concerning John Randolph was excellent. He has a charming style and narrates facts laughable and serious with equal facility. It is entirely probable that some of his stories may have suffered by 
rough handling since Randolph or someone else spoke them, yet his facts concerning Randolph's life are thoroughly reliable. The volume makes delightful reading matter.

13. Bruce, P. A. Economic History of Virginia. 2 vols. N. Y. 1896.

This work is one of the finest pieces of history writing ever done in Virginia. The book is so filled with details as to make it heavy reading for any but students. Facts are piled upon facts until the least shadow of doubt concerning the author's opinion must disappear. The whole effect of the work is splendid. Money conditions, labor, contracts, and many other matters are ably handled.

14. Bruce, P. A. Institutional History of Seventeenth Century. 2 vols. New York, 1910.

These volumes are invaluable to a student of events during the Seventeenth Century. The author was splendidly equipped for writing history and worked prodigiously. The books are literally loaded with facts. So thoroughly and accurately were his books written that we dare say they are worthy to be used as sources. His handling of the clergy, church and courts is especially fine.

15. Bruce, P. A. The Plantation Negro as a Freedman. New York, 1889.

The style of writing seen in this volume is entirely different from the volumes above. The short sentences of the books above are not seen in this work. The long, sonorous, sentences with their oratorical sweep are now seen. The style is sustained; the subject matter intensely interesting. Many valuable lights are shed on the Negro problem by this book, since the author is an accurate observer who saw conditions before and after. The Modern Negro suffers by his comparison.

16. Burgess, John W. The Middle Period. 1817-1858. New York, 1910.

Dr. Burgess is a text-book writer of note. He has implicit confidence in himself and "sound doctrine" usually means his own interpretations of events. He is very fair in dealing with the subject of Negroes, and is one of the historians (now more 
numerous) who can see the evil in men like John Brown and Nat. Turner. Though he is a Northern writer, the South does not suffer at his hands when he discusses slavery.

17. Butt, Israel L. History of African Methodism in Virginia or Four Decades in the Old Dominion. Hampton, 1908.

The Negro writer of this book is an aspiring black man. He has been championing the cause of his race for years. His part in the A. M. E. Church in Virginia is conspicuous for good. The book is mainly made up of A. M. E. Virginia Convention Minutes which speak volumes for the betterment of conditions among the leaders.

18. Campbell, Sir George. White and Black in the United States. New York, 1879.

A good book of travels. The author was an Englishman and had ideas of pure democracy when color-line matters arose. His ignorance of the Negro problem was shared by many of his countrymen.

19. Castleman, T. T. Plain Sermons for Servants. New York, 1853.

One of the excellent books of sermons published for masters to read to their servants. The writer was an Episcopal clergyman and turned out a valuable book. Its messages would still be beneficial if read to Negroes.

20. Clayton, Victoria V. White and Black under the Old Regime. Milwaukee, 1899.

Mrs. Clayton presided over a splendid Alabama home. Her duties as mistress on the great plantation included oversight of the religious exercises of the Negroes. She, like many Virginia ladies, felt that this task was sacred and she performed it with great care. Much of the best side of slavery can be seen from a casual reading of this volume.

21. Coke. Thomas. Extracts of the Journals of the late Rev. Thomas Coke, LL. D.; comprising several visits to North America and the West Indies, etc. London, 1793. Dublin, 1816.

This Methodist Pioneer visited Virginia frequently and bore 
testimony against slavery. He was an imported Bishop. Rev. Devereux Jarratt aroused his ire especially. Bishop Coke preached to Negroes frequently and his influence must have been in favor of better conditions for Negroes. He makes many notes concerning people and things of his time which now prove interesting.

22. Cooke. John Esten. American Commonwealth Histories - Virginia. Boston, 1883.

This volume is written in a pleasing style but is not strictly accurate. The author believed too much. The historical discoveries of recent years have proved that some of the material accepted by Cooke is not now to be accepted as true. The arrangement of the subject matter is excellent.

23. Cooke, John Esten. Stonewall Jackson. A Military Biography. With an Appendix by J. Wm. Jones. New York, 1876.

An excellent book from a literary standpoint. It does not receive the respect in the military world accorded the valuable treatise by the English officer, Henderson. Rev. J. Wm. Jones has appended some valuable anecdotes and has given some insight into the private character of the great general.

24. Dabney, Robert L. A Defence of Virginia (and through her of the South), in Recent and Pending Contests against the Sectional Party: New York, 1867.

A standard apology for slavery. This book blinded the eyes of many to any good thing in the emancipated Negroes. It is a philosophic treatise as well as a hard, practical argument. The chapter dealing with the ethical aspect of slavery was of particular service in our study.

25. Davies, Samuel. Letters from [him] and Others; shewing the State of RELIGION in Virginia, South Carolina, \&c. PARTICULARLY among the Negroes. London, 1761.

A small number of very valuable communications from Presbyterian preachers in Virginia to two gentlemen in London. A great desire for books on the part of the Negroes of Virginia is herein shown; also some account of the progress of the Gospel among the blacks. 
26. Davis, John. Travels of Four Years and a Half in the United States of America during 1798, 1799, 1800, 1801, and 1802. London, 1803. Reprint N. Y. 1909.

One of the very best books of travel. Davis was a writer of some note and his eye eagerly caught the picturesque things. His style guarantees easy reading. He taught school for a short while in Virginia and his trained mind soon saw the things of interest. He did not write about a large area in Virginia, but his work was done well.

27. Dowd, Jerome. The Negro Races. A Sociological Study. N. Y. 1907.

This study is a detailed one of three African races. The matters covered by the term "A Sociological Study" are quite broad and varied. The family affairs there, being so different from ours, are matters of especial interest. Such keen anal$y$ ses as the author gives of conditions serve to put knowledge ahead of surmise.

28. Drewry, W. S. Slave Insurrections in Virginia. Washington, 1900.

The main body of the book deals with the Southampton Insurrection. The author knew the country well, walked over the ground. photographed places described in his narrative and gives a thoroughly readable account of the plot and participants. He does not attempt to do much with the consequences of the outbreak.

29. Du Bois, IV. E. Burghardt. The Philadelphia Negro. Phil. 1899.

One of the finest local studies. Du Bois was working under the auspices of the University of Pennsylvania and did his work thoroughly. His schedule of questions for investigation into home conditions are especially interesting. The conclusions are logical and fair and the whole work a compliment to its author.

30. Du Bois, W. E. Burghardt. The Souls of Black Folk. Chicago, 1909.

This book is frightfully pessimistic in tone. The style is wonderful; the language beautiful. No one can read these es- 
says without feeling the situation of the Negro. Facts of history are not accurately stated but perhaps the author sacrificed history for the music of his words.

31. Du Chaillu, Paul. Explorations and Adventures in Equatorial Africa. New York, 1868.

$\mathrm{Du}$ Chaillu's expeditions are replete with stirring incidents. The ideas of the natives, their general untrustworthiness, the - fidelity of some, their hospitality or lack of it, their modes of living and ceremonies at their burials are narrated. It is not considered such a valuable work as some of the later exploration trips.

32. Edmundson, William. Life, Journey, Suffering, etc., of. London, 1774.

The life of this pioneer Quaker shows him to be an intrepid character. His journeys were many and long, and his sufferings intense. The work is interesting to those who are studying religious pioneers and the causes they championed. Edmundson did much for the Negro.

33. Ellis, A. B. The Tshi-Speaking Peoples of the Gold Coast of West Africa. London, 1887.

34. the Slave Coast of West Africa. London, 1890.

35. The Yoruba-Speaking Peoples of the Slave Coast of West Africa. London, 1894.

36. Ellis, A. B. A History of the Gold Coast of West Africa. London, 1895.

Accurate, discriminating, detailed accounts of the peoples described. Ellis knows the land and the people. His account of their religious lives opened up to us many of the secrets which we could not have understood without his help.

37. Evans, Joshua. A Journal of the Life, Travels, Religious Experiences and Labors in the Work of the Ministry. Philadelphia, 1837.

A good Quaker who served faithfully. He spoke in opposition to slavery in Virginia. His life was little different from that of the other pioneers. 
38. Fithian, Philip Vickers. Journal and Letters 1767-1774. Tutor at Nomini Hall in Virginia 1773-74. Edited by John Rogers Williams. Princeton, 1900.

One of the most reliable accounts of things as they. were in Virginia. The Presbyterian theologue is enchanted by the gaities of Westmoreland county life, yet feels that he must not give himself over to them. His opinions were anti-slavery and it is almost sure that the chatelaine of Nomini Hall shared his ideas on that subject. He points out many interesting things about the life of this colony that are not made clear elsewhere. His work was well done and deserves the high place usually given it because of its intimate view and manifest honesty.

39. Fleming. W. L. Civil War and Reconstruction in Alabama. New York, 1905.

The author of this splendid work is recognized as one of the foremost authorities on Reconstruction. His view is an intimate one and his knowledge of details very useful in shedding new lights on a difficult period. The work is written in great fairness and is one of the valuable contributions to history in recent years.

40. Foote. Wm. Henry. Sketches of Virginia, Historical and Biographical. Second Series. Philadelphia, 1855.

The Sketches by the Presbyterian Foote are among the most important sources of Virginia history. There is a mass of material in them concerning prominent men who made Virginia what it is. He relates many minor details, and because of his wide interests, the Negroes found a place in his work. No one would think of working in Virginia history without consulting Foote.

41. Force. Peter. Tracts and Other Papers, Relating Principally to the Origin, Settlement and Progress of the Colonies in North America. 4 vols. Washington, 1836, 1838; 1844, 1846.

This collection of old materials is contained in four volumes published separately per dates above. Virginia has a prominent place in any good work dealing with all the colonies and Force's Tracts are not exceptions. Maryland also finds a prominent 
place. The part dealing with Virginia gives such papers as Virginia's Cure, Leah and Rachel and others. It is mostlyeconomic in its scope.

42. Friends, Discipline of the Yearly Meeting of, Held in Baltimore. Printed by direction of the meeting held in the year 1806. A revision 1821. Baltimore.

The Yearly Meeting was the governing body of the Friends in a district covered by such meeting. The Discipline is the body of Church laws governing the Quakers.

43. Godwyn, Morgan. The Negro's and Indians Advocate. Suing for their Admission into the Church. London, 1680.

44.

A Supplement to the Negroes and Indians Advocate; or, Some further Considerations and proposals for the effectual and speedy carrying on of the Negro's Christianity in our Plantations (notwithstanding the late pretended Impossibilities) without any prejudice to their Owners. London, 1681.

These pamphlets are very valuable as illustrations of the views of some writers concerning the Negro question during the 17th century. The papers also show something of the religious life of the times. The writer was a Virginia parson. must have known his subject matter from his own observations. and wrote in an academic style.

45. Goodell, William. The American Slave Code in Theory and Practice: Its distinctive features shown by its statutes, $\mathrm{ju}$ dicial decisions, and illustrative facts. New York, 1853.

The viewpoint of this book is that of opposition to slavery: A Negro who reads this book would note the many unfortunate conditions entailed by slavery without finding any of the compensating features of slavery mentioned. It is not an impartial statement of the case, but is a brief for the plaintiff without any consideration of the defendant's position.

46. Harrison and Barnes. The Gospel among the Slaves. At Short Account of Missionary Operations among the Slaves of the Southern States. Nashville, Tenn., 1893.

The title tells just what the book does. The sources of this book were often originals and all the matter that went into it 
was carefully weighed. It keeps chronology in view while stating the subject matter forcefully.

47. Haygood. Atticus, G. Our Brother in Black. 1881.

Our Brother in Black has become an expression frequently on the lips of those favoring some adjustment of the Negro question which gives the Negro a chance. The address by Bishop Haygood gave the title currency and his insistent urging that white men share the burdens borne by the blacks has not been in vain. The above is filled with sane, sound advice to whites and blacks.

48. Hotten, John Camden. Original Lists of Emigrants to the American Plantations 1600-1700. From MSS. Preserved in the State Paper Dept. of Her Majesty's Public Record Office, England. N. Y. 1874.

The knowledge of the numbers of the first settlers can be verified by consulting this work. The work gives the musters of the plantations which showed the number of Negroes present in the colonies in 1674-5. This book is especially valuable because of that census.

49. Howison, R. R. A History of Virginia from its Discovery and Settlement by Europeans to the Present Time. 2 vols. Richm'd. 1848.

These volumes are interesting and were written by a man of sound learning. His style of composition, however, was that in vogue before the war, viz. the discursive. Judged by the historical canons of the present, the work is found wanting in places. In olden days writers of history too frequently wrote down what they heard without carefully testing the truth of the statements recorded.

50. Jackson, Mary Anna. - Life of General Thomas J. Jackson. N. Y. 1891.

An account of the life of a man such as his wife would be expected to write. It gives many intimate ideas of Jackson's home life. It does not pretend to be a military biography. Very valuable for our purposes. 
51. Jefferson, Thomas. Works. Memorial Edition. Washington, 1903.

The contributions of this prominent American to the history of our country make his writings especially valuable. His advanced views concerning the Negro were considered radical. His large acquaintance with men and things and his versatility make his writings seem something like a source book. 1724

52. Jones, Hugh. The Present State of Virginia. London,

A very rare book which deals with economics in early Virginia history. The descriptions deal in part with the religious welfare of the Colonists but mainly with matters which make for present existence.

53. Kennard, Richard. History of the Gilfield Baptist Church of Petersburg, Va.

The Negro Church described above has had a very long history. The clerk of the church searched the old records and talked with old members until he gathered the materials. His book has no surprising features, but is a plain, unvarnished narrative of happenings in that religious body.

54. Kingsley, Mary. Travels in West Africa. London, 1897.

55. ——. West African Studies. London, 1899.

Written in attractive style, one would hardly have to guess that these books were written by a woman. Miss Kingsley is an English lady and her contact with African life in Africa is charmingly embodied in her books. She writes things as she sees them; not as other books see them.

56. Lee, Elizabeth. Virginia: Past and Present.

Little other than a sketch of a good minister and some suggestions for helping the Negroes by taking a personal interest in them. The pamphlet is entertainingly written.

57. Leigh, Benjamin Watkins. Virginia Slavery Debate. Rich. 1832.

Nine speeches and the Letter of Appomattox to the people of Virginia are contained in this volume. The future of slavery in 
Virginia was hanging in the balance while the great debate of 1831-2 raged. This volume contains some of the best speeches and an able letter.

58. Lyell, Charles. F. R. S. Travels in the United States -Second Visit. 2 vols. New York, 1868.

The observations of a distinguished English gentleman. Geology finds much space in his description. . Some interesting accounts of persons as Englishmen saw them through the glasses of assumed superiority.

59. McConnell. John Preston. Negroes and Their Treatment in Virginia from 1865 to 1867 . Pulaski, Va., 1910.

This splendid intensive study is based largely on Newspaper accounts during the period described. Dr. McConnell brings order out of the chaos of misinformation connected with that time. His directness of attack and clearness of statement cause his points to be concise and well-understood.

60. McGuire. Judith W. Diary of a Southern Refugee during the War. New York, 1867. Richmond, Va. 1889.

Mrs. McGuire had no idea that this diary would ever be published. She was a Southern lady who wrote perfectly naturally during the War and later resolved to allow her writings to be published. Sorrow is expressed at Southern defeats, joy at their victories: the attempt of the people left at home to carry on things as they were left, is shown.

61. McTyeire, H. N. History of Methodism: comprising a View of the Rise of this Revival of Spiritual Religion in the First Half of the Eighteenth Century and of the Principal Agents by whom it was Promoted in Europe and America; with some account of the Doctrine and Policy of Episcopal Methodism in the United States, and the means and manner of the Extension down to A. D. 1884. Nashville, Tenn., 1884.

- A Southern account of the split in the Methodist Church. Incidentally the emphasis is laid on work for Negroes whenever the opportunity affords. A valuable church history by a scholarly writer and a distinguished man. 
62. Meade, William. Old Churches, Ministers and Families of Virginia. 2 vols. Philadelphia, 1861.

The knowledge of persons and events which Bishop Meade had mastered demanded that his works be highly esteemed. He was mature when the great slavery adjustment measures of 1831-2 were being discussed. and his frequent conversations with people of many sorts in different parts of this Commonwealth gave him excellent opportunities to know public opinion. His work is invaluable for genealogists, church historians and students of the relationships between church and state. These books are ecclesiastical histories in fact. The Bishop was almost a Puritan, and his strictures were perhaps harsher than any arguments that the opponents of the church brought. His comments on the Negro are few in number, but illustrate some important phases of the question.

63. ——. Sketches of Old Virginia Family Servants. Phil. 1847.

This interesting volume was written by a granddaughter of General Thomas Nelson, and edited by Bishop Meade. The fine old Negroes described so vividly in this book serve to keep alive the memory of a species soon destined to become extinct. The author is intimately acquainted with the characters described. Many of the finer relationships between masters and servants are here narrated.

64. Mitchell, Joseph. Missionary Pioneer-Memoir of John Stewart. New York, 1827.

The narrative of a Virginia Negro who left this State and eventually worked as missionary among the Indians in (Ohio. No startling tales, but an account of a good life and its beneficial influences.

65. Montgomery Conference. Proceedings of 1900.

A great body of distinguished Southerners gathered at Montgomery to discuss the Negro question from an unprejudiced, scholarly view-point. Fine suggestions were given and some knotty problems raised for discussion. The papers delivered are thoughtful and cannot be overlooked by students of the Negro question. 
66. Moorland. Jesse E. The Demand and the Supply of Increased Efficiency in the Negro Ministry. In American Negro Academy Papers No. 13.

A very timely pamphlet on a very important subject. The remedies for present evils in the Negro ministry are suggesterl. The article was not intended to be historical. It is filled with the kind of suggestions that will solve many of the Negro's religious problems.

67. Munford, B. B. Virginia's Attitude toward Slavery and Secession. New York, 1909.

A long-looked for book. The world had heard only one sirle of the story and Col. Munford told the other. The world heard his story, too. The author's preparation for his work was adequate to every need. As a man prominent in Virginia affairs he proves the kindly interest of former prominent Virginians in their slaves. Col. Munford has a thesis to prove and overlooks the immorality curse of slavery. His book abounds in citations.

68. Murphy, Edgar Gardner. The present South. A discussion of certain of the educational, industrial, and political issues in the Southern States. New York, 1904.

No man has written with larger vision concerning the Negro than Edgar Gardner Murphy. His luminous sentences and clear thinking impress all who read his books. Mr. Murphy's interests were cosmopolitan. Perhaps his book is the best on the problem which has yet appeared.

69. Odum. Howard W. Social and Mental Traits of the Negro. N. Y. 1910.

We would put few books on a level with this as a statement of things as they are among Negroes in the South. The author writes interestingly and gives more details than the ordinary writer gives facts. For a knowledge of actual conditions among the middle and lower masses this book has no equal. It gives scant acknowledgment to the better class of Negroes.

70. Olmsted, Frederick Law. A Journey in the Seaboard Slave States. New York, 1863.

One of the best known books on conditions in the South prior to the War. Unfortunately the author was a bit biased. Cer- 
tainly he was not so biased as some other travellers, but his lias was all the more regrettable because of his supposed fairness. His eye saw everything it seemed. His minute account of the conditions among Negroes is very valuable except for the slight bias.

71. Page, Thomas Nelson. The Old Dominion. Plantation Edition. New York, 1909.

A thoroughly interesting collection of essays dealing with features of life under the old regime. Dr. Page is perfectly at home when writing on this subject. In none of his other works does he appear so intensely a Virginian and an upholder of Virginia's place in history. The style is that so widely known graceful expression characteristic of the author's works. This book is social history.

72. Page, Thomas Nelson. The Negro the Southerner's Problem. New York, 1904.

Dr. Page has had experiences with a splendid type of Negro in the times when many of the ante-bellum Negroes were the warm friends of their masters. In later years his point of contact has almost entirely disappeared and he in all probability saw intimately only the trifling domestics and laborers. He eulogizes the old-time Negro, sees little good in the presentday Negro and perhaps is unjustified in some of his prophecies which indicate a distrust in the future of the Negro. This book is charmingly written and will fit the views of all men acquainted with the better features of the old regime.

73. Parsons, C. G. Inside View of Slavery. 1855.

This book presents a one-sided view of slavery conditions as seen by a man who was looking for flaws. No one could deny that glaring defects stood out in the system of slavery, yet it is unfair to present only one side of the matter. This book is anti-slavery.

74. Perry, Wm. Stevens. Historical Collections Relating to the American Colonial Church-Virginia. Privately printed. 1870.

Many historical documents are found here that are not found in other books. Dealings with the Bishop of London which 
are especially valuable are found here and these throw interesting lights on the early religious situation in Virginia. The correspondence with the Bishop and a few other documents deal with the Negro on his religious side. The value of this. work can hardly be overestimated.

75. Pollard, E. A. Black Diamonds ; gathered in the darkey homes of the South. New York, 1859.

A book of letters supposed to have been written to a friend in the North. It is a thoroughly Southern view. The letters are well-written and give light on the problem of the health and housing of the Negro. The religious references note only the best old-time darkeys.

76. Pulszky, Francis and Theresa. White, Red, BlackSketches of American Society in the United States during the Visit of their Guests. New York, 1853.

A book of travels. We know of no distinction which it could possibly claim. Its references to the Negro are meagre. but worthy of notice. Few foreigners understood the slavery question as it existed in Virginia and these follow the rest in their prepossessions.

77. Quaker Pamphlets. In Park Avenue Meeting House Library, Baltimore, Md.

A miscellaneous collection of pamphlets dealing with events in which the Quakers were prominent participants. A few deal with the Missionary activities among the Negroes after the War.

78. Religion: A Narrative of the Revival of in Virginia: London, 1779.

This book contains letters and especially the long letter of Rev. Devereux Jarratt on the above subject. It shows that Rev. Mr. Jarratt was a friend to the Methodists and gives an intimate account of the great religious awakening of 1776, as noted by one who was a chief participant. We learn from this volume that the Negro was by no means entirely neglected in those days. 
79. Rochefoucault. Duke de la Liancourt. Travels Through the United States of North America, Canada, etc., in the Years 1795, 1796 and 1797. 4 vols. London, 1800.

The observations of a famous Frenchman in America. He is of the Nobility and finds many things disappointing in our country. His four large volumes cover many features of our national existence. He touches the Negro question more on the economic side than on any other. These books of travels are standard.

80. Royall, Wm. L. History of Virginia's Debt Controversy, or The Negro's vicious influence in politics. Richmond, 1897.

The writer was a lawyer and took an active part in the events he describes. He was a man of strong prejudices, and Mahone and the Devil seemed to look alike in his eyes. Since the Negroes followed Mahone in such great numbers, we need not expect the Negroes to receive encomiums from him.

81. Russell. John. The Free Negro in Virginia. 1619-1865. Johns Hopkins University Studies. Series 31. Baltimore, 1913.

Perhaps the most interesting dissertation in years. Dr. Russell, although a young man, wrote with a sureness of touch characteristic of an older writer. He has shown complete mastery of his subject. has divided his book into suitable divisions and has contributed much to Virginia history. His knowledge of his sources was profound and his citations timely and appropriate. Indispensable to a full understanding of the Negro problem before the war. Accurate and worthy of a much fuller comment.

82. Schoepf, Johann David. Travels in the Confederation. Translated and edited by Alfred J. Morrison. Philadelphia. 1911.

The Schoepf Travels rank high among that type of literature. The affected superiority of some observers and their superficiality are notably absent from this book. His work was done long ago, but its spirit was that of a modern investigator. 
83. Semple, R. B. A History of the Rise and Progress of the Baptists in Virginia. Richmond. 1810.

A. splendid book written by a reliable writer. Semple was not perfect. yet he had a fine historical eye for a man of his time. Much of the material in Semple has no counterpart elsewhere and we are compelled to rely on him, or throw away such facts. His work is much used as a source.

84. Slaughter, Philip. Virginia History of Colonization. Rich. 1855.

The Colonization Society work was looked to as a possible relief from the evils of the slavery system. Bushrod Washington. Bishop Meade, and other prominent men gave of their time and money in order that the free Negroes of Virginia might be given a home in Africa. The Negroes did not want to go and the Society did not fulfill the designs of its incorporators. Rev. Mr. Slaughter's work gives an insight into the high motives which inspired the Virginians to endeavor to solve the race problem by colonization.

85. Smedes, Susan Dabney. Memorials of a Southern Planter, Baltimore. 1888.

The life of a notable Southern gentleman is here described. Few characters show many points of superiority over that of Col. Thomas Dabney. His high motives, consideration for others and care to do his duty and even more, mark him as a fine type of manhood. The slaves under the best masters find representation in this book. It does not deal with the evils of slavery because they were not present on the plantation that the author describes.

86. Stanley, H. M. Through the Dark Continent. 2 vols. N. Y. 1878.

The thrilling dash of Stanley into the Jungles of Africa to find Livingstone on a commission from James Gordon Bennett of the New York Herald is still fresh in the minds of older people. Stanley went a long distance and wrote out his observations. His work has never received the acceptance accorded some of the more painstaking studies of African life. 
87. Taylor, Jas. B. Lives of Virginia Baptist Ministers. Rich. 1837.

A book of biographies of prominent Baptist preachers. Serviceable to us because of the large space devoted to the Negro Missionary, Lott Carey. This gives an insight into religious conditions of the first third of the Nineteenth and part of the Eighteenth.

88. Thomas, Wm. Hannibal. The American Negro. New York, 1901.

The Negro Thomas is radical. He cuts and slashes his own race without just provocation at times. He has an intimate knowledge of the slum Negroes and presents that without regard for the better type of Negro. We strongly suspect that he expected to curry favor with the whites by conceding so much to the detriment of his race. His broad-mindedness becomes historical laxness.

89. Tillinghast, Joseph Alexander. The Negro in Africa and America. Publication of Am. Economic Association. 3d. Series, vol. III. No. 2. New York, 1902.

The painstaking work done on the above book gives some idea of the seriousness with which the Negro problem is now attacked. This work is rather pessimistic concerning the future of the Negro and recounts most of the discouraging things of his past. The author credits the Negro with little capacity to ever do much. The work expresses the sentiments of the great majority of white people, we believe.

90. Tupper, H. A., Editor. The First Century of the First Baptist Church of Richmond, Virginia. Richmond, 1880.

A number of the more eminent members of the First Baptist Church presented some very valuable papers at the Centennial of that Church. The papers were embodied in a book. Many historical facts may be gleaned from this volume. It is one of the best church histories published in Virginia.

91. Washington, Booker, T. The Future of the American Negro. Boston, 1899.

A typical Washington book. He sees a roseate future for. 
the Negro by the pathway paved with golden dollars. He tells many interesting incidents, and sustains the attention of the reader. His predictions are not radical and ideas of racial amalgamation he wisely leaves unmentioned.

92. Washington, Booker T. Up from Slavery. New York, 1901.

This autobiography is a volume which gives an insight into the life of the leading Afro-American in this country. Booker Washington is a Virginia-born Negro and his useful career has demonstrated that he has a marked talent for leadership. This book is eagerly sought by the oppressed all over the world and has proved an inspiration to many. The knowledge of Negro life and conditions and the broad-minded way of dealing with them commends such a work to the student of the latter half of the Nineteenth Century.

93. Washington, Booker T. and W. E. Burghardt Du Bois. "The Negro in the South. his economic progress in relation to his moral and religious development; being the William Levi Bull lectures for 1907:" Philadelphia, 1907.

These lectures are well worded and show the contrast between Washington and Du Bois. Washington is conservative, shrewd, an allayer of racial discord and an advocate of manual labor; $\mathrm{Du}$ Bois is radical, brilliant, an insister on rights and recognition, and one of the staunchest supporters of the booktrained Negro. Both see the absolute need of better economics in the lives of Negroes and both ardently advocate property ownership for its moral value as well as for its economic.

94. Weatherford, W. D. Negro life in the South. New York, 1911.

Dr. Weatherford's book did more to stir college men to the importance of the Negro question than any other single volume. He writes burning words and really feels that he has a great task to perform in presenting his ideas. He writes entertainingly and covers the whole question in his book. Of course, none of his work can be carried as far as a scholar would desire because of a lack of space. His great work was 
to stir others to study the problem. His book is a valuable addition to the volumes published on the subject.

95. Weld, Theodore D. American Slavery as It Is; Testimony of a Thousand Witnesses. New York, 1839.

Perhaps the most radical indictment of slavery. The book was published by the American Anti-Slavery Society and many expatriated Southerners contributed the most radical stories of atrocities imaginable. Insane men were always in the South, but it is a mark of insanity to think that all people here were insane. The treatment of Negroes as stated in this book was the exception and not the rule. The book is not to be taken seriously.

96. Wheatley, Phyllis. Her Poems.

An excellent little volume of poems by a Negro girl who was a slave in Massachusetts and later was freed by her master. The work cannot approach the excellence of the poetry written by Paul Lawrence Dunbar, yet it is wonderful poetry for a Negro slave of the Eighteenth Century.

97. White, William S. The African Preacher-an Authentic Narrative. Philadelphia, 1849.

The Ante-Bellum Negro at his best is here represented. No one can read this profound statement of the homely virtues of a good man without feeling that slavery had its good features as well as bad. It is a personal narrative, written with full knowledge of the character described.

98. White, William S. William S. White, D. D. and His Times-An Autobiography. Edited by his son, H. M. White. Richmond, Va. 1891.

A man of great power in the Presbyterian ministry gives some of the important events with which he was acquainted. Rev. Mr. White was pastor of the church in Lexington that "Stonewall" Jackson attended and he was a leader in work for Negroes. A valuable autobiography.

99. Williams, Geo. W. History of the Negro Race in America. New York, 1882.

The Negro who wrote this book covered a tremendous field 
and it need cause no surprise that he allowed inaccuracies to creep in, and omitted much. The surprise is that he covered the field so well. The writer is a talented representative of his race and has done a great work for his race. He overjools much of the good of slavery for the sake of blaming its wrongs. His history is suggestive of better work for the future on the same subject. Its spirit is modern.

100. Woolman, John. Life and Travels of. Philadelphia, 1774.

The lives of the pioneers require little comment. They are romantic enough to thrill one and dramatic enough to prove that the roles they acted required masters. The autobiography of this Friend is one of the volumes relied on for occasional insights into the Negro's condition during the 18th Century. 


\section{APPENDIX.}

The personal element is an especially important one in the discussion of the religious phase of the Negro question in Virginia. An institution is largely interpreted by its human exponents. The Negro church is largely measured by its members, but it must also be measured by its leaders. The Negro ministers of Virginia are excellent men in many instances and this history could not be complete without some specific references to the lives and work of these. The evils which the Negro race is heir to and which environment has superposed upon it are largely to be met by the forces marshaled by these religious leaders. If the influence of the Negro preachers is waning at all, it has not yet waned so perceptibly as to hamper seriously the good work which they endeavor to do. No one can deny that many of them are factors for good.

The names of some of the more prominent Negro ministers of Virginia are appended. Some of these men are doing the real constructive work by which the Negro Church is to be judged. We could not attempt to make the list inclusive, but we have endeavored to present the lives of some of the foremost among their religious leaders. Many very young men will find their names omitted. but if their work of the future in the ministry is commensurate with their promise at present, some later writer will be pleased to record their worthy achievements.

In securing this data we were greatly aided by a few leaders among the leaders of Negroes. In this appendix the ministers' names are arranged alphabetically under the various ecclesiastical divisions. When the lists were prepared, the following letter was sent to each person whose brief biography is here given, and the responses were prompt and given with a seeming desire to aid in the study of the question:

You have been designated to me as one of the most prominent preachers of your denomination in Virginia. I am now writing a "History of the Religious Development of the Negro in Virginia," and I want to include your biography as one of 
the present-day leaders in the racial uplift. Please answer the questions below immediately (it will only require a few minutes time), and return to me in enclosed stamped envelope. This matter is pressing and very important.

1. Full name:

2. Date and place of birth:

3. Titles (such as B. D., LL. D., or Ph. D.) : D. D.

4. Education-Name of institutions and date of courses:

5. If married-Date of and to whom:

6. Give names of churches, locations and length of your different pastorates:

7. Number of members in your present church:

8. How long have you been preaching?

9. Any public honors-Political, fraternal or otherwise?

10. Any interesting facts concerning yourself that you consider important?

\section{Convention Baptist.}

1. Full name: W. R. Ashburn.

2. Date and place of birth: Feb. 8.

3. Titles (such as B. D., LL. D., or Ph. D.) : D. D.

4. Education-Name of institutions and date of courses: Va. Theo. Sem. \& Coll.

5. If married-Date of and to whom: Josie Campbell, July, 1893, and M. C. Holmes, June, 1898. both deceased.

6. Give names of churches, locations and length of your different pastorates: First Baptist Church, Salem. Zion Baptist, So. Richmond, Cool Spring Baptist Church, Franklin, Va. Cool Spring is the present charge, have been here 7 years, and at the others 3 and 7 each.

7. Number of members in your present church: 900 .

8. How long have you been preaching? 20 years.

9. Any public honors-Political, fraternal or otherwise? Was State Missionary for the Va. Baptist State Convention. Am president of the State B. Y. P. U. of Virginia.

10. Any interesting facts concerning yourself that you consider important? Mother and father both living, with 8 children; 
2 sons pastors, a son and daughter physicians; the president of the Ashburn Brothers Shirt Mfg. Co.

1. John Hilyer Ashby.

2. June 10, 1875, York Co., Va.

3.

4. I received my education under private teachers, much of the time I was my own teacher.

5. Fannie S. Scott of Powhatan Co., April 10, 1900.

6. First Baptist, Williamsburg, Va., 3 years, Shiloh Baptist, Norfolk, 5 years, and am still in charge.

7. 300 .

8. Nine years.

9. Member of State Board of the Va. Baptist Convention and is mentioned as successor to the late Dr. R. H. Bowling of Bute Street Baptist Church of Norfolk.

10. Without even a Normal School education or the supporting influence of any special person, the Lord is using me with great success.

1. Junius Caesar Austin.

2. Aug. 1, 1885, New Canton, Va.

3. B. D., D. D.

4. Virginia Seminary and College, Lynchburg, Va. Spent eight years in this school, doing literary and theological work, from 1902-1910, graduating May 28.

5. Inez K. Pollard of Covington, Va., a tailoress. Nov. 23, 1910.

6. Main St. Baptist Church, Clifton Forge, Va., from June, 1910, to February, 1912. From that date to this hour, pastor of "The Mt. Zion Baptist Church," Staunton, Va.

7. 1342 .

8. 14 years. Held a summer charge while in school in Belmar, N. J., from 1906 to 1909.

9. On graduating I was class orator; and in the Annual Oratorical Contest I won the Gold Medal.

10. Within these two years we have added unto the church 342 souls and raised over $\$ 11,000$. Was converted when 11 years old, licensed to preach at the age of 14 years. 
1. Richard Wright Ashburn.

2. April 15, 1876, Churchland, Va.

3. B. D.

4. Public Schools, Norfolk Co., and Va. Theo. Sem. and Col., Lynchburg, Va. Pub. School from 1883 to 94 . College from ' 97 to 1904. 4 years Academy, 3 years Theology.

5. Irene Baylor, Washington, D. C., Dec. 20, 1905.

6. Poplar Lawn, Wellville, Va., 2 years; Shiloh Baptist., Blackstone, Va., 10 years.

7. 750 .

8. 14 years.

9. Member Foreign Mission and Publication Boards, Va. Bapt. Convention. Ex-Treasurer State B. Y. P. U.

10. He finished school through hardship.

1. Samuel A. Brown.

2. Feb. 27,1876 , Charles City Co., Va.

3. B. A.

4. State Normal and Collegiate Institute. Normal Course 1895-98; Collegiate Course 1898-1902. Owing to lack of means-read Theology privately.

5. Clementine Poole, Sept., 1903.

6. Second New Hope Bapt., Spottsylvania Co., Va. 4 years . . . Gillfield Bapt. 1 year.

7. 1500 .

8. 14 years.

9. For six years have been president of one of the largest associations in the state-viz., Mattaponi Bapt. Assoc.

10. Worked my way up from the bottom with no one to contribute a cent to my education. Am president of a colored High School at Fredericksburg, Va., which I founded in 1905. We now own property worth $\$ 7,000$, including 25 acres land for demonstration work.

1. James Hampton Burks.

2. Boonsboro, Bedford Co., Va., Dec. 7, 1873.

3. B. D. 
4. Virginia Theo. Seminary and College. Jan. 2. 1892-June, 1900.

5. Rosa Davis, Lynchburg, Va., Jan. 2, 1902.

6. Zion Bapt. Church, Manchester, Va. 2 years: High St. Bapt. Church, Roanoke, Va., from Sept., 1902, to present time 7. 1,000 .

8. Since July, 1900.

9. Degree of D. D. conferred upon me by my Alma Mater in 1912.

10. Chairman of Trustee Board of Va. Theological Seminary and College; Moderator of Valley Bapt. Association.

1. J. G. St. Clair Drake.

2. March 5, 1879, Payne's Bay, St. James, Barbados, British West Indies.

3. B. D., D. D.

4. Graduated from Academic Department of Harrison College, Bridgetown, Barbados, British West Indies, June 28, 1899. From Va. Theo. Seminary \& College, Lynchburg, Va. (College and Theological Courses), with degree B. D. May 27, 1907. Doctor of Divinity from Afro-American School of Correspondence, Washington, D. C., Sept. 25, 1913.

5. Bessie L. Bowles, Staunton, Va., April 6, 1910.

6. Antioch Baptist Church, Peaksville, Va., 1905 to 1907 (while in College). . . . . First Baptist Church, Harrisonburg, Va., present charge, Jan. 1, 1913.

7. 300 .

8. From 1902 to present.

9. I was elected Statistical Secretary of Virginia Baptist State Convention at its meeting in Newport News, Va., May, 1908 , and hold that position until now.

10. During my summer vacation while in Va. Theo. Sem. \& College I travelled as Financial Secretary for the Baptist State Sunday-school Convention of Virginia, with much success to the work. Spent two years in Paris, France, studying French language. Organized and was president of Nansemond Normal and Ind. Inst., Suffolk, Va., until throat affection compelled me to resign. From 1907 to 1908. 
1. Alexander Arthur Galvin.

2. New Glasgow, Amherst Co., Va.

3. B. D., D. D.

4. I am a graduate of Va. Theological Seminary and College, having completed the Academic and Theological Courses, May, 1897.

5. Janie P. Toles, Dec. 22, 1897.

6. I pastored Ebenezer Bapt. Church, Staunton, Va., four years and a half, and this coming June will make twelve years for me in the Loyal St. Bapt. Ch., Danville, Va.

7. About 1,000 .

8. Sixteen years.

9. I am a trustee of the above named school and Pres. of the Va. Bapt. State Convention.

10.

1. Louis R. W. Johnson.

2. Dec. 11, 1878, Staunton, Va.

3. A. B., A. M., S. T. B.

4. Lincoln Uni. Pa. College and Theo. Sem. 1895-'99-College, 1899-1902-Theology. With summer and Correspondence Courses since at several institutions.

5. Alberta B. Coles, Charlottesville, Jan. 4, 1904.

6. Mt. Zion Bapt. Church, Millboro, 1903-04. . . . . Now at Va. Theo. Sem. \& College, and Church.

7. Not less than 1500 .

8. Since 1902.

9. None.

10. Instructor of Freshmen and Sophs. in Greek at Lincoln Uni. (while a theological student). Principal of Piedmont Institute Charlottesville (burned 1905). Dean of Theo. Dept. and Prof. of Greek, Va. Theo. Sem. \& College, Lynchburg, Va. 1907-8, during which Deanship I was called to Court St. Bapt. Church. This space of 12 years has been well used both in preaching and teaching.

1. Charles E. Jones.

2. Concord, Campbell Co., Va., July 31, 1877. 
3. B. D.

4. Va. Theo. Sem. \& College, Lynchburg, Va., May, 1901, finished.

5. April 22, 1903, Alice A. Walker Harris.

6. Zion Baptist Church, Newport News, Va., 13 years.

7. 500 .

8. 14 years.

9. Only Pastor.

10. In 1910 the Holy Ghost used me remarkably in that 337 souls were converted unto God in Zion Baptist Church. Now building a church to cost $\$ 25,000$.

1. Samuel Alford Moses.

2. Charlotte C. H., Mar. 17, 1877.

3. A. B., D. D.

4. Virginia Theo. Sem. \& College, Lynchburg, Va. College, '05, Theology, '05.

5. June 10, 1908, Carrie L. Calloway, Richmond, Va.

6. General Supt. Missions, Va. Bapt. State Convention, 1905-08; First Bapt. Church, Harrisonburg, Va., 6 years; High St. Baptist Church, Danville, Va., 1 year.

7. 500 .

8. 15 years.

9. No.

10. I am one of three brothers who are pastoring. The other two are: Jas. M. Moses. D. D., pastor of Monumental Bapt. Church. Phila.; and W. H. Moses, D. D., pastor of Mt. Zion Bapt. Church, Knoxville, Tenn.

1. Joseph Jordan Nickerson.

2. July 4, 1875, Jefferson Co., Florida.

3. Pursuing a B. Th. course.

4. Literary and Theological, 1907-1913. Virginia Union University, Richmond, Va.

5. June 28, 1907, Carrie E. Nichols.

6. St. John Baptist Church, Ormond, Florida, 1904-06. The first four years of my ministry were spent largely in mission work. Now in Williamsburg, Va. 
7. 800 .

8. 13 years.

9. None.

10. My life from childhood to manhood was spent in the country, where the chances for an education were poor, and I did not come in contact with men that could help me until I was twenty-eight.

1. Robert Cicero Pannell.

2. Leesville, Va., July 30, 1865.

3. D. D.

4. Public School, Campbell Co., and Lynchburg, Va., Hampton Inst. 5 years. Private course in Theology, 6 years.

5. Sept. 27, 1888, Maria Louise Branch, Lynchburg, Va.

6. Lovingston, Lynchburg, three years; Ebenezer Baptist Church, Staunton, eleven years.

7. 487.

8. Twenty-six years.

9. Pres. Western District S. S. Convention. Chairman Ministers Conference, Staunton. Moderator Berean Association at present time.

10. I am architect of the Ebenezer Church, begun in 1910, completed 1913, cost about $\$ 16,000$.

1. Charles Henry Phillips.

2. May, 1857, Louisa County, Va.

3. D. D.

4. None.

5. Dec. 31, 1903, Maggie Powell.

6. Union, Beaver Dam, 30 years; St. Thomas, Bumpass, 4 years.

7. 250 .

8. Thirty-five years.

9. I was endorsed as National Evangelist by the National Baptist Convention of America.

10. I have conducted revivals in at least twenty states, for twenty years, there have been fully 25,000 souls born into the kingdom of Christ. 
1. Lafayette F. Sharp.

2. Harrellsville, N. C., Jan. 14, 1873.

3. B. Th.

4. State Normal, Plymouth, N. C.: Roanoke Institute, Elizabeth City, N. C.

5. 1901, Lillie E. Cooper, Windsor. N. C.

6. Providence Bapt. Ch. Edenton, 6 years. . . . . first Baptist Church, Berkley, Va., 7 years.

7. 450 .

8. 18 years.

9.

10. Principal Albemarle Training School, Edenton, 4 years. Have been called to three large churches in North Carolina. Will leave for North Carolina, Apr. 15.

1. Thomas H. Shorts.

2. Fauquier Co., Va., Sept. 21, 1849.

3. D. D.

4. H. N. and A. I. Hampton, Va., and Guadalupe College, Seguin, Tex., 1889 and 1901, respectively.

5. Oct. 11, 1877, Cornelia Davis, Orange C. H., Va.

6. Garfield Bapt. Church, Clarke Co., Ta., 3 years. . . . . Queen St. Bapt. Church, Hampton, Va., 30 years.

7. 1,200 .

8. 35 years.

9. Fraternal P. S. G. R. of G. U. O. of G. F., also H. P. of same. V. C. of T. B. of Va. Sem. and College, Lynchburg, Va., Treas. State Board Bapt. S. Convention, Va.

10. Trying to complete our Queen St. Bapt. Church, Hampton, Va., destroyed by fire about eight years ago, at a cost of about $\$ 32,000$.

1. Jas. H. Smith.

2. March 6, 1861, Mathews Co., Va.

3. B. D., D. D.

4. Hampton Normal School. Theo. of Wayland Sem., 1888, Washington, D. C. Graduated at Storer College, 1890, and Howard University, May 27, 1892. 
5. Nov. 8, 1893, Susie A. Jackson, graduate Storer College.

6. New Mt. Zion, Gloucester Co., Va., 12 years . . . . first Bapt. East End, Newport News, present pastorate, 10 years.

7. 683 .

8. Began 1881.

9. Moderator Tidewater P. Bapt. Asso., first Vice Pres. Dis. S. S. Con. Trustee, Va., Theo. Sem. \& College, and of the Newport News Training School. Vice Pres. Whittier Memorial Hospital.

10.

1. Bernard Tyrrell.

2. Albemarle Co., near Earlysville, Va.

3. A. M., A. B., D. D.

4. Storer College, Harper's Ferry, W. Va., 1879. Hillsdale College, about 1883 to 1888 . Yale Divinity School, 1890 to 1893.

5. Sept. 12, 1894, Elizabeth Wilkerson.

6. Holcombe Rock Bapt. Church, Bedford Co., 15 months. The Diamond Hill Bapt. Church, Lynchburg, $181 / 2$ years.

7. 603.

8. Twenty-four years.

9. I have been Vice President from Va. of the National Baptist Convention six years. Vice President Va. Baptist State Convention.

10. Began teaching Greek, Latin, etc., in Va. Theo. Sem. \& College in 1893. Have been for a number of years and am now, Dean of Theological Department.

1. Robert Clisson Woods.

2. Nov. 17, 1882, Stewartsville, Va.

3. B. D., D. D., A. B., A. M.

4. Public High School. Va. Theo. Sem. \& College; College Course, A. B. 1906; Theo. Course, B. D. '06.

5. June 6, 1907, Octavia Hunter.

6. President Clayton-Williams University, Balto., Md. 1906- 
'08. First Baptist Church, Staunton, Va, 1908-'11. President Va. Theo. Sem. \& College, Lynchburg, Va., 1911.

7.

8. Eight years.

9. Have held prominent offices in State religious bodies.

10. Have written several pamphlets. The most widely read one, "Why I am a Baptist." A statement of the Baptists' position.

1. Thomas H. White.

2. Oct. 8, 1869, King and Queen Co., Va.

3. B. D., D. D.

4. Va. Theo. Sem. \& College, Lynchburg, Va., and private instruction. 4 years Academic and 3 years Theological Courses. 1890-97.

5. June 20, 1900. Martha A. Harper, Richmond, Va.

6. Asst. pastor First Baptist, Richmond, Va., 1897-'98. Instructor in Church Polity and Mathematics in my Alma Mater the sessions of 1898 and 1900 inclusive. . . . . First Baptist Church, Clifton Forge.

7. 400 .

8. Since 1894.

9. I am a 32 degree Mason and Grand Prelate of the $K$ of $P$. of Virginia. Cor. Sec. Va. Bapt. State Convention, and Virginia's representative on the Home Mission Board of National Baptist Convention.

10. Reared at Richmond, Va. Baptized into membership of First African Baptist Church, July, 1887.

1. Randolph W. Young.

2. 1851, Essex County.

3. D. D.

4. Richmond Theo. Sem. 1887-'89.

5. Feb., 1880, Mary C. Carter, Caroline County.

6. Mt. Tabor, Shumansville, Va., 12 years. . . . . Jerusalem, Car. Co., 9 years.

7. 1,100. (Three churches.)

8. About 35 years. 
9. President Essex Sunday-school Union and President of Caroline S. S. Union. Pres. of B. G. I. Academy and Trustee Board.

10. My pastorate in the above named churches has been one of peace and prosperity.

\section{Africax Methodist Episcopal Zion.}

1. James Parkhurst Foote.

2. Oct. 4. 1875, Iredelle Co., N. C.

3. A. B.

4. Completed Normal Collegiate courses at Livingstone College, Salisbury, North Carolina, 1902, 1906.

5. June 6, 1906. Berta Barksdale. June 8, 1910, Almeta Clinton.

6. Gethsemane, Charlotte, N. C., 2 years. . . . Oak St. Church, Petersburg.

7. About 350.

8. Since Nov., 1905.

9. None.

10. All of minor importance.

1. Beverly Joseph Bolding.

2. Feb. 7, 1866, Alexandria, Va.

3. A. B., B. D., D. D., LL. D.

4. Collegiate Howard University and Temple College. B. D. Episcopal Divinity School, 1890. Honorary Degrees from Lincoln and Livingstone College.

5. Dec. 24, 1890, Ella A. Drummond, Phila., Pr. of Inst. for Colored Youth.

6. Phila.. Pa. . . . . Oak St.. Petersburg, Va. Now · presiding Elder Petersburg District.

7.

8. 25. years.

9. Elected Editor Varick Endeavorer, May, 1900, a general office in A. M. A. Zion Church.

10. Built John Wesley A. M. E. Zion Church, Wash., D. C. Bought Pa. Ave. A. M. E. Zion Church, Baltimore, Md., and 
parsonage. Remodeled and bought other property to the amount of $\$ 65,000$ to A. M. E. Zion Church.

1. Elijah P. Mayo.

2. May 30, 1860 .

3. D. D., LI. D.

4. The Salem Academy, Salem, N. C., finished in 1887. Since then took a course in McKenley University.

5. July 10, 1902, Bessie C. Wilson, graduate of V. N. \& I. I., Petersburg, Va.

6. "The Old Ship" A. M. E. Zion church, Montgomery, Ala. $41 / 2$ years. . . . Am now pastor at Bristol, Va.

7. 275.

8. 22 years.

9. I was Grand Chief of the Co. of G. S. and D. S. in the state of Kentucky, while pastoring at Middleboro, Ky., for three years.

10. The people say I am a business man as well as a preacher. I own property in Tennessee and Virginia, Missouri, Kentuchy and Alabama.

1. Colson Willis Winfield.

2. Dec. 20, 1850, Dinwiddie Co., Va.

3. D. D., Livingstone College.

4. Kelly School and Payne Divinity School, 1878 to 1885 .

5. Dec. 11, 1872, Louisa Williams.

6. Oak St., Petersburg, Va., 4 years. . . . . P. E. 24 years.

7. 2,748 in my district.

8. 38 years.

9.

10. I have been Presiding Elder on the Edenton district 12 years, and on the Norfolk and Petersburg district 12 years.

1. Richard Hilton Riddick.

2. Tyrrell Co., N. C., in 1873.

3. A. M., D. D. 
4. Plymouth State Normal. A. M. from Eastern College, Newberne, N. C. D. D. from Livingston College, Salisbury, N. C. 5. June 11, 1902. M. E. Fox, Chillicothe, Ohio.

6. Varrick Chapel, Lunenburg Co., Va. . . . Norfolk.

7. 750 .

8. 15 years.

9. Grand lecturer for In. Order of Good Samaritans and Daughters of Samaria for State of North Carolina.

10. Was President of Edenton Industrial College for seven years.

\section{Association Baptists.}

1. Anthony Binga. Jr.

2. June 1, 1843. Amhersburg, Ontario, Canada.

3. D. D. from Shaw University.

4. King's Institute, Buxton, Ont.

5. Dec. 2, 1869, Rebecca L. Bush; 1909, M. V. Young.

6. Held principalship of Albany Enterprise Academy, Athens Co., Ohio, for three years and preached to students. Have been pastor of First Baptist Church So. Richmond 41 years and 9 months.

7. Over 1,400 .

8. Nearly 47 years.

9. Vice Chairman Trustee Board V. U. University ; Treasurer General Assoc. of Va.; Chairman Foreign Mission Board Gen. Assoc. Va.; Member Foreign Board Lott Carey Convention.

10. I was principal of Public School of this city for sixteen years. Have written and published eight pamphlets and books, one 324 pages.

1. George Washington Goode.

2. March 14, 1865, Patrick Co., Va.

3. B. D., D. D.

4. High School, Marion, Va.; Institute and Theological Courses in Richmond Theological Seminary completing the Hebrew and Greek Course with degree of B. D., 1895. Six years there. 
5. June 24, 1896, Mary L. Gaines, public school teacher of Richmond.

6. Salem Baptist, West Point, Va., 4 years, and Mt. Zion Baptist, Churchview, Va., at same time. Calvary Baptist, Danville, Va., 18 years.

7. About 550 . (It had 50 members when I came to it.)

8. About 28 years.

9. Secretary of Cherry Stone Association 14 years. President of Baptist General Association 7 years. Founder and President of Pittsylvania N. \& C. Inst. 12 years, etc.

10. Have not sought a position or work for 18 years. Have had lucrative positions on average of one every two years, since I've been here. Have given time and money to every phase of our denominational work. Specially interested in Foreign Missions. More than 1,200 have professed Christ since I came here.

1. Archie Allen Graham.

2. Feb. 9, 1873, Atlanta, Ga.

4. Knoxville College, Knoxville, Tenn., 1890-1895. Union Úniversity, Richmond, Va., 1898-1900.

5. Sept. 18, 1901, Florence E. Isham, Richmond, Va.

6. Zion Baptist Church, Phoebus, Va., 14 years.

7. About 1,600 .

8. About 15 years.

9. Moderator Norfolk Union Baptist Association. Secretary General Association of Virginia (col.). Ch'man Ex. Bd. Negro Organization Soc., Va.

10. Actively interested in questions of health and education of the race.

1. Royal B. Hardy.

2. March $2 \pi, 1856$, Botetourt Co., Va.

3. B. D.

4. Richmond Institute, Academic, 5 years. Theological Seminary, 3 years.

5. April 27, 1893, Feilisco W. Payne. 
6. Mt. Zion, Charlottesville, Va., 22 years at the same church. 7. 600 .

8. 27 years. (In school part of the time.)

9. D. D. was conferred by Va. Union University.

10. Moderator of Shiloh Baptist Association, which position I have held for 18 years.

1. William Thomas Johnson.

2. July 19, 1866, So. Richmond, Va.

3. B. D., D. D.

4. Virginia Union University, 1886-1893.

5. Sept. 5, 1895, Margaret R. Michie.

6. Mt. Olive Bapt. Church, Chesterfield Co., Va., 4 years First Bapt. Church, Lexington, Va., 9 years. First African Baptist Church, Richmond, 12 years.

7. 3,378.

8. 25 years.

9. Curator Hampton Normal and Industrial Institute; Trustee Va. Union University; Trustee United Society Christian Endeavor: Pres. Friends Orphan Asylum; Secretary Educational Board Gen. Assoc., Va.

10. I am also Treas. Negro Baptist Old Folks Home; Ch'man Lott Carey Foreign Mission Board of the Lott Carey Foreign Mission Convention.

1. Charles Henry Johnson.

2. Feb. 17, 1859, Culpeper Co., Va.

3. D. D. (from Va. Union University, Richmond, Va.).

4. Richmond Institute, completed Literary and Theological Courses May 11, 1883.

5. July 31,1889 , Winnie Lee Branch.

6. State Missionary Va. Baptist State S. S. Convention five years. Lee St. Bapt. Church, Bristol, Va. \& Tenn., 24 years.

7. 500 .

8. 35 years.

9. Moderator Schaffer Memorial Baptist Assoc. and VicePres. Bapt. General Assoc. Va., and State S. S. Convention 24 years. 
10. I received practically all my primary training from my parents' former owners, Rev. John Farrar and family of Lynchburg, later of Culpeper and Orange counties.

1. Joseph Eudon Jones.

2. Lynchburg, Va.

3. A. M., A. B., D. D.

4. Private training and three years private school in Lynchburg. Colver Institute. Graduated from the Academy and Madison (Colgate) University, 1876.

5. 1882, Rosa Daniel Kinckle, Lynchburg, Va.

6. Bethesda Baptist Church, Chesterfield Co., Va., 22 years.

7. 250.

8. 36 years.

9. Prof. in Richmond Inst. and Richmond Theological Seminary; now in Va. Union University.

10. Corresponding Secretary Bapt. For. Mission Convention, U. S. A. for a number of years. Also editor for years of denominational paper.

1. Zechariah Dearborn Lewis.

2. Nov. 25,1859 , Lynchburg, Va.

3. B. D., D. D.

4. Freedmen's School, 1865. Richmond Institute, 1883, completed Academic Course in three years. Graduated from Richmond Theological Seminary, 1889.

5. July 2, 1889, Ada F. McKenny, Richmond, Va.

6. Shady Grove Baptist Church, Orange Co., Va., about five years. Second Baptist Church, Richmond, Va., continuously since 1889.

7. 2,100 .

8. 30 years.

9. Pres. Gen. Bapt. Assoc. Va.; Member Pub. Board National Bapt. Convention, Executive Board Lott Carey For. Miss. Convention, Trustee Board Virginia Union University. Was first President Southern Aid Insurance Co. of Va. Is Vice Pres. St. Luke Penny Savings Bank. Represented Virginia in 50th. 
Anniversary of the Negroes' Emancipation, Nov., 1913, in New York State.

10. In first revival conducted alone, more than 500 converts were baptized. Gained quite a reputation a few years ago in debate with a Catholic priest of Richmond, on the subject: "Can man forgive sin?"

1. Charles Satchell Morris.

2. Sept. 26, 1865, Louisville, Ky.

3. D. D., LL. D.

4. Wilberforce University, Ohio, 1876-81. Howard University, Washington, D. C., 1886-'89. Uni. Michigan, 1893. Boston University, 1893-4. Newton Theological Seminary, 1895-'98.

5. July 7, 1898, Sadie Eugenia Waterman, Charleston, S. C.

6. Myrtle Bapt., West Newton, Mass., 3 years. Abyssinian Baptist, New York City, 6 years. Bank St. Bapt., Norfolk, Va., 1911 to date.

7. 1500 .

8. 17 years.

9. Pres. Mass. State Prohibition Convention, 1898. Won National Prize for Oratory representing Massachusetts. Opened British Chautauqua. Asst. Secretary Nat. Rep. Convention, 1892.

10. Represented Newton Seminary in College temperance oratorical contest in Massachusetts, won first prize, $\$ 25$. Represented Massachusetts in National contest at Pittsburg in 1897, won first prize, $\$ 75$.

1. Philip Fisher Morris.

2. Heathsville, Northumberland Co., Va.

3. A. M., D. D.

4. Howard University, Washington, D. C. Graduated 1880.

5. 1882, Angelina Taliaferro, Lynchburg, Va.

6. Lynchburg, Va.: Court St. Baptist Church, 17 years; Eighth St. Baptist Church, 12 years.

7. Not pastoring now.

8. 27 years. 
9. 33 degree Mason and P. G. Master of Masons of Va.

10. Dean of Theological Department Shaw University, Raleigh, N. C., for three years, also Prof. Logic, Ethics and Economics.

1. Jesse Waddell Patterson.

2. July 15,1870 , New Kent C. $H$.

3. B. D.

4. Richmond Theological Seminary (also took academic course there), finished 1896.

5. Sept. 30, 1903, Julia Ann Vivian Chiles, Louisa, Va.

6. Zion Bapt. Church, Louisa Co., Va., 8 years.

First Baptist Church Hampton, Va., 8 years.

7. 1260.

8. 18 years.

9. Cor. Sec. Norfolk Baptist Assoc., Treasurer Baptist Gen. Assoc.

10. I served on the Home Mission Field as a missionary three years during my time in school, with marked success.

1. David Nathaniel Vassar.

2. Dec. 5, 1847, Bedford City.

3. A. B., A. M., D. D.

4. A. B. \& A. M., Colgate, Hamilton, N. Y. -1877 class. D. D., Shaw University, Raleigh, N. C., 1892.

5. June 21, 1882, Alice Walker Kinckle.

6. Louisa First Baptist Church, 32 years.

7. About 600 .

8. About 40 years.

9. Moderator Shiloh Baptist Assoc. 2 years; Treasurer For. Miss. Convention, 10 years. Grand Chief Templar of Va. 5 years. (Good Templars.)

10. Taught 25 years in Richmond. Sent by Southern Baptist Foreign Mission Convention (col.) in 1892 to Africa to overlook the mission fields.

1. Ellis Watts.

2. Sweetbriar, Amherst, Va. • 
3. B. D., D. D.

4. Richmond Institute, Richmond Theological Seminary, 1875-80, 1891-4.

5. 1880, Octavia Brown, Richmond, Va.

6. First Baptist, Louisa. . . . Petersburg, 21 years. Present charge is a new church.

7.

8. 44 years.

9. Seven years president General Assoc. (col.), Moderator Va. Lebanon Baptist Assoc. at present.

10. My present charge came out of the Howard St. Church; eleven years ago. Put up a building at a cost of $\$ 22,000$, present debt on building, $\$ 10,000$.

\section{Presbyterian.}

1. James Richard Barrett.

2. Early 60's, Danville, Va.

3. A. M., S. T. B.

4. Graduate of Hampton, 1879; of Lincoln University, $\mathrm{Pa}$., 1887 ; and of the Seminary, 1894.

5. Widower.

6. Central Pres. Church, Lynchburg, Va., 11 years; in this county, Amelia, 9 years ( 3 churches).

7. One has 52, the other, 109.

8. 20 years.

9.

10. Teaching 27 years-Primary to College grades. Founder of Danville Industrial High School.

1. William Edward Carr.

2. Oct. 10, 1854, Baltimore, Md.

3. A. M., D. D.

4. Graduate of College Dep't, Lincoln University, Pa., 1877, Theological Department, 1881.

5. Dec. 26, 1882, Ruth R. J. Fisher, Washington, D. C.

6. Central Presbyterian, Lynchburg, Va, 2 years.

Holbrook St. Presbyterian, Danville, Va., 23 years next August. 
7. 140 .

8. 33 years.

9. Have represented my Presbytery three different times in General Assembly.

10. Have been moderator of Synod; and moderator of Presbytery several times.

1. Lilburn Liggins Downing.

2. May 3, 1862, Lexington, Va.

3. A. B., S. T. B., A. M., D. D.

4. Lincoln University, Pa., 1884-1894.

5. June 10, 1888. Lottie J. Clinton, daughter of Bishop J. J. Clinton, A. M. E. Z. church.

6. Fifth Avenue Presbyterian Church, July, 1894, and so for twenty years, Roanoke, $\mathrm{V}_{2}$.

7. 150 .

8. Twenty years.

9. Grand Master of District Grand Lodge, No. 15, Virginia, 4 years. G. U. O. O. F. Serving fourth term as President Patriarchal Union covering Delaware, Maryland, D. C. and Virginia.

10. At present Chaplain in Chief and member of grand Staff Council Patriarchies of America. G. U. O. of O. F., Rank Colonel. Am and have been for sixteen years the only colored member of Republican City Committee. Deputy Grand Master M. W. Grand Lodge of A. F. \& A. M. of Virginia. The Presbytery of Southern Va. honored me twice as its moderator, and elected me three times as Commissioner to the General Assembly, at Los Angeles, Cal., Warsaw, Ind., and in 1913 to the historical Assembly at Atlanta, Ga. I was the first permanent Sabbath-school missionary in this state under the Board of Publication and S. S. work of our General Assembly.

1. James E. Harper.

2. Jan. 4, 1875, Abbeville, S. C.

3. S. T. B.

4. A. B., A. M., Lincoln University, Pa.; College Class, 1895. Tlieology, 1898. 
5. 1903, Mary L. Baptist, a school teacher of West Chester, $\mathrm{Pa}$.

6. Athens, Ohio, 1 year. Carmel Presbyterian church, Cincinnati, Ohio. 12 years. First Presbyterian (col.), Richmond, Va., 2 years.

7. 121.

8. 15 years.

9. In demand for addresses, both political and fraternal.

10. Organized and founded the first and only Colored Presbyterian church in the state of Ohio.

1. John Grandison Harris.

2. Cumberland $\mathrm{Co}$., Va.

3. None.

4. Howard University, Washington, D. C.. Theological and Literary Courses. Oct., 1879, to April, 1886. (Theol. 3 years, Literary 4 years.)

5. Nov. 22, 1888, H. L. Peck: June 19, 1906, S. B. Hill.

6. French Broad Presbyterian church, Henderson Co.. N. C., 1 year. . . . . Central Presbyterian Church, Petersburg, Va., 15 years.

7. 50 .

8. 28 years.

9. None.

10. Have been successful in reviving three dead churches. I have given and raised scholarships for the education of 128 boys and girls since 1886 .

1. William Henry Sheppard.

2. March 8, 1865, Waynesboro, Va.

3. D. D., F. R. G. S.

4. Hampton Normal Institute: Stilman Theological Seminary, Tuscaloosa, Ala.

5. Feb. 21, 1894, Lucy Jones Gantt.

6. Twenty years in Luebo, Congo Free State, Central Africa.

7. 140. 
8. $11 / 2$ years in Louisville, Ky.

9.

10. "Sent to Louisville by Ex. Com. Home Missions, Southern Presbyterian Church, to work among his own race. His life as a missionary reads like a romance. Honored by Queen Victoria for Aiscoveries made in Africa." Courier Journal, June 22, 1913.

1. William Lawson Smith.

2. Feb. 14, 1849, Bowling Green, Va.

3.

4. B. A. Collegiate Department, Lincoln University, Pa., 1883. Theology under Dr. Hoge, Richmond, Va.

5. April, 1890, Martha T. Miles, public school teacher, Richmond, $\mathrm{Va}$.

6. Mt. Zion Presbyterian Church, Ashland, 10 years. -. . Harper Memorial Church, 1 year. Mt. Hermon, Chula. Va.

7.

8. 21 years.

9. \& 10.

EPISCOPAL.

1. Samuel Whittemore Grice.

2. July 8, 1880, Plantersville, Georgetown Co., S. C.

3. B. D.

4. Graduated St. Augustine's Collegiate Course at Raleigh, N. C., 1901. St. Augustine's Normal and Collegiate Institute. Graduated from the Bishop Payne Divinity School, Petersburg, Va. 1904.

5. June 28, 1905, Susan M. Rhone, Raleigh, N. C.

6. Church of the Epiphany, Spartanburg, S. C.; 5 years. New Warden of Bishop Payne Divinity School, Petersburg, Va.

7. Have no regular church.

8. 9 years.

9. 
10. Graduated as Valedictorian of class. Secretary of the Convocation among Colored people in South Carolina, 2 years. Now the only colored Professor in the Divinity School, Petersburg.

1. David Jonathan Lee.

2. Sept. 15,1880 .

3.

4. The Mico Training College, Jamaica, B. W. I., 1900'03. Lincoln University, Ill., 1905. Bp. Payne Divinity School, Petersburg, 1906-'09.

5.

6. Grace P. E. Church, Norfolk, Va., 1909-1914, and Tunly Chapel, Berkely, Va., July 1912-1914.

7. 205.

8. 6 years.

9. \& 10.

1. Joseph Fenner Mitchell.

2. Jan. 9, 1853, Franklinton, N. C.

3.

4. Christian College, Franklinton, N. C., 1879-1882. The Bishop Payne Divinity School, P. E. Church, 1886-1889, Petersburg, Va.

5. June 7, 1874, S. A. Winston.

6. St. Stephen's Church, Petersburg, Va. 1886-1897. . . . Alexandria, Va., 7 years.

7. 31 .

8. 25 years.

9. Preached baccalaureate sermon to class 1892 of the Va. N. \& C. L. I.

10. Presbyter of the church.

1. Sandy Alonzo Morgan.

2. July 15,1887 , Richmond, Va.

3. 
4. St. Paul's School, Lawrenceville, Va., 1903-'05. Bishop Payne Divinity School, Petersburg, Va., 1905-'09.

5. Feb. 2, 1911, Mary E. Smith.

6. St. Margaret's, Orange, Va., 1 year. . . . . Portsmouth, Va.

7. 80 .

8. 5 years.

9. \& 10. No.

1. James Solomon Russell.

2. Dec. 20, 1857, Palmer's Springs. Va.

3.

4. Hampton Normal and Agricultural Institute, Hampton, Va., 1874-5 and 1877-8. St. Stephen's Normal School and the Branch Theological School of Virginia, Petersburg. Va., 1878-82.

5. Dec. 20, 1882, Virginia M. Morgan, Petersburg, Va.

6. St. Paul's Church, Lawrenceville, since 1882. GeneraI missionary in Brunswick and Mecklenburg counties.

7. 220.

8. Since March 16, 1882.

9. Ordained Deacon March 9, 1882, advanced to the Priesthood Feb. 9, 1887, appointed Archdeacon for colored work in the Diocese of Southern Virginia in 1893.

10. Fourider and principal of St. Paul Normal and Industrial School.

1. Charles Louis Somers.

2. Jan. 3, 1875, Washington, D. C.

3. None.

4. St. Paul Normal and Industrial School, 1896-97. Howard University 1897-1901. Bishop Payne Divinity School, 1901-'04.

5. Dec. 27, 1904, Frances Ellen Harper.

6. Meade Memorial Chapel, Alexandria, Va., 3 months. St. Paul's Church, Gordonsville, 2 months. Richmond, Va.

7. 160.

8. 10 years. 
RELIGIOUS DEVELOPMENT OF THE NEGRO

9. On Board of Trustees Negro Reformatory Association of Va. President Interdenominational Ministerial Union of Richmond, Va.

10. I had to work to support myself in school with only the assistance of a widowed mother.

\section{AFRICAN METHODIST EPISCOPAL CHURCH.}

1. Israel Lafayette Butt.

2. May 3, 1846, Norfolk Co., Va.

3. D. D.

4. Richmond Institute, 1878-1880. Hampton Institute, Theological Department, 1883-1887. Correspondence Course, Payne Seminary, Selma, Ala., 5 years.

5. May 29, 1911, Marie Church, Eastville, Va. (second wife).

6. St. James Mission, Norfolk, Va., one year.

Allen Chapel, one year, present charge.

7. 330 .

8. 37 years.

9. Delegate to General Conference, 1900, Columbus, Ohio; 1904. Chicago. Justice of the Peace, 6 years, Constable, 3 years, Norfolk Co.

10.

1. Nornnan Wesley Brown.

2. Oct. 20, 1875, High Point, Md.

3.

4. Morgan College. Balto., Md.: Howard Lniversity, Washington, D. C., Classes of 1896 and 1900.

5. Nov. 7, 1900, Sophia Banks.

6. Patuxtant, Md., 2 years. . . . . Newport News, Va., 4 years.

7. 385 .

8. 19 years.

9. President Norfolk A. M. E. Preachers' Meeting; Pres. Negro Business League, Newport News; member Ex. Com. Kittrell College, Kittrell, N. C.; Delegate to International C. E. Conventions Atlantic City and Los Angeles. Alt. Del. to 
Gen. Conf. A. M. E. church in 1912. Chm'n Com. on Elders' Orders, Va. Conf. A. M. E. church.

10. Mason, Odd Fellow, and Pythian. Wrote thesis on "Immortality of the Soul" and Morris Brown College, Atlanta, Ga., conferred title of D. D. on me.

1. Oscar Theodore Day.

2. July 29, 1865, East Liberty, Ohio.

3. D. D.

4. Public and High schools, Cincinnati, Ohio; Correspondence Course in Theology, Howard University.

5. July 6, 1893, Jennie Elnora Jackson, Xenia, Ohio.

6. Sawyer Chapel, Elizabeth City, N. C. . . . . now Presiding Elder, Richmond District. Va. Annual Conference. 7.

8. 17 years.

9.

10. Taught eight years in public schools of Ohio.

1. Marion E. Davis.

2. Jan. 19, 1864, Ebenezer, Miss.

3. B. D., D. D.

4. Waldern University, Nashville, Tenn., 1882-'86; Normal, University, Wilberforce, Ohio, 1888-'94, College Preparatory and Theological Courses, graduating 1894.

5. Oct. 27, 1897, Cora L. Flagg.

6. Springfield, Ohio, 4 years. . . . . Portsmouth, Va., 4 years.

7. 1186.

8. 24 years.

9. President, Stringer Academy, Friars Point, Miss., and Ward Academy, Natchez, Miss.

10. Have cleared several churches of debt, and managed a $\$ 5,000$ campaign for the Old Folks Home.

1. Edward Hughes Hunter.

2. Nov. 13, 1865, Raleigh, N. C. 
3. A. B., LL. B., LL. M., D. D.

4. Public schools, Raleigh; Literary and Classical Courses, Lincoln Univ., Pa., 1883-85; Law Course, Howard Univ., Washington, D. C., 1892, 1893, 1896; Theology, Howard Univ., 1902-3.

5. 1889, Mary L. Russell ; 1903, Jennie M. Spears, Washington, D. C.

6. A. M. E. Church. Sandy Springs, Md., one year. . . . . St. John's Norfolk, Va. (present pastorate), three years.

7. About 1425.

8. About 12 years.

9. Accepted as the logical standard bearer in efforts of $\mathrm{Va}$. Methodists to secure official recognition. Served in Washington, D. C., as Sunday-school superintendent, president Y. P. S. C. E.; secretary of Trustee Board, etc.

10. "Spent 19 years in U. S. Government service; expert examiner of land claims for the Government. Member of the bar of District of Columbia. Fine business record and standing in Raleigh, Washington, Richmond and Norfolk. A successful teacher in North Carolina." Rev. S. S. Morrison.

1. George D. Jimmerson.

2. Oct. 4, 1849, Salem, Va.

3. D. D.

4. Colver (now Virginia Union University), 1869 and '70.

5. July 4, 1871, Emma S. Ashby.

6. Prospect, Prince Ed. Co., Va., 1 year. . . . . Emmanuel A. M. E. Church, Portsmouth, Va., 4 years. Presiding Elder 13 years.

7. 3,000 members in District.

8. 43 years.

9. None.

10. I was a slave.

1. Samuel Solomon Morris.

2. Sept. 2, 1878, Portsmouth, Va.

3. A. B., B. D. 
4. Morris Brown College, Atlanta, Ga., 1902-05: Gammon Theo. Seminary, Atlanta, Ga., 1899-1902.

5. April 4, 1912, Mary Henrietta Lawson, Danville, Va., teacher and State Normal Graduate.

6. West End, Atlanta, Ga., 1901-03. . . . . Richmond, Va., Third Street, from 1911 to date.

7. 400 .

8. 13 years.

9. Director Grand Fountain United Order True Reformers, Member Grand Lodge Masons of Va.

10. Supt. Ind. Dept. Morris Brown College, 1903-05. State Supt. Va. Allen C. E. League, Member Gen. Conf. A. M. E. Church 1912. Member Miss. Board A. M. E. Church. Pursuing Post Graduate course for Ph. D. degree, Va. Lnion University.

1. Alfred J: Nottingham.

2. Aug. 18, 1868, Eastville, Va.

3. D. D.

4. Hampton Institute, May, 1891. Theological Correspondence Course, Morris Brown College, Atlanta, Ga.. 1908.

5. Sept. 6, 1893, Mattie J. C. Robins, Eastville, Va.

6. Mt. Zion A. M. E. Church, Norfolk Co., 3 years. . .' . Hampton, 3 years.

7. 200.

8. 18 years.

9. Secretary A. M. E. Conference, 8 years; member A. M. E. Gen: Conf., Kansas City, Mo., 1912, and First Asst. Recording Sec.

10.

1. James Woods Sanders.

2. Near Nashville, Tenn.

3. D. D.

4. Kittrell College, Kittrell, N. C.

5. Oct., 1899, Corintha May Bolden.

6. Colorado Springs, 1885. . . . . (Preached in North 
Missouri, Kansas and Colorado Conferences.) Brown's A. M. E. Church, Smithfield, Va., since 1910.

7. 250.

8. 29 years.

9. Trustee Wilberforce University, Ohio.

10. Have added 125 members to my present church. Have mission attached.

1. George Claudius Taylor.

2. July 12. 1862, Georgia.

3. D. D.

4. Payne College, Augusta, Ga., finished 1888; Gammon Theological Seminary, Atlanta, Ga., finished 1892.

5. Widower.

6. A. M. E. Church, Athens, Ga., 3 years. . . . . Oceana. Va. (present charge) three years.

7. 560 .

8. 26 years.

9. Royal High Priest, Impr'd Ancient Order Children of Israel (a benevolent institution), with 19,000 members.

10. Have been called the church builder and money raiser.

1. John Chambers Williams.

2. July 9. 1853, Pittsborough, N. C.

3. B. D.

4. Shaw University, Raleigh. N. C., 1878 and 1879. Howard University, Washington, D. C., 1880 and 1883.

5. April 23, 1885, J. R. St. Clair, Wytheville, Va.; Nov. 3, 1897, Carrie G. Johnston, Wytheville, Va.

6. Danville Mission, one year. . . . . Presiding Elder, Norfolk District, five years.

7. 3301 members in District.

8. 38 years.

9.

10. Founder and Chief Shepherd of the Christian Helping Hand Association of the World, incorporated 1905. 